Faculdade de Economia, Administração, Contabilidade e Ciência da Informação e Documentação - FACE

Programa de Pós-Graduação em Administração - PPGA

Miyuki Abe

\title{
Inovação em Serviços em uma Unidade de Negócio de uma Empresa Pública
}

Brasília - DF 


\section{Miyuki Abe}

\section{Inovação em Serviços em uma Unidade de Negócio de uma Empresa Pública}

Monografia apresentada ao Programa de PósGraduação em Administração (PPGA) da Faculdade de Economia, Administração, Contabilidade e Ciência da Informação e Documentação (FACE), da Universidade de Brasília, como requisito parcial à obtenção do grau de Especialista em Orçamento e Finanças.

Orientador: Prof. Dr. Eduardo Raupp de Vargas

Brasília - DF 


\section{Miyuki Abe}

\section{Inovação em Serviços em uma Unidade de Negócio de uma Empresa Pública}

Brasília, junho de 2009

Monografia aprovada por:

Eduardo Raupp de Vargas (Orientador)

Universidade de Brasília, Programa de Pós-Graduação em Administração 
Aos meus filhos Tiago e Léo, que me inspiram e motivam a buscar desenvolver-me melhor como mãe, ser humano, profissional e aprendiz.

Ao meu marido, Paulo Hilton, pelos nossos filhos, por tudo que representa na minha vida e pelo seu amor incondicional. 


\section{AGRADECIMENTOS}

Ao meu orientador, Dr. Eduardo Raupp, pelos ensinamentos que me possibilitaram um novo olhar sobre inovação em serviços e valores púbicos.

Ao meu marido e meus filhos pela compreensão, pelo incentivo e pelo apoio em todos os momentos.

À minha mãe, o meu exemplo de vida, pela sua orientação e apoio incondicional.

À Silvia Regina, pela amizade e pela troca de aprendizado sobre inovação em serviços.

Ao Fernando Travassos e ao André Gustavo, pela contribuição na revisão desta monografia.

À Neide e ao Ivo, pela amizade, parceria e dedicação à SUNAF.

Aos colegas da SUNAF, pela contribuição na pesquisa.

Ao SERPRO pela oportunidade do aprendizado. 
“O rico histórico de realizações do passado impõe a nós uma enorme responsabilidade no sentido de continuar aprimorando a gestão financeira, orçamentária e contábil da União”.

Murilo Portugal - Secretário do Tesouro Nacional (1992-1996) 


\section{RESUMO}

Verifica-se, no mundo, um acelerado processo de globalização, caracterizado pela desregulamentação e internacionalização, os quais contribuem para uma maior competição dentro das economias nacionais, principalmente em atividades de serviços até então relativamente protegidas. O setor de serviços, considerado, durante muito tempo, essencialmente não inovador, apresenta-se como um setor bastante ativo em implementação de inovações, respondendo, atualmente, por cerca de dois terços do PIB das principais economias mundiais. Este fenômeno verifica-se especialmente nos serviços empresariais e nos serviços baseados em tecnologia de informação e comunicação (TIC), os chamados serviços intensivos em conhecimento (SICs), considerados os indutores de crescimento econômico. Neste contexto, o presente estudo foi desenvolvido com o objetivo de identificar as especificidades do processo de inovação em serviços de TIC no setor público, tendo como caso de análise a Superintendência de Negócio Administração Financeira (SUNAF), uma das principais unidades de negócio de uma empresa pública brasileira - o SERPRO. O marco teórico adotado permite a análise integradora do processo de inovação, complementado por uma abordagem que enfatiza as características e atributos de práticas inovadoras do setor público. Observou-se que no núcleo da motivação da inovação está a busca pela eficiência e eficácia da gestão financeira para viabilização de políticas públicas. Identificou-se que há uma intensa interação entre cliente e fornecedor que contribui para o aumento de eficiência dos processos de negócios e para a transferência de conhecimento, com geração de novos conhecimentos. Apesar da importância do processo de inovação em serviços, nota-se a ausência de um processo corporativo que institua um modelo de gerenciamento de inovação, capaz de transformá-lo em instrumento indutor de uma estratégia de inovação sustentável, visando potencializar o resultado empresarial.

Palavras-chaves: Inovação em serviços; Inovação no setor público; Inovação em serviços baseados em tecnologia da informação e comunicação (TIC); Serviços intensivos em conhecimento (SIC). 


\section{LISTA DE FIGURAS}

Figura 1 - Composição do setor de serviços da economia brasileira, segundo atividades classificadas em SIC e demais atividades do setor (Brasil, 2001) 22

Figura 2 - Um modelo de quatro dimensões da inovação em serviços. 28

Figura 3 - O produto como vetores de características e de competências colocadas em correspondência . 31

Figura 4 - Organograma da SUNAF. 43

Figura 5 - Diagrama de procedimentos da coleta e análise dos dados. 48 


\section{LISTA DE QUADROS}

Quadro 1 - Dimensões do processo de inovação no setor público 36

Quadro 2 - Lista de atributos presentes num projeto inovador no setor público ......38

Quadro 3 - As principais características de uma pesquisa qualitativa. 42

Quadro 4 - Fontes de evidências: pontos fortes e pontos fracos. 46

Quadro 5 - Blocos temáticos para coleta de dados.

Quadro 6 - Características e atributos excluído da análise 50

Quadro 7 - Descrição dos serviços de TIC pesquisados 55

Quadro 8 - Demonstrativo de patrocinadores e clientes dos serviços 55

Quadro 9 - Demonstrativo da entidade identificadora da necessidade de serviço de TIC 56

Quadro 10 - Demonstrativo dos principais objetivos por tipo de serviços de TIC ....58

Quadro 11 - Demonstrativo do público alvo por serviços de TIC 61

Quadro 12 - Principais características finais dos serviços de TIC .64

Quadro 13 - Características técnicas dos serviços 67

Quadro 14 - Competências mobilizadas para implementação dos serviços . 71

Quadro 15 - Classificação dos serviços por modelo de inovação. 74

Quadro 16 - Práticas inovadoras de gestão pública em serviços de TIC. 77

Quadro 17 - Grau de aderência dos serviços de TIC aos atributos de inovação em gestão pública 


\section{LISTA DE SIGLAS}

CMM - Capability Maturity Model

CPR - Contas a Pagar e a Receber

BACEN - Banco Central do Brasil

BB - Banco do Brasil

BGU - Balanço Geral da União

DAS - Documento de Arquitetura do serviço

DV - Documento de Visão

DPI - Dívida Pública Interna (DPI)

DW - Data Warehouse

e-Car - Sistema para Controle, Acompanhamento e Avaliação de Resultados

e-Gov - Governo Eletrônico

EGTI - Estratégia Geral de Tecnologia da Informação

ETL - Extract, Transform and Load

FPE - Fundo de Participação dos Estados

FPM - Fundo de Participação dos Municípios

FTP - File Transfer Protocol

GRU - Guia de Recolhimento da União

$\mathrm{HW}$ - hardware

IBGE - Instituto Brasileiro de Geografia e Estatística

ITIL - Information Technology Infrastructure Library

KIBs - Knowledge Intensive Business Services

MF - Ministério da Fazenda

OECD - Organization for Economic Co-operation and Develpment

PAS - Pesquisa Anual de Serviços

PDTI - Plano Diretor de Tecnologia da Informação

PGFN - Procuradoria-Geral da Fazenda Nacional

PIB - Produto Interno Bruto 
PGPS - Processo de Gerenciamento de Projetos do SERPRO

PMBOK - Project Management Body of Knowledge

PSDS - Processo SERPRO de Desenvolvimento de Soluções

PSGS - Processo SERPRO de Gerenciamento de Serviços

PSS - Programa SERPRO de Segurança

P-SIC - Professional SIC

P\&D - Pesquisa e Desenvolvimento

RPC - Reverse Product Cycle

RSFN - Rede do Sistema Financeiro Nacional

SERPRO - Serviço Federal de Processamento de Dados

SIAFEM - Sistema Integrado de Administração Financeira para Estados e Municípios

SIAPE - Sistema Integrado de Administração de Recursos Humanos

SIASG - Sistema Integrado de Administração de Serviços Gerais

SIC - Serviço Intensivo em conhecimentos

SPB - Sistema de Pagamentos Brasileiro

STN - Secretaria do Tesouro Nacional

STA - Sistema de Transferência de Arquivos

STR - Sistema de Transferência de Reservas

SUNAF - Superintendência de Negócio Administração Financeira

SVPC - Sistema de Viagens e Prestação de Contas

SW - Software

TN - Tesouro Nacional

T-SIC - Technological SIC

TCU - Tribunal de Contas da União

TIC - Tecnologia da Informação e Comunicação 


\section{SUMÁRIO}

1. INTRODUÇÃO ................................................................................................ 12

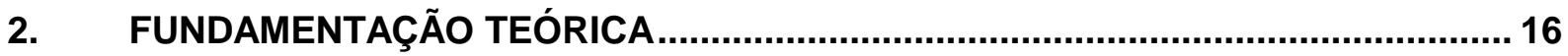

2.1. O setor de serviços ................................................................................ 16

2.1.1. As especificidades dos Serviços e os impactos na análise inovação de serviços.... 18

2.1.2. Serviços Intensivos em Conhecimento e Tecnologia de Informação e Comunicação20

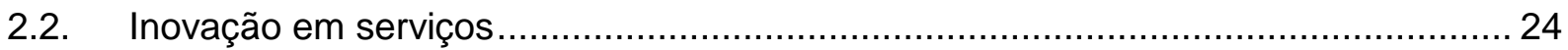

2.2.1. Teorias de Inovação em serviços .................................................................... 25

2.2.2. Modelo baseado em quatro dimensões proposto por Bilderbeek et al. ......................27

2.2.3. Modelo do ciclo reverso do produto ...................................................................... 29

2.2.4. Modelo único de representação das diversas formas de inovação - uma abordagem integradora de inovação ............................................................................... 31

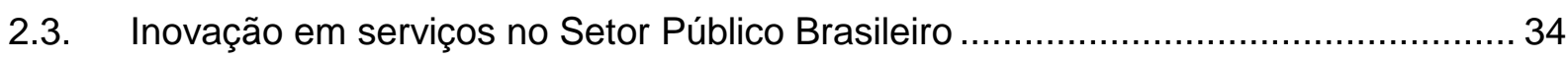

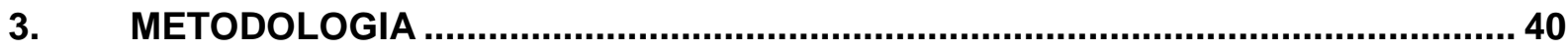

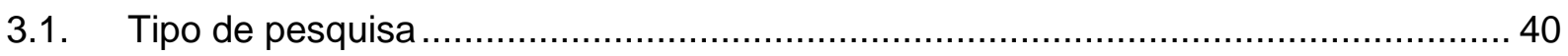

3.2. População e amostra .............................................................................. 42

3.2.1. Superintendência de Negócios Administração Financeira (SUNAF) .........................43

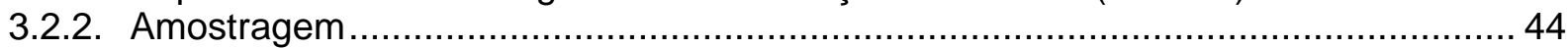

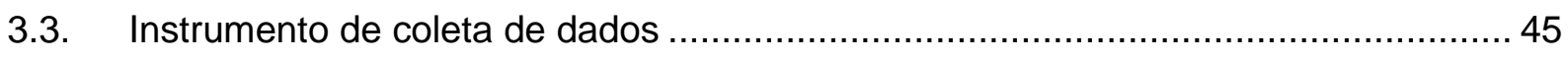

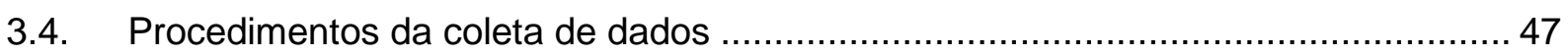

3.5. Análise dos Dados ......................................................................... 49

4. APRESENTAÇÃO E ANÁLISE DOS RESULTADOS ....................................... 52

4.1. Descrição dos serviços de TIC selecionados ................................................... 52

4.2. Origem das inovações em serviços de TIC ..................................................... 55

4.3. Caracterização da inovação em serviço de TIC ................................................. 62

4.3.1. Serviços de TIC - quanto a características de serviço, o seu valor de uso ...............62

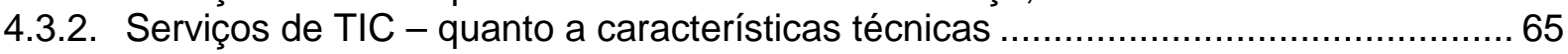

4.3.3. Competências do prestador de serviço de TIC e do cliente...................................69

4.3.4. Classificação das inovações em serviços de TIC ............................................... 73

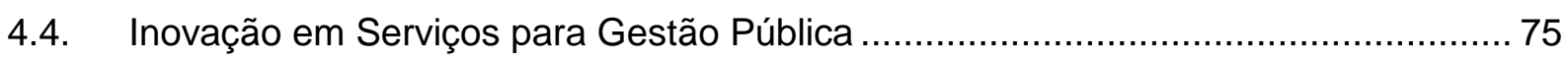

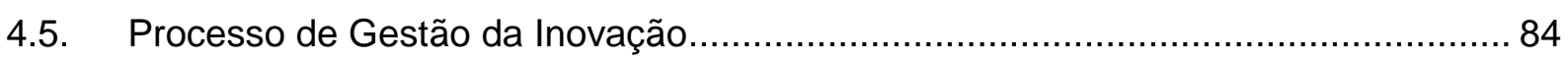

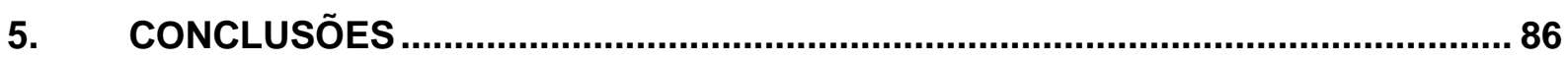

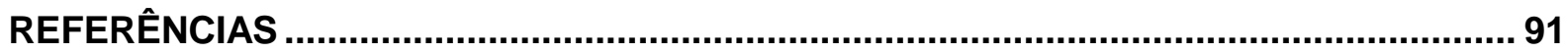

APÊNDICE A - ROTEIRO DE ENTREVISTA.......................................................... 94 


\section{INTRODUÇÃO}

Segundo Miles (2007) e Vargas (2002), verifica-se um acelerado processo de globalização, caracterizado pela desregulamentação e internacionalização dos mercados, os quais contribuem para uma maior competição dentro das economias nacionais, principalmente em atividades de serviços até então relativamente protegidas. Por conta disso, grandes empresas apostam na diversificação e em alianças, de várias formas, inclusive com seus rivais, buscando cooperar para sobreviver num mercado altamente competitivo.

Neste cenário, o setor de serviços considerado, durante muito tempo, essencialmente não inovador, apresenta-se como um setor bastante ativo em implementação de inovações, especialmente nos serviços empresariais e nos serviços baseados em tecnologia de informação e comunicação (TIC).

Freire (2006) e Kon (2007) destacam o aumento da relevância dos serviços no contexto do desenvolvimento econômico e social, particularmente, dos serviços baseados em conhecimento, considerados os indutores de crescimento econômico. Segundo Miles (2007), atualmente, o setor de serviços é considerado como um dos setores de maior crescimento na economia contemporânea, respondendo por cerca de dois terços do PIB das principais economias mundiais. No Brasil, segundo o Instituto Brasileiro de Geografia e Estatística (IBGE, 2008), em 2007, o setor de serviços representou $56,5 \%$ do Produto Interno Bruto (PIB) nacional medido a preços de mercado.

O ritmo acelerado e contínuo das descobertas científicas e tecnológicas, incrementado, principalmente, pelo advento da tecnologia de informação e comunicação, contribui, segundo diversos autores, para acelerar ainda mais essa mudança. Cada vez mais, as empresas investem alto volume de recursos para atividades inovadoras, cujo ciclo de vida é cada vez mais curto. Neste cenário, o modelo fordista de produção, vigente até então, demonstra-se não mais eficiente e efetivo para atender às demandas por bens e serviços dos clientes.

Porém, conforme Gallouj (2007) e Miles (2007), o volume de literatura, pesquisas e estatísticas realizadas sobre inovação em serviços ainda não são representativas, considerada a importância do setor de serviços, existindo diversos temas ainda a ser abordados e aprofundados. O Brasil não é diferente neste sentido. 
Nesta perspectiva, Kon (2007) chama atenção para a relevância do papel do conhecimento na execução dos serviços, ressaltando que as principais inovações relacionadas ao processamento de informação dizem respeito aos procedimentos, mais do que a instrumentos ou maquinarias. Esses procedimentos se referem à padronização, informações arquivadas, bases de dados consistentes e armazenamento de informações. A autora destaca que a compreensão da dinâmica da atividade inovadora, no setor de serviços, pode ser instrumento para ampliar os métodos de quantificação e administração das inovações, bem como, conduzir a um entendimento da dinâmica geral das economias baseadas no conhecimento.

Nesta nova economia, o conhecimento é a vantagem competitiva das empresas, onde a aprendizagem é o principal processo e o conhecimento tácito, o principal recurso. Conforme citado por Vargas,

\footnotetext{
...haveria uma nova divisão setorial da atividade produtiva que confere ao setor de serviço um caráter dinâmico, compreendido como sua capacidade de inovar, de gerar aumentos na produtividade e de gerar emprego e renda, capaz de coloca-lo em papel preponderante - ou no mínimo, equivalente em relação ao da indústria (VARGAS, 2002, p. 12).
}

Dessa forma, as atenções se voltam para os serviços empresariais intensivos em conhecimento, num contexto que vem sendo denominado, segundo Vargas (2002), por vários autores como o de uma "economia do aprendizado". Conforme o autor, "um novo paradigma surge, estabelecendo um novo conjunto de padrões institucionais (culturais, sociais, legais, econômicos etc), técnicos e organizacionais capazes de impulsionar um novo ciclo de crescimento econômico" (VARGAS, 2002, p.11).

Acentua-se, assim, a necessidade de uma melhor compreensão do processo de inovação em serviços, dada a centralidade destas atividades. Diante deste cenário, a presente monografia aborda o tema inovação em serviço de TIC, numa empresa pública. Para tanto, propõe-se como problema de pesquisa a seguinte questão: como caracterizar o processo de inovação em serviços de TIC numa unidade de negócio de uma empresa pública, especializada em serviço de TIC?

O estudo tem como objetivo geral identificar e caracterizar o processo de inovação em serviços de TIC numa unidade de negócio de uma empresa pública, a luz de teorias de inovação em serviços selecionados nesta pesquisa. Para atingir este propósito, foram adotados os seguintes objetivos específicos: i) discutir os 
conceitos e especificidades de serviços e inovações em serviços; ii) analisar os aspectos diferenciais dos serviços intensivos em conhecimentos e tecnologia de informação e comunicação; iii) caracterizar as inovações em serviços de TIC implementados pela SUNAF; e iv) analisar o processo de gestão da inovação em serviços de TIC na SUNAF.

Como procedimento de pesquisa optou-se pelo estudo de caso da Superintendência de Negócios Administração Financeira (SUNAF), uma das unidades de negócios do Serviço Federal de Processamento de Dados (SERPRO), que presta serviços especializados em TIC no segmento de administração financeira do setor público, cujos principais clientes são a Secretaria do Tesouro Nacional (STN) do Mistério da Fazenda (MF) e o Tribunal de Contas da União (TCU).

A relevância deste desta pesquisa está na oportunidade de adicionar o entendimento das especificidades de inovação em serviços de TIC, de uma superintendência de negócio de uma das maiores, senão a maior empresa pública brasileira especializada em serviço de TIC, responsável pelo desenvolvimento e produção dos principais sistemas estruturantes do Governo Federal. A importância do estudo focando a SUNAF está, também, no fato que a área financeira é reconhecida como a área que mais implementa inovações em serviços no mercado.

$\mathrm{Na}$ esfera de atuação da SUNAF, o projeto pode contribuir para o entendimento do seu processo de inovações em serviço, com possibilidade de gerar insumos para ações futuras para ajustar as estratégias de negócio da unidade e dos seus processos de gestão, não só da inovação, mas também dos demais processos (gerenciamento de desenvolvimento de software, gerenciamento de projetos, capacitação, gestão do conhecimento etc), propiciando o surgimento de novos serviços e a melhoria na qualidade na prestação dos serviços existentes. Para o SERPRO, o resultado da pesquisa pode gerar insumos para ações de ajuste e alinhamento das estratégias de inovação em serviços, em nível de empresa, a partir da extensão da pesquisa para demais unidades da organização, visando eficiência e efetividade na prestação de serviços em TIC para os seus clientes e usuários, que possibilitará fortalecimento da imagem e a marca SERPRO no mercado de TIC, no segmento governo. Para o setor público, a melhoria do processo de inovações em serviços do SERPRO estará beneficiando diretamente na eficiência e na efetividade dos serviços públicos baseados em TIC fornecidos por esta empresa pública.

Este trabalho está organizado em 4 capítulos, além desta introdução. No capítulo 2, fundamentação teórica, realiza-se a discussão sobre inovação no setor 
de serviços apresentando as teorias e modelos de inovação e as especificidades de serviços intensivos em conhecimento. Neste capítulo, também, discute-se as inovações em serviços no setor público. No capítulo 3, metodologia, descreve-se os procedimentos de investigação adotados, detalhando como efetivamente se processou. No capítulo 4, apresentação e análise dos resultados, descreve-se os resultados da pesquisa e realiza-se discussão dos resultados, sob a luz das teorias de inovação em serviços, e, por fim, no capítulo 5 são apresentadas as conclusões deste trabalho. 


\section{FUNDAMENTAÇÃO TEÓRICA}

Este capítulo apresenta uma análise da produção científica sobre o tema inovação em serviços, pano de fundo da investigação desenvolvida. Assim, inicialmente, serão discutidos os conceitos e especificidades de serviços e, ainda, os aspectos diferenciais do setor de serviços em relação ao setor de manufatura. Em seguida, serão introduzidos os conceitos e as características de uma categoria especial de serviços, denominada de serviços intensivos em conhecimento (SICs), cuja participação e importância na economia tem crescido significativamente nas últimas duas décadas, como demonstram Bernardes e Kallup (2007) e Freire (2006). Então, serão discutidos os conceitos e as questões que envolvem as inovações em serviços, apresentando os principais autores dedicados ao tema, detalhando as respectivas teorias e os modelos de inovações em serviços. Por último, será dedicado um espaço para apresentar as discussões teóricas relacionadas às inovações em serviços no setor público brasileiro, contexto em que se insere o objeto desta pesquisa.

\subsection{O setor de serviços}

Desde a era industrial, o desenvolvimento econômico das sociedades foi baseado essencialmente no setor manufatureiro. Assim, o setor de serviços, durante muito tempo, foi considerado como um setor de atividades residuais comparadas às demais atividades econômicas.

\footnotetext{
A literatura econômica tradicional atribui às atividades manufatureiras o papel de indutoras do desenvolvimento, para as quais se dirigiriam inicialmente o capital e a mão-de-obra acumulados como estratégia de crescimento e ampliação do retorno ao excedente do capital. A Dinâmica de transformações na estrutura produtiva, assim iniciada, se difundiria posteriormente para o setor de serviços na economia. Esse fenômeno foi amplamente comprovado nos países mais avançados, principalmente até os anos 1980 (KON, 2007, p.81).
}

Segundo Kubota (2006), historicamente o setor de serviço foi marginalizado nos estudos da economia no Brasil e em outros países. Porém, alguns acontecimentos no mundo estão mudando significativamente esse cenário. A 
Organization for Economic Co-operation and Development (OECD), em 2005, publicou que o crescimento da produtividade e o do emprego são altamente dependentes do sucesso das empresas de serviços, classificando-os como importantes agentes do crescimento econômico dos países que fazem parte da OECD.

A medida do crescimento da importância dos serviços na economia mundial, os pesquisadores e estrategistas voltaram as suas atenções para esse setor, trazendo conclusões importantes, os quais são destacados por Miles (2007): i) a visão generalizante é inadequada. As características e a dinâmica do setor estão associadas à diversidade de funções econômicas por ele desempenhadas; ii) apesar da diversidade, existem várias características comuns a todos os serviços, como, por exemplo, a documentação dos serviços ser relativamente precária se comparada ao setor industrial. Possivelmente este fato está associado à produção de funções intangíveis, diferentemente da indústria que visa produção de artefatos físicos; iii) Desmistificação de que os serviços são fracos em inovação. Esse fato se deve à crescente adoção de novas TIC no setor de serviços. O processamento de informações é decisivo para as atividades de serviços, tal como o processamento físico de materiais é decisivo para a indústria.

Se, no início do desenvolvimento econômico, as atividades de serviço foram consideradas como complementares às demais, atualmente, revelam-se em uma dinâmica de crescimento própria, sendo destaque como indutoras de crescimento econômico. Conforme mencionado anteriormente, hoje, o setor de serviços responde por cerca de dois terços do PIB das principais economias mundiais. No Brasil, segundo IBGE (2008), em 2007, o setor de serviços representou $56,5 \%$ do PIB nacional medido a preços de mercado.

Apesar da crescente participação do setor de serviços no desenvolvimento da economia mundial, as questões relacionadas ao setor de serviços permanecem pouco exploradas e necessitam ser melhor compreendidas.

Na subseção a seguir, são apresentadas as características e tendências do setor de serviços fundamentadas nos principais autores selecionados nesta pesquisa. 
2.1.1. As especificidades dos Serviços e os impactos na análise inovação de serviços

Segundo Gallouj (2007), as especificidades do serviço podem ser analisadas, principalmente, sob os seguintes aspectos:

\title{
a) A natureza intangível do serviço
}

Os produtos do serviço são, em última instância, processo e organização, consistindo de atos, protocolos de tratamento e fórmulas. Conforme o autor,

\begin{abstract}
A "topologia" dos serviços deve não somente levar em conta seu grau de materialidade ou tangibilidade, mas também o horizonte temporal da prestação (o serviço "em ato" por oposição a seus efeitos a longo prazo) e o sistema de valor, isto é, o "mundo de referência" que se inscreve de diferentes maneiras no tempo (horizonte temporal) e de matéria (grau de materialidade) (GALLOUJ, 2007, p. 8).
\end{abstract}

Esta natureza do serviço traz diversas conseqüências na análise da inovação. Ela pode contribuir para desviar o foco da análise para os componentes tangíveis da prestação de serviço, especificamente para os processos. Tal caráter traz as seguintes dificuldades: i) distinção entre inovação de produto (geralmente entendida como evolução das funcionalidades ou incorporação de novos requisitos de qualidade) e inovação de processos (orientada eficiência e/ou para redução de custos); ii) a apreciação do grau de novidade, como por exemplo, a diferença entre uma verdadeira inovação e os mecanismos tradicionais de diferenciação e de diversificação; iii) a enumeração da inovação ou da avaliação de seus efeitos econômicos.

\section{b) A prestação de serviços como uma dinâmica interativa}

As atividades de serviços são marcadas pela participação do cliente na produção da prestação de serviço, o que é denominado como co-produção. Esta interação faz-se necessária para resolver um problema de um cliente específico, sendo assim, atividades sempre diferenciadas. Esta característica remete a um segmento específico de serviços denominados de serviços intensivos em conhecimento (SICs), os quais são objeto de estudos em uma seção específica desta monografia. 
Este caráter do serviço traz diversas conseqüências teóricas sobre a inovação, quanto à sua natureza e ao seu modo de organização. Quanto à natureza, especificamente nos SICs, pode-se destacar as inovações sob medida e ad hoc, que não se enquadram nas teorias e métricas tradicionais. Quanto ao modo de organização, pressupõe o modelo de inovação interativa, centrado principalmente em grupos de projetos de geometria variável, associando diferentes profissionais da empresa e do cliente. Assim, especialmente nos SICs, o cliente é co-produto, podendo ser co-inventor, o que conduz a discussão sobre apropriação da inovação.

\section{c) Ausência de transferência de direito de propriedade}

Em serviços, nenhuma "entidade" independente (isto é, que circule econômica e independentemente do suporte do serviço) é produzida, não envolvendo estabelecimento ou troca de direitos de propriedade, como acontece com a produção de bens. Este caráter evidencia as facilidades e as dificuldades relativas a natureza do regime de apropriação da inovação nos serviços e constitui um problema para análise de inovações.

\section{d) A heterogeneidade dos serviços}

O setor de serviço possui caráter de alta diversidade e os seus produtos são extremamente variáveis de uma atividade de serviço para outra. Assim, a inovação não tem o mesmo conteúdo para um serviço de educação, financeiro ou telecomunicação. Os serviços são basicamente suportados pelo indivíduo, informação e conhecimento e, nessa realidade, não há espaço adequado para aplicação de definições tradicionais. Vale destacar que, particularmente, nos SICs, ao mesmo tempo em que se inovam, os produtos são levados a participar das inovações dos seus clientes. Neste aspecto, novamente, faz-se necessário alertar que o regime de apropriação da inovação co-produzida não está bem estabelecido, podendo levar a uma situação de dupla contabilização de inovação.

Miles (2007) corrobora com a visão de que as atividades de serviços são extremamente variadas, compreendendo desde serviços altamente especializados até as que envolvem tarefas básicas de secretariado e organização, passando por atividades mais físicas e manuais, como a limpeza industrial. Os serviços especializados são categorizados como àqueles que se baseiam em conhecimento tecnológico e nos que dependem de conhecimento de sistemas administrativos e, finalmente, em outros, os quais são denominados de SICs e são objetos da subseção 2.1.2. deste estudo. 
Ainda, segundo Miles (2007), os componentes imateriais e interatividade do serviço assumem uma proporção cada vez maior. Estas características fundamentais convidam os estudiosos a uma reflexão maior sobre a inovação nos serviços e, ainda, a uma reconciliação dos traços fundamentais das economias contemporâneas.

2.1.2. Serviços Intensivos em Conhecimento e Tecnologia de Informação e Comunicação

Nas duas últimas décadas, o desenvolvimento e a utilização de serviços e das novas tecnologias de serviços apresentam-se como os determinantes para a consecução do desenvolvimento das empresas, do governo e das economias como um todo.

Neste contexto, segundo Bernardes e Kallup (2007), as evidências sinalizam para a ocorrência de dois fenômenos relevantes nas economias contemporâneas: i) a constatação de que as economias estão cada vez mais baseadas no conhecimento e no aprendizado proporcionado pela integração social e impulsionadas também pela internacionalização; ii) o aumento verificado na participação dos setores de serviços na atividade da economia mundial. O setor de serviços vem assumindo papel cada vez mais central no desenvolvimento e na integração econômica nas economias avançadas e naquelas desigualdades de "crescimento rápido", como a Índia e a Irlanda do Norte, não só pela sua função geradora de emprego e renda, mas também pela importância crescente na sua interação com a indústria para fomento do progresso técnico e criação de riqueza social.

Entre as diversas questões relacionadas ao estudo do setor de serviços, Kon (2007) e Freire (2006) destacam o papel do conhecimento incorporado em atividade de serviço como uma das ferramentas básicas utilizadas pelos agentes econômicos para busca de maior competitividade e inserções nos mercados de trabalho internacionais. Nesse sentido, os estudos internacionais identificam um grupo de serviços cuja dinâmica de inovação é parte integrante de seu padrão de funcionamento, no núcleo dessa transformação, atuando como agentes facilitadores da disseminação do conhecimento na economia. Esses serviços vêm apresentando, 
taxas rápidas de crescimento e produzindo postos de trabalho nas economias avançadas, com alta qualificação e remuneração, os quais são denominados de Serviços Intensivos em Conhecimento (SICs) ${ }^{1}$ ou Knowledge Intensive Business Services (KIBs).

Conforme Miles (2007), os SICs podem ser agrupados em dois conjuntos:

a) Professional SICs (P-SICs): são os serviços usuários de novas tecnologias, direcionados aos conhecimentos técnicos e administrativos. São exemplos os segmentos de engenharia, design, arquitetura, marketing, publicidade, consultorias financeiras e jurídicas, pesquisa e desenvolvimento em ciências sociais e naturais, consultoria em gestão empresarial, entre outros; e

b) Technological SICs (T-SICs): são serviços focados em novas tecnologias. São exemplos as redes de informática, os serviços de telecomunicações, de pesquisa e desenvolvimento, entre outros.

As principais características dos SICs, conforme Bernardes e Kallup (2007) são: alta performance na geração de renda, divisas e valor adicionado; uma forte tendência à internacionalização das suas atividades de negócio, atuando como verdadeiros agentes facilitadores de inovação; dinâmica concorrencial baseada na disseminação de novos padrões tecnológicos e de TIC; atuam com fontes difusora da inovação; criam, produzem, desenvolvem e difundem conhecimentos para outras firmas e setores da economia; são intensivos em uso de recursos humanos de alta qualificação e remuneração; são formados por empresas desenvolvedoras e usuárias de inovações e TIC; realizam e vendem serviços de P\&D; apresentam taxas elevadas de crescimento econômico; oferecem serviços customizados e apresentam alta interação produtor-usuário (intensive-information e intensive-client).

Visando compreender os SICs na estrutura da "economia de serviços" no Brasil, Bernardes e Kallup (2007) realizaram um estudo tendo como referência a Pesquisa Anual de Serviços (PAS), elaborado pelo Instituto Brasileiro de Geografia e Estatística (IBGE) e a base do Departamento Econômico do Banco Central sobre a balança comercial de serviços, cuja fonte que permite avaliar a performance de

\footnotetext{
${ }^{1}$ Conforme Bernardes e Kallup (2007), o termo foi empregado pela primeira vez no projeto Innovation programme directorate general for telecommunications, information market and exploration of
} 
exportações e importações dos SICs. A partir do PAS, verifica-se que os SICs têm participação ativa na economia brasileira, sendo responsável pela geração de 41,8\% da receita operacional líquida e por $39 \%$ do valor adicionado do total dos serviços no país, como ilustrado na Figura 1. Nesta, chama atenção a moderada participação dos SICs em termos do total do pessoal ocupado $(14,2 \%)$ e do total de empresas $(17,5 \%)$.

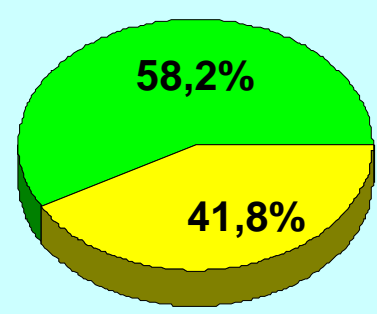

Receita operacional líquida

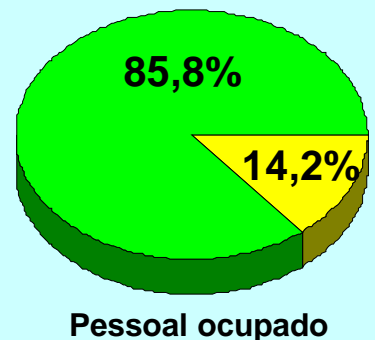

Total dos SICs

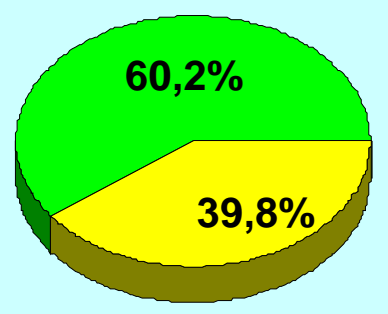

Valor adicionado

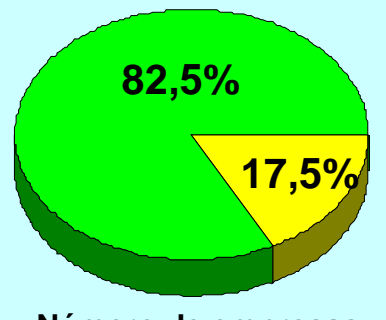

Número de empresas

Demais atividades do setor de serviços

Figura 1 - Composição do setor de serviços da economia brasileira, segundo atividades classificadas em SIC e demais atividades do setor (Brasil, 2001).

Fonte: Bernardes e Kallup (2007, p. 137).

Esta pesquisa demonstra que economicamente, a participação dos SICs é expressiva na produção de valor adicionado pelo setor, porém, esta não se traduz na capacidade para gerar empregos. Esse comportamento tem como explicação a natureza e características dos SICs, já relacionadas anteriormente, ou seja, são setores intensivos em conhecimento e inovação, geram mais valor agregando menos recursos humanos, que, por sua vez, apresentam níveis de qualificação superior aos demais setores de segmentos de serviços.

Para Kon (2007), as políticas relacionadas à tecnologia são frequentemente analisadas na literatura a partir do ponto de vista dominante da necessidade de 
gerenciar as oportunidades para a criação de externalidades positivas. Isso significa que qualquer modo potencial de intervenção por meio de serviços destinados ao desenvolvimento dessas externalidades é considerado um enfoque conjunto de produção de inovação, seja no setor público ou privado.

Segundo Miles (2007), um crescente grupo de autores passa a defender que os SICs atuam, não só como facilitadores, mas também como indutores das inovações na economia e, assim como os serviços de TIC, contribuem para o incremento da produtividade das economias. Os SICs estão entre os setores mais dinâmicos e que aceleram o crescimento da economia e sua importância está na sua capacidade de aumentar a eficiência dos processos de negócios e de transferência do conhecimento a seus clientes, podendo tornar-se parte da geração de novos conhecimentos. Dessa forma, os SICs ligados à ciência e à tecnologia desempenham papel importante na difusão de novas técnicas e sistemas para os seus clientes. Mesmo em setores tradicionais, como de contabilidade e direito, os SICs desenvolvem fortes competências em áreas ligadas à tecnologia, e podem participar das estratégias tecnológicas de seus clientes.

Kubota (2006) aponta os serviços de TIC como um importante vetor de inovação nos diversos setores da economia, destaca as empresas de informática e de consultoria dentre os SICs e, ainda, alerta que o desenvolvimento de tecnologia é fruto não apenas do conhecimento explícito, mas também do conhecimento tácito, isto é, do processo de aprendizado baseado na experiência das empresas, que interagem ativamente com outras e com o ambiente. Assim, as empresas possuem a capacidade contínua de criar novos conhecimentos a partir de capacitações específicas das empresas, em oposição à idéia de um estoque de conhecimento, como uma tecnologia particular que a empresa possua em determinado período.

$\mathrm{Na}$ mesma linha, segundo Kon (2007), a chave para o incremento da produtividade e geração de riqueza está, justamente, no gerenciamento do conhecimento ou atividade intelectual das firmas, bem como em sua interface com produtos de serviços. Dessa forma, fica claro que a base para alavancagem das competências centrais que conduzem à competitividade e ao desenvolvimento da maior parte das organizações está nas atividades de serviços baseados em conhecimento.

Assim, restam às organizações públicas e privadas a concepção de estratégias inovadoras que incorporem esses serviços indutores de desenvolvimento econômico. 


\subsection{Inovação em serviços}

De acordo com Kubota (2006), pode ser considerada como inovação qualquer mudança nos negócios pela adição de um novo elemento ou pela combinação de elementos existentes anteriormente, desde que essa mudança tenha alguma relevância e seja reproduzível.

Para Vargas (2002), partindo da definição de Dosi (1988) da inovação como uma atividade de resolução de problemas, a identificação e descrição das inovações em serviços requerem a compreensão do processo de elaboração dos serviços e do seu resultado, o produto do serviço, a caracterização do problema (causa e conseqüência) e o entendimento das soluções em curso.

Por sua vez, Gallouj (2007) define a inovação como toda mudança afetando um ou vários termos dos vetores de características (técnicas de serviços) ou de competência. Essas mudanças cobrem diferentes mecanismos elementares, tais como: evolução ou variação, desaparecimento, aparecimento, associação, dissociação ou, formatação. Elas podem ser voluntárias, isto é, intencionais, oriundas de atividades voluntárias de pesquisa e desenvolvimento, de concepção, de inovação, ou "emergentes" - ou seja, o fruto de mecanismos naturais de aprendizado.

As inovações em serviços, para Kubota (2006), têm as seguintes características: i) elas dependem menos de investimentos em pesquisa e desenvolvimento formal e mais de aquisição de conhecimento por meio de compra de equipamento, propriedade intelectual, assim como por meio de colaboração; ii) o desenvolvimento de recursos humanos é particularmente importante para os serviços, e a falta de mão-de-obra especializada pode ser gargalo para a inovação; iii) empresas menores tendem a ser menos inovativas que as maiores, mas o empreendedorismo é um fator que favorece à inovação; e iv) a proteção de propriedade intelectual é um tema que merece atenção e, especialmente, o que diz respeito a software e método de negócios.

Segundo Vargas e Zawislak (2006), as inovações em serviços podem ser classificadas em quatro tipos: i) de produto, relacionadas com o fenômeno de um novo serviço, como, por exemplo, um novo seguro, uma nova linha de crédito, uma 
nova linha de financiamento; ii) de processo, relacionadas a renovação de procedimentos para produzir e entregar o serviço. As inovações de processo podem ser subdivididas em duas categorias: no processo de produção (back office) e no processo de entrega (front office); iii) organizacional ou gerenciais, relacionadas com a introdução de novas técnicas de planejamento, gerenciamento de processos, gestão da qualidade total etc; iv) de mercado, relacionadas à descoberta de novos comportamentos mercadológicos, como, por exemplo, encontrar um novo segmento ou ingressar em outra indústria.

Os autores destacam uma outra forma de inovação, denominada de ad hoc, idenficada por Gallouj (2007), relacionada à construção socialmente interativa, cliente-provedor de serviço, para um problema particular proposto pelo cliente. Esta inovação não é diretamente reproduzível, mas sim indiretamente por meio de codificação e formalização da experiência e competência. Segundo vários autores, esse tipo de inovação é freqüente em SICs. Em toda atividade de prestação de serviços haverá espaço para esse tipo de inovação, em maior ou menor grau, dependendo da intensidade da relação usuário-produtor e a especificidade do problema a ser resolvido.

De acordo com Gallouj (2007), as características do setor de serviço e as especificidades dos serviços manifestam-se, principalmente no processo de produção de bens de capital, onde se constata que os componentes imateriais e a interatividade assumem proporção cada vez maior. Dessa forma, uma reflexão sobre a inovação nos serviços deve tanto contribuir para conciliar os traços fundamentais das economias contemporâneas, mas também para enriquecer a análise da inovação em serviços.

Para ampliar o entendimento sobre a inovação em serviços são apresentadas, a seguir, as teorias propostas pelos principais pesquisadores selecionados neste estudo.

\subsubsection{Teorias de Inovação em serviços}

Segundo Gallouj (2007), as abordagens industriais sobre a inovação apresentam ser insuficiente para a compreensão da inovação no setor de serviços. 
Essa dificuldade está diretamente relacionada à especificação de heterogeneidade presentes nos serviços, conforme caracterizadas nesse trabalho anteriormente.

Porém, Kubota (2007) registra que não existe um modelo conceitual de inovação em serviço amplamente aceito pelos autores, apresentando um modelo baseado em quatro dimensões proposto por Bilderbeek et al., o qual será detalhado posteriormente.

Para o Vargas e ZawislaK (2006) e Gallouj (2007), o debate teórico acerca da inovação em serviços é bastante novo e controverso e perspassam duas questões de absoluta relevância: i) se as organizações do setor de serviços possuem a capacidade de gerar inovações endogenamente ou se as mudanças verificadas são advindas de processos de inovação originários da indústria; ii) onde esta discussão se encontra respondida afirmativamente, se há conveniência de uma teoria específica para a inovação em serviços que trate as especificidades do processo de inovação deste setor, em relação ao da manufatura.

De acordo com Gallouj (2007), os posicionamentos frente a estas questões partem das seguintes abordagens:

\section{a) A abordagem tecnicista}

Essa abordagem está baseada na concepção, ainda predominante, de que a inovação em serviços é o resultado de inovações tecnológicas desenvolvidas no setor industrial, especialmente no setor de produção de bens de capital, Assim, os serviços teriam, então, uma atitude subordinada e dependente, de "terceiro setor". Para Gallouj (2007), essa concepção não é de todo falsa, mas a considera incompleta e incapaz de levar em conta a inovação nos serviços em toda sua diversidade e especificidade, chamando a atenção que foram os serviços que, principalmente, adotaram as tecnologias, especificamente as TICs.

Para Vargas e Zawislak (2005), esse enfoque está fortemente calcado nas mudanças provocadas pela ampla informatização em vários serviços, como por exemplo, a adoção de caixas eletrônicos, no caso dos serviços bancários, e a adoção das chamadas TICs. Os autores apresentam o modelo do "ciclo reverso do produto" como um modelo que se mostrou adequado para uma análise de difusão tecnológica nas empresas de serviços. 


\section{b) Para além das abordagens tecnicistas}

De acordo com Gallouj (2007), diversos trabalhos apontam que é possível contornar o viés tecnológico anteriormente destacado e, ainda, acentuar as formas específicas da inovação nos setores particulares de serviços ou produzir análises ou teorias locais da inovação em serviços. Assim, o autor, propõe uma leitura mais geral que possa reportar a inovação tecnológica e não-tecnológica, tanto nos serviços como nos bens, integrando-os definitivamente em uma única teoria da inovação. Segundo, Vargas e ZawislaK (2006), esta abordagem integradora deve considerar, necessariamente, uma inovação que envolve características genéricas, cuja ênfase recairá sobre peculiaridades da manufatura ou dos serviços, de acordo com a intensidade da relação usuário-produtor verificada no mercado específico em análise.

Esta convergência descreve a passagem de uma economia dos serviços para uma economia da "relação de serviço", enquanto modo de coordenação entre agentes econômicos. Assim, com base nas características do produto (bens e serviços), adaptadas às especificidades dos serviços, Gallouj (2007) propôs um modelo único de representação das diversas formas de inovação, possibilitando uma abordagem integrada de bens e serviço.

Os modelos apresentados, nesta sub seção, serão detalhados, nos itens a seguir, sob ótica, principalmente, da sua aplicabilidade na análise de inovação em serviços e, especificamente, de TIC que é objeto desse projeto de monografia.

2.2.2. Modelo baseado em quatro dimensões proposto por Bilderbeek et al.

No que diz respeito aos SICs, o modelo baseado em quatro dimensões proposto pelo Bilderbeek et al. é apresentado pelo Kubota (2007), conforme ilustrado na Figura 2.

As quatro dimensões do modelo proposto pelo Bilderbeek et al. (1998 apud KUBOTA, 2007, p. 217) estão detalhadas a seguir:

- Novo conceito do serviço: na primeira dimensão as inovações em serviços possuem características próprias e distintas em relação à manufatura, porém há autores que entendem que o serviço simplesmente complementa o da manufatura. Normalmente, os novos produtos são intangíveis; assim, é mais 
relevante tratar uma nova idéia ou conceitos, o que é uma tarefa mais complexa.

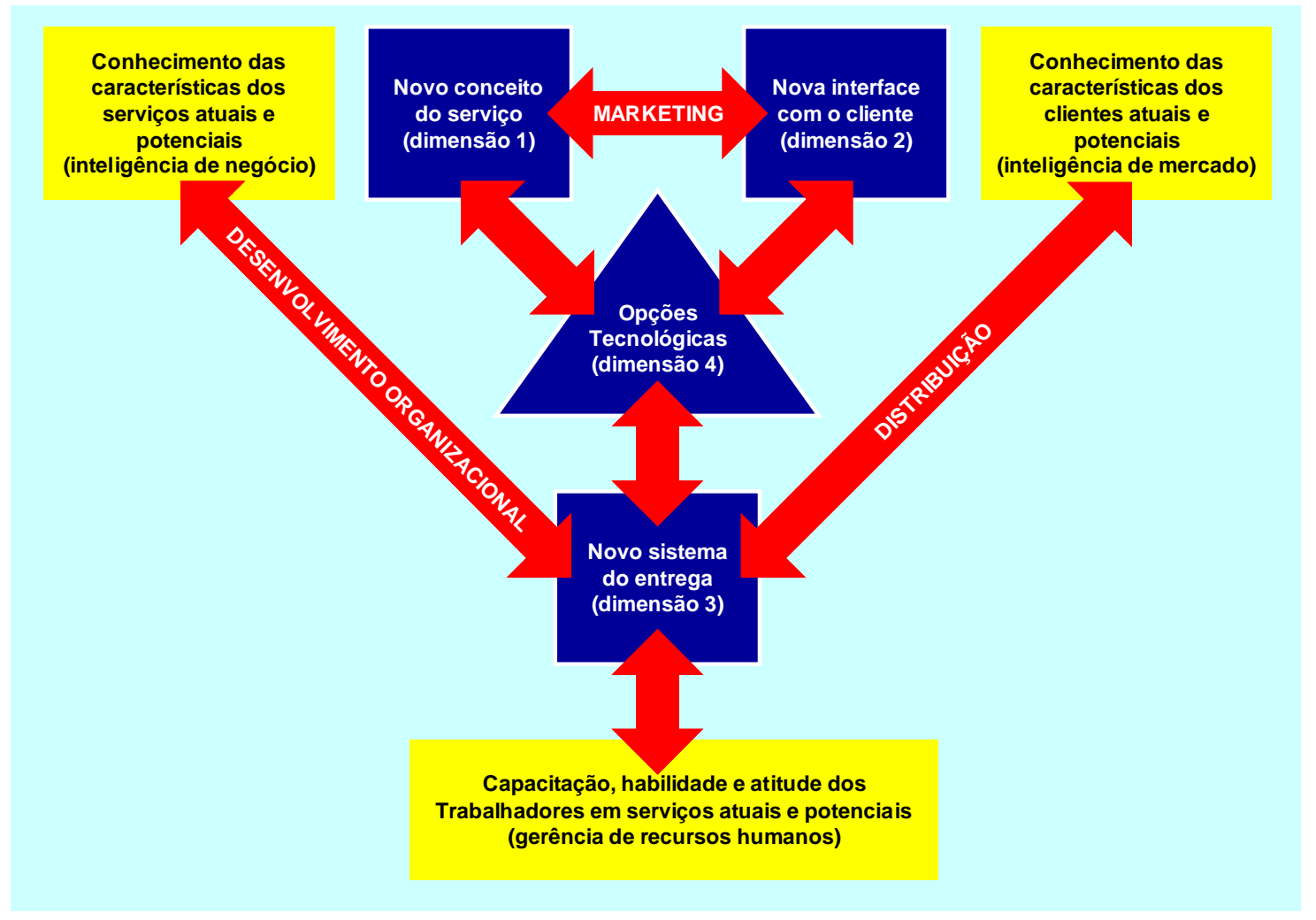

Figura 2 - Um modelo de quatro dimensões da inovação em serviços

Fonte: Bilderbeek et al. (1998 apud KUBOTA, 2007, p. 217).

- Novo sistema de entrega: a terceira dimensão diz respeito aos sistemas e à organização da entrega dos serviços, e se refere aos arranjos organizacionais internos que devem ser gerenciados para permitir que os funcionários executem de modo adequado suas tarefas, e oferecer serviços inovadores.

- Opções tecnológicas: a quarta dimensão é o centro de muita análise e debate, mas, para os autores, as inovações em serviços podem ocorrer sem necessariamente serem tecnológicas. Entretanto, mesmo em serviços, na maioria das inovações, a tecnologia está envolvida, especialmente a TIC.

Kubota (2006), conclui que uma inovação pode afetar mais fortemente uma determinada dimensão do que as demais, o que pode gerar uma série de mudanças nas outras. As relações entre as dimensões, que ocorrem através das atividades de marketing, distribuição e organização, são de importância crucial para a realização das inovações. 
2.2.3. Modelo do ciclo reverso do produto

De acordo com Kubota (2006), o modelo do ciclo reverso do produto ou Reverse Product Cycle (RPC) foi introduzido por Barras, em 1986 como um modelo teórico sobre a inovação no setor de serviços baseados em Tecnologia da Informação (TI).

Segundo Gallouj (2007), o modelo RPC nasce da constatação do Barras: as diferentes ondas de informatização que se originam em ciclo de vida da inovação nos serviços articula, sucessivamente, uma fase de inovação do processo incremental, uma fase de inovação de processo radical e uma fase de inovação de produto. Barras observa que esse ciclo de inovação é inverso ao ciclo tradicional na indústria manufatureira ${ }^{2}$ (daí a denominação do "ciclo reverso") e que a inovação não reside nesses sistemas ${ }^{3}$, mas nas mudanças que eles possibilitam por meio de toda gama do espectro dos processos de aprendizado: aprendizado pela prática, o uso, a interação, a consultoria, etc.

A seguir, as três fases do modelo RPC serão descritas com base no Gallouj (2007), Kubota (2006) e Vargas (2002): i) as inovações de processos incrementais dominantes no decorrer da primeira fase do ciclo são inovações de back office, onde as aplicações de novas tecnologias são desenhadas para aumentar a eficiência dos serviços existentes para reduzir significativamente os custos. Trata-se, por exemplo, da inscrição informatizada das apólices de seguro, da informatização dos registros de pessoal e dos salários; ii) as inovações radicais da segunda fase do ciclo referem-se essencialmente ao front office, onde a tecnologia é aplicada para melhorar a qualidade do serviço, visando a expansão dos mercados. A tecnologia é direcionada para um processo inovativo mais abrangente, buscando mais eficácia do que a eficiência na entrega de serviços e mais incremento na qualidade do que a redução dos custos. Trata-se, por exemplo, da gestão informatizada da lista de espera de atribuição de moradia nas administrações municipais, das prestações de

\footnotetext{
${ }^{2}$ Segundo Kubota (2006), esse ciclo é conhecido como ciclo normal do produto que trata a inovação aplicada ao setor de produção de bens de capital que adotam novas tecnologias como a TI. É constituído de três fases: de introdução, de crescimento e maturidade. Pode-se dizer, ainda, que existe uma quarta fase, de transição, em que o ciclo recomeça.

${ }^{3}$ Segundo Gallouj (2007), essa constatação do Barras constitui um avanço importante em relação à maioria dos trabalhos anteriores "em termos de impacto" (isto é, grau de novidade das inovações) no estudo de inovações em serviços.
} 
contas informatizadas nas empresas de contabilidade e da instalação de guichês automáticos em bancos; iii) nesta fase, as inovações de produto passam a prevalecer sobre as de processos e a ênfase competitiva recai sobre a diferenciação de produtos para capturar novos mercados, e existe a tendência do crescimento de emprego. Trata-se, por exemplo, de banco em domicílio (home bank), do voto eletrônico e da entrega de imposto de renda via internet.

Porém, para Gallouj (2007), o modelo RPC apresenta certo número de limites, dentre os quais destaca os seguintes: i) o modelo RPC não se constitui efetivamente em uma teoria de inovação, e sim uma teoria da difusão da inovação tecnológica de origem industrial nos serviços; ii) ele não leva em conta as formas não tecnológicas da inovação e, assim, no caso de banco, o modelo RPC classifica os guichês e os caixas automáticos eletrônicos como inovação de processo radical, o do banco em domicílio como inovação de produto, mas em nenhum caso, trata-se de atividade bancária e financeira, como sinônimo da inovação neste setor; iii) mesmo para esse objeto de análise restrito que constitui a tecnologia, o campo de validade do modelo não parece ultrapassar a fronteira dos serviços pré-industriais de massa (banco, seguro, administração).

Enfim, existem outras tecnologias além da que as ferramentas de informática (por exemplo, as tecnologias de transporte e, mais globalmente, as de tratamento de matéria etc.) que têm papel importante nos serviços, mas que estão excluídas do modelo.

Outras críticas fortes ao modelo RPC partiram de Uchupalanan (2000 apud KUBOTA, 2006, p. 40), apontando as seguintes deficiências: i) o modelo considera uma única fonte de inovação, a Tl; ii) o modelo apresenta dicotomia entre produto e processo; iii) o modelo não define precisamente o que é um novo serviço; iv) o modelo considera que as empresas de serviços são recipientes passivos da inovação dos fornecedores da TI; v) o modelo ignora o escopo de melhoria simultânea de eficiência, qualidade e introdução de novos serviços. 
2.2.4. Modelo único de representação das diversas formas de inovação - uma abordagem integradora de inovação

Em busca de uma abordagem integrada de bens e serviço, conforme já citado anteriormente, Gallouj (2007), propôs um modelo único de representação das diversas formas de inovação, representado por um conjunto de vetores de características ou de competências colocados em correspondência.

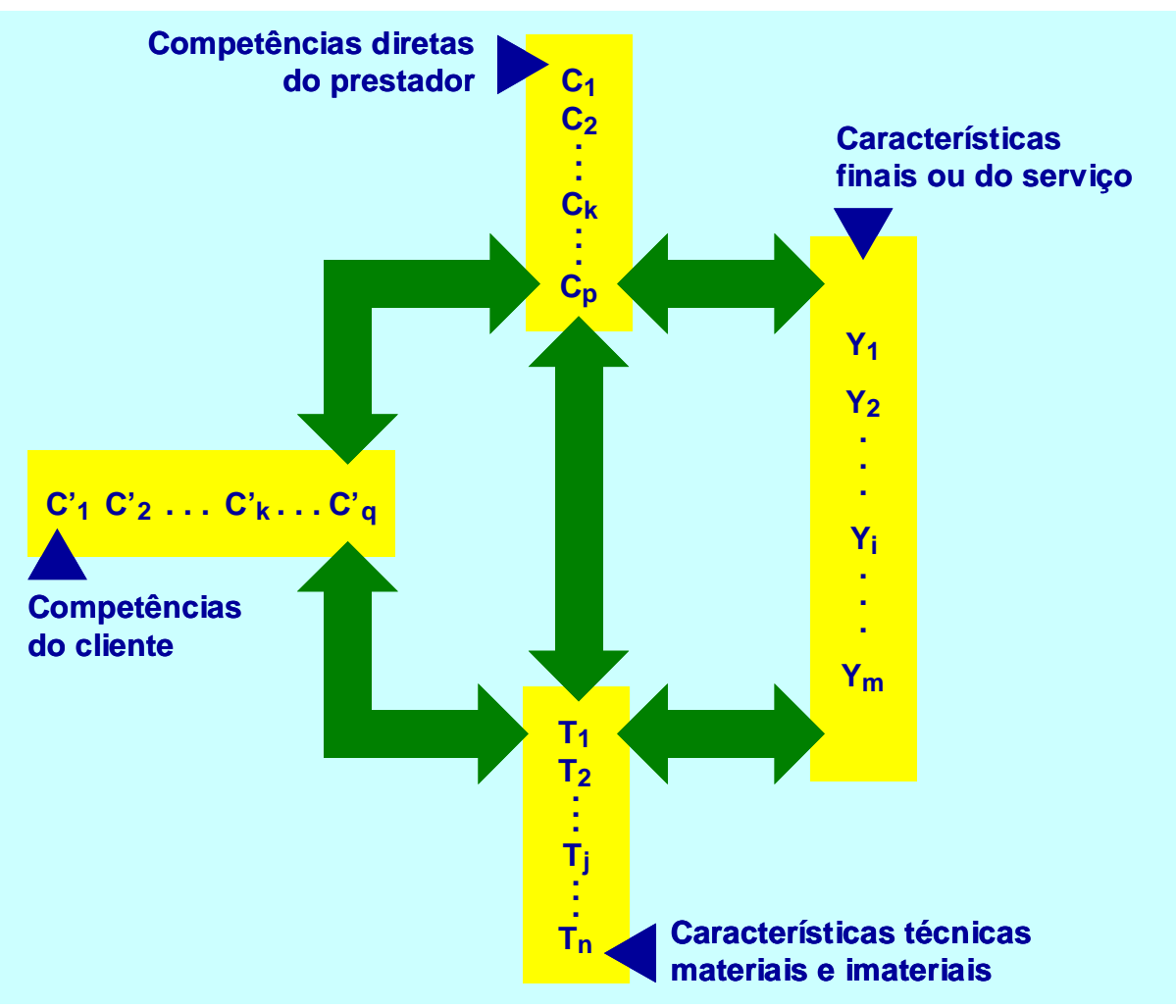

Figura 3 - 0 produto como vetores de características e de competências colocadas em correspondência

Fonte: Gallouj e Weinstein (1997 apud Gallouj, 2007, p. 14).

Estes vetores, ilustrados na Figura 3, possuem a seguinte representação: i) [Y] representa as características de serviços, os valores de uso, as utilidades fornecidas ao cliente; ii) [T] corresponde às características técnicas materiais ou imateriais e do processo, isto é, os técnicos (métodos, sistemas técnicos de back office ou de front office) mobilizados para produzir as características de serviços; iii) [C] e [C'] referem-se às competências respectivas do prestador e do cliente cuja articulação [C] [C'] simboliza o que é denominado de interface da prestação. 
Dessa forma, uma prestação de serviços pode ser definida como a mobilização simultânea de características técnicas (materiais e imateriais) e de competências (internas e externas) para produzir características de serviços. Essa representação mostra certo número de casos particulares: i) o serviço puro, por exemplo, que é a mobilização direta de competências para produzir características de serviço [C]-[Y]; ii) a relação [C']-[Y] que traduz a configuração habitual de um bem material; o sistema [C']-[T]-[Y] que descreve uma relação de auto-serviço.

Partindo da definição da inovação como toda mudança que afeta um ou vários termos do vetor de características (técnicas, de serviços) ou de competências, essas mudanças cobrem diferentes mecanismos elementares: evolução ou variação, desaparecimento, aparecimento, associação, dissociação, formatação (no sentido etimológico, isso é dar uma forma a um elemento "vago"). Eles podem ser programados, isto é, intencionais, oriundos de uma atividade voluntária de P\&D, de concepção, de inovações, ou "emergentes" - ou seja, o fruto de mecanismos naturais de aprendizado.De acordo com Gallouj (2007), a inovação não é um resultado, mas um processo e, assim, mais do que "formas" de inovação, interessa-se pelo "modo" ou "modelo" de inovação que descrevem as dinâmicas específicas de características. Dessa forma, o autor apresenta vários modelos de inovação corroborados em vários trabalhos empíricos realizados, conforme relacionados a seguir:

- Inovação radical: em uma concepção ampla, esse modelo de inovação descreve a criação de um conjunto de características $\left\{\left[\mathrm{C}^{*}\right],\left[\mathrm{C}^{\star}\right],\left[\mathrm{T}^{\star}\right],\left[\mathrm{Y}^{\star}\right]\right\}$ e , em uma concepção estreita, a criação de um novo conjunto características $\left\{\left[\mathrm{C}^{*}\right],\left[\mathrm{C}^{\star}\right],\left[\mathrm{T}^{\star}\right]\right\}$, mesmo se $\left[\mathrm{Y}^{\star}\right]$ permaneça inalterado. De fato, passagem da carroça, puxada por cavalos, ao veiculo a motor ou, ainda, o aparecimento do carro elétrico são inovações radicais, mesmo se, de certo modo, as características de serviço forem as mesmas: trata-se de transportar indivíduos em certas condição de conforto, de segurança e de velocidade;

- Inovação pela melhoria: ele traduz o aumento da qualidade de determinadas características sem modificações da estrutura do sistema $\left\{\left[C^{\prime}\right]\right.$, $[\mathrm{C}],[\mathrm{T}],[\mathrm{Y}]\}$. Essa elevação da qualidade das características de serviço pode ser obtida diretamente, melhorando certas competências, C, ou determinadas características técnicas, T. A inovação da melhoria é um modo de inovação pela acumulação de competências, que se apóiam, principalmente, no efeito de aprendizado que normalmente acompanham qualquer atividade. 
- Inovação incremental: refere-se especificamente à adição de incrementos. A inovação incremental descreve a adjunção e, também, eventualmente, a suspensão e a substituição de características. Ela mantém a estrutura geral do sistema $\left\{\left[\mathrm{C}^{\prime}\right],[\mathrm{C}],[\mathrm{T}],[\mathrm{Y}]\right\}$, que é modificado apenas marginalmente;

- Inovação ad hoc: essa inovação é freqüente nas atividades intensivas em conhecimentos. As características de serviço [Y] de uma inovação ad hoc podem, então, ser encaradas como uma solução ou um conjunto de soluções originais de ordem organizacional, estratégica, jurídica, fiscal, social, humana, técnica etc., em resposta a um problema, em parte, inédito. Do ponto de vista do prestador, a inovação ad hoc, contribui com a produção de novos conhecimentos e de novas competências, precisando ser inscritas, codificadas e formalizadas de modo a torná-las reutilizáveis em outras circunstâncias: há, então, modificação sensível do vetor das competências [C], mas principalmente do vetor de características técnicas [T] nos seus componentes imateriais.

- Inovação pela recombinação: essa modalidade de inovação baseia-se nos princípios elementares de dissociação e de associação das características finais e técnicas. A inovação incremental pode ser considerada uma forma particular de inovação de recombinação, principalmente quando as características adicionais provêm de produtos preexistentes. Mas duas outras modalidades são possíveis e podem ser particularmente evidenciadas no campo dos serviços: a primeira consiste em criar um novo produto associando as características de dois ou mais produtos, e a segunda, ao contrário, em criar novos produtos fracionando um produto, dissociando diferentes características e fazendo de certos componentes produtos autônomos;

- Inovação pela formalização ou pela objetivação: essa modalidade de inovação traduz a formatação e a padronização das características. Ela designa um conjunto heterogêneo de mecanismos que permitem esboçar a silhueta dessa entidade vaga que constitui o serviço, isto é, que permite atribuir-lhe certo grau de materialidade. Essa materialidade pode ser atingida por dois tipos de mecanismos diferentes que podem ser conjugados: i) mecanismos tangíveis: é o caso, por exemplo, da introdução de sistemas técnicos na fórmula de serviço (trata-se de que, em geral, é chamado de 
inovações de processos; ii) mecanismos intangíveis: a introdução de métodos, isto é, de roteiros que descrevem a distribuição das funções nessa verdadeira "representação" que é a prestação de serviços; a concepção e o uso de caixas de ferramentas comportando instrumentos analíticos que estruturam os pensamentos e os comportamentos (por exemplo, as matrizes $\left.B C G^{4}\right)$; a implantação de uma organização que incorpore o serviço imaterial.

\subsection{Inovação em serviços no Setor Público Brasileiro}

Segundo Farah (2000), a partir da revolução de 30, estabelecem-se bases do nacional-desenvolvimentismo no Brasil. Inicia-se, então, ciclo centralizador do federalismo brasileiro, acompanhado de uma nova definição do papel do Estado: o do indutor do desenvolvimento nacional e de articulador da construção de uma identidade nacional. As décadas que se seguem caracterizam-se por processos de inovação institucional e de introdução de novas práticas na administração pública brasileira. A autora ressalta que o período autoritário foi marcado por inovações institucionais e nas práticas governamentais, portanto a introdução de inovações no setor público não se dá apenas em contexto competitivo, como ocorre no setor privado.

A partir da década de 1970, inicia-se estabelecimento de um novo conjunto de novos valores, impulsionados pelas mudanças no país e no mundo. Estes valores são denominados, por Motta (1999), de valores da pós-modernidade gerencial, os quais provocam mudanças significativas nas organizações públicas do país. Assim, a pós-modernidade reconhece a emergência de uma nova sociedade, pós-industrial, baseada na informação, tecnologia, fragmentação, flexibilidade e livre-comunicação, assim como pela ausência de valores prévios definidos.

De acordo com Klering e Andrade (2006), impulsionadas por esta nova onda da pós-modernidade, emergem novas "organizações do futuro" com novos valores

\footnotetext{
4 Matriz BCG (Boston Consulting Group) é um modelo para análise de portfólio de produtos ou de unidades de negócio baseado no conceito de ciclo de vida do produto. Para garantir a criação de valor, a longo prazo, a empresa deve ter um portfólio de produtos que contenha tanto mercadorias com altas taxas de crescimento no mercado (que precisam de investimentos) e mercadorias com baixo crescimento (que geram receita). A matriz tem duas dimensões: crescimento do mercado e participação relativa de mercado (que é a participação da empresa em relação à participação de seu
} 
gerenciais. Motta (1999) sintetiza essas tendências em quatro grandes referências: i) empregabilidade e individualização do trabalho, em que a sociedade precisa garantir melhor acesso de pessoas ao trabalho, em meio a uma tendência de crescente automação, robotização e informatização; ii) descentralização do trabalho e responsabilidade social sobre o tempo livre, uma vez que o trabalho poderá ser realizado sem definição prévia do tempo e espaço; iii) auto-sustentabilidade e consciência ecológica; apelos à transcendência, espiritualidade e reconstrução da solidariedade. Estes novos valores passam a influenciar, definitivamente, as idéias e as práticas de inovação no setor público e privado, gerando novas perspectivas de atuação.

Neste contexto, para Klering e Andrade (2006), "inovar no setor público é efetivamente desenvolver uma nova condição em seus pressupostos nas suas ações", dentro, agora, dessa nova perspectiva da pós-modernidade. Nesta perspectiva, para ser considerada uma inovação, não basta apenas mudar ou propor novas reformas, sem trazer transformação significativa no processo de definição e implementação de políticas públicas. Assim, é necessário tratar a inovação no seu sentido mais amplo, no qual os novos-aspectos, os processos e os atores são considerados, produzindo novos sentidos e significados, assim como maiores e mais amplos impactos sociais. Considerando este cenário, Motta (1999) propõe adoção do conceito abrangente para a inovação, considerando e incorporando, tanto quanto possível, as mudanças de caráter estratégico, estrutural, tecnológico, humano, cultural, político e de controle, visando produzir impactos e desenvolvimentos sociais mais amplos.

Segundo Farah (2000), o debate sobre reformas no setor público tem trazido proposições diferenciadas, mesmo que partindo dos mesmos pressupostos de eficiência do setor, por exemplo, uma Nova Administração Pública, também conhecido como gerencialismo, tem como princípio básico a adoção de padrões gerenciais, utilizados pelo setor privado, voltado à eficiência e qualidade dos serviços, importando os princípios adotados pelo mercado competitivo. Assim, a adoção cega de padrões do setor privado, sem considerar as especificidades do contexto público, pode trazer efeitos perversos. Dessa forma, segundo Klering e Andrade (2006), para implementação de inovação em serviço no setor público 
ressalta-se a necessidade de uma reflexão profunda sobre a transformação do setor público a partir de seu próprio contexto, considerando a relação entre cidadão e governos na condução das ações do setor público e, também, na qualidade e na eficiência de serviços públicos, dentro de uma preocupação comum com a efetividade da estrutura pública.

$\mathrm{Na}$ análise de Klering e Andrade (2006), as práticas inovadoras se caracterizam como novas formas de definir o conteúdo de públicas e de gerenciálas, principalmente, através da participação de novos atores, da implementação de novas políticas e constituição de novos arranjos. Assim, Andrade (2001) propõe uma modelo para análise do processo de inovação em serviços no setor público, baseado em quatro dimensões, conforme ilustra o Quadro 1.

\begin{tabular}{|l|l|}
\hline \multicolumn{1}{|c|}{ Dimensão da Inovação } & \multicolumn{1}{c|}{ Processo de inovação no setor público } \\
\hline $\begin{array}{l}\text { Dimensão 1: Ligação entre demanda } \\
\text { externa e a eficiência interna }\end{array}$ & $\begin{array}{l}\text { Mudança no conteúdo e na natureza dos serviços } \\
\text { direcionados à cidadania }\end{array}$ \\
\hline $\begin{array}{l}\text { Dimensão 2: Lidar com a complexidade } \\
\text { e transpor rotinas }\end{array}$ & $\begin{array}{l}\text { Integração de novos atores e espaços na mobilização de } \\
\text { recursos e a proposição de ações interorganizacionais }\end{array}$ \\
\hline $\begin{array}{l}\text { Dimensão 3: Balancear controle e } \\
\text { criatividade }\end{array}$ & $\begin{array}{l}\text { Novas formas de planejamento e participação de novos } \\
\text { atores }\end{array}$ \\
\hline $\begin{array}{l}\text { Dimensão 4: Balancear resultados e } \\
\text { legitimar a inovação }\end{array}$ & Foco na inclusão social e no exercício da cidadania \\
\hline
\end{tabular}

Quadro 1 - Dimensões do processo de inovação no setor público

Fonte: Adaptado de Klering e Andrade (2006, p. 91).

De acordo com Andrade (2001), as quatro dimensões podem ser compreendidas da seguinte forma: i) a primeira dimensão trata da tensão entre demanda externa e a eficiência interna, relativa à transformação no conteúdo dos serviços e com a ampliação dos serviços; ii) a segunda dimensão trata das tensões entre lidar com a complexidade e transpor rotinas relacionadas à inclusão de novos atores e adoção de ações interorganizacionais; iii) a terceira dimensão trata da tensão entre o controle e a abertura para criatividade relacionada a quebra de formas de planejamento tradicional no setor público, que tem os governos como ator central para a inclusão de novos atores no processo de planejamento e implementações de ações; iv) a quarta dimensão trata a tensão em gerar resultados e legitimar a inovação relacionadas às ações voltadas a inclusão e participação social. Para o autor, essas dimensões ajudam a compreender o significado das inovações que estão nas organizações.

A seguir, são relacionadas diversas práticas inovadoras de gestão pública, traduzidas em uma relação de características e qualidades, doravante denominados 
de atributos, mapeadas pela literatura revisada por Klering e Andrade (2006), conforme ilustrado no Quadro 2.

\begin{tabular}{|c|c|}
\hline $\begin{array}{l}\text { Características e } \\
\text { Atributos }\end{array}$ & Descrição \\
\hline $\begin{array}{l}\text { Introdução de mudanças, } \\
\text { qualitativas e } \\
\text { quantitativas, em relação } \\
\text { às práticas anteriores }\end{array}$ & $\begin{array}{l}\text { Um projeto deve introduzir novos modos ou modelos de provisão de } \\
\text { bens e serviços, ser capaz de mudar hábitos ou costumes de trabalho, } \\
\text { desenvolver produtos e serviços, tanto novos, quanto renovar os } \\
\text { antigos. }\end{array}$ \\
\hline $\begin{array}{l}\text { Melhoria da qualidade de } \\
\text { vida do público-alvo }\end{array}$ & $\begin{array}{l}\text { Um projeto deve ser capaz de gerar fontes de renda, ou melhorar a } \\
\text { habitação, saneamento, saúde, educação do público-alvo; aumentar } \\
\text { os cuidados com o meio ambiente, as relações com as comunidades, } \\
\text { a segurança, a liberdade de expressão, a auto-estima dos cidadãos. }\end{array}$ \\
\hline Auto-sustentabilidade & $\begin{array}{l}\text { Um projeto deve ser capaz de vir a sustentar-se de forma própria e } \\
\text { autônoma, tendo em vista seu enfoque no desenvolvimento das } \\
\text { pessoas e instituições envolvidas, evitando práticas paternalistas. }\end{array}$ \\
\hline $\begin{array}{l}\text { Viabilidade técnica, } \\
\text { gerencial, econômica e } \\
\text { financeira }\end{array}$ & $\begin{array}{l}\text { Um projeto deve ser exeqüível em termos técnicos, gerenciais, } \\
\text { econômicos e financeiros, ou seja, dispor de tecnologia e recursos } \\
\text { suficientes e adequados para a sua implementação, e proporcionar } \\
\text { adequada relação custo-benefício. }\end{array}$ \\
\hline Credibilidade pública & $\begin{array}{l}\text { Um projeto deve merecer, das instituições envolvidas na sua } \\
\text { implantação, uma efetiva importância e visibilidade interna, e oferecer } \\
\text { pronta resposta a demandas do público-alvo. }\end{array}$ \\
\hline Accountability & $\begin{array}{l}\text { Um projeto deve ter suas contas e seu funcionamento apresentados } \\
\text { de forma clara, objetiva e transparente aos seus apoiadores e à } \\
\text { sociedade em geral, com prestações regulares de contas. }\end{array}$ \\
\hline $\begin{array}{l}\text { Desenvolvimento de } \\
\text { tecnologia e } \\
\text { responsabilidade na } \\
\text { utilização de recursos e } \\
\text { oportunidades }\end{array}$ & $\begin{array}{l}\text { Um projeto deve melhorar a gestão de recursos sociais, criando novas } \\
\text { tecnologias, desenvolvendo novas habilidades de ação, dentro de } \\
\text { critérios de ética, correção e justiça. }\end{array}$ \\
\hline $\begin{array}{l}\text { Consolidação e ampliação } \\
\text { do diálogo com a } \\
\text { sociedade civil }\end{array}$ & $\begin{array}{l}\text { Um projeto deve melhorar a comunicação, interação e envolvimento de } \\
\text { uma comunidade, em relação a assuntos de seu interesse, criando } \\
\text { uma maior "massa crítica" e consciência social, assim como maior } \\
\text { responsabilidade pelas coisas públicas. }\end{array}$ \\
\hline $\begin{array}{l}\text { Articulação com } \\
\text { diferentes setores sociais }\end{array}$ & $\begin{array}{l}\text { Um projeto deve melhorar a comunicação, interação e envolvimento } \\
\text { entre os diferentes setores e atores sociais: o setor público, o setor } \\
\text { privado e o chamado "terceiro setor", em relação a demandas e } \\
\text { assuntos de interesse real e potencial da sociedade, criando maior } \\
\text { responsabilidade e solidariedade social, formulando e implementando } \\
\text { soluções, principalmente via rede de ações }\end{array}$ \\
\hline $\begin{array}{l}\text { Articulação com } \\
\text { diferentes atores, grupos, } \\
\text { coletivos e segmentos } \\
\text { sociais }\end{array}$ & $\begin{array}{l}\text { Um projeto deve melhorar a comunicação, participação e } \\
\text { comprometimento de diferentes atores, grupos de interesse real e } \\
\text { potencial da sociedade, criando maior responsabilidade social, } \\
\text { engajamento cívico e solidariedade social, via atuação preferencial em } \\
\text { redes. }\end{array}$ \\
\hline $\begin{array}{l}\text { Articulação entre } \\
\text { governos de um mesmo } \\
\text { nível }\end{array}$ & $\begin{array}{l}\text { Um projeto deve melhorar o entendimento e a busca de soluções } \\
\text { conjuntas entre governo de mesmo nível, pela formação de parcerias, } \\
\text { associações em redes de atuação conjunta, de grupos de município ou } \\
\text { grupos de estado. }\end{array}$ \\
\hline $\begin{array}{l}\text { Articulação entre } \\
\text { governos de diferentes } \\
\text { níveis }\end{array}$ & $\begin{array}{l}\text { Um projeto deve melhorar o entendimento e a busca de soluções } \\
\text { conjuntas entre governo de diferentes níveis, pela formação de } \\
\text { parcerias para atuação conjunta, em que cada ente federativo cumpre } \\
\text { determinado papel, como parte de um sistema ou de uma rede, } \\
\text { visando alcançar objetivos comuns entre municípios e estados e a } \\
\text { União. }\end{array}$ \\
\hline Transferibilidade & $\begin{array}{l}\text { Um projeto deve criar condições e tecnologias transferíveis e } \\
\text { aproveitáveis em outras áreas, contextos, administrações e regiões. }\end{array}$ \\
\hline Ampliação do número de & Um projeto deve gerar impactos sobre, não apenas para o público-alvo \\
\hline
\end{tabular}




\begin{tabular}{|c|c|}
\hline $\begin{array}{c}\text { Características e } \\
\text { Atributos }\end{array}$ & Descrição \\
\hline beneficiários & $\begin{array}{l}\text { principal, mas também, sobre outros cidadãos e segmentos } \\
\text { localizados ao redor, passíveis de serem sensibilizados e beneficiados } \\
\text { de forma indireta. }\end{array}$ \\
\hline $\begin{array}{l}\text { Permeabilidade ao } \\
\text { público-alvo }\end{array}$ & $\begin{array}{l}\text { Um projeto deve aproximar-se do público-alvo, ser compreensível, } \\
\text { suficientemente simples, informal e coerente com o modo de vida } \\
\text { prevalente, para ser facilmente contatado, assimilado e adotado na } \\
\text { vida cotidiana dos cidadãos. }\end{array}$ \\
\hline $\begin{array}{l}\text { Simplificação da vida dos } \\
\text { cidadãos }\end{array}$ & $\begin{array}{l}\text { Um projeto deve facilitar e simplificar o acesso dos cidadãos a bens e } \\
\text { serviços públicos e sociais; deve racionalizar ações, visando maior } \\
\text { eficácia, sem desconsiderar aspectos de tradições, de afeições e de } \\
\text { valores do público-alvo. }\end{array}$ \\
\hline $\begin{array}{l}\text { Inclusão de minorias } \\
\text { sociais }\end{array}$ & $\begin{array}{l}\text { Um projeto deve estimular a inclusão ou reinclusão de minorias } \\
\text { desfavorecidas historicamente na sociedade, privilegiando maior } \\
\text { integração e participação social de segmentos étnicos, de gênero, de } \\
\text { idade e de classes sociais que foram historicamente desfavorecidos e } \\
\text { prejudicados. }\end{array}$ \\
\hline $\begin{array}{l}\text { Incorporação de } \\
\text { tecnologias facilitadoras } \\
\text { da ação pública }\end{array}$ & $\begin{array}{l}\text { Um projeto deve estimular a introdução de novas tecnologias (como } \\
\text { internet, sistemas de acompanhamento informatizado e outros) que } \\
\text { facilitem e tornem mais eficaz a ação pública, rompendo ou quebrando } \\
\text { paradigmas de ação mais antigos e menos eficazes. }\end{array}$ \\
\hline $\begin{array}{l}\text { Fortalecimento do poder } \\
\text { de gerenciamento para } \\
\text { governos }\end{array}$ & $\begin{array}{l}\text { Um projeto deve fortalecer e até devolver capacidade de } \\
\text { gerenciamento efetivo ao setor público; ao mesmo tempo que delega } \\
\text { ações, deve fortalecer a capacidade de planejar, definir estratégias } \\
\text { amplas e gerais, visando articular melhor as ações de diferentes atores } \\
\text { e setores da sociedade. }\end{array}$ \\
\hline Enfoque sistêmico & $\begin{array}{l}\text { Um projeto deve ter enfoque sistêmico, em que as partes } \\
\text { desempenham um papel integrativo para alcance de objetivos comuns; } \\
\text { se aceita caminhos ou opções alternativas (em vez de lineares e } \\
\text { únicas); considerando-se o sistema focado como contendo partes, e } \\
\text { ao mesmo tempo, fazendo parte de um sistema maior; se aceita } \\
\text { constantes prevenções, reavaliações e reajustes; se enfatiza mais } \\
\text { perspectivas dinâmicas e integrativas, do que estatísticas pontuais. }\end{array}$ \\
\hline
\end{tabular}

Quadro 2 - Lista de atributos presentes num projeto inovador no setor público

Fonte: Klering e Andrade (2006, p. 92-95).

Segundo Klering e Andrade (2006), o Quadro 2 apresenta uma lista bastante coerente e completa de atributos de práticas inovadoras, do setor público, que facilita a identificação e reconhecimento de aspectos inovadoras importantes, de projetos que tenham a intenção de transformar para melhor, realidades e sociedades, com base em gestão pública eficaz, voltada para a ampliação do espaço e do conceito de cidadania.

De acordo com Farah (2006), o processo de inovação no setor público encontra-se, ainda, em estágio "em construção", com o alcance das iniciativas inovadoras relativamente limitadas e grau de maturidade das organizações públicas em estágios diferenciadas, no que tange às práticas inovadoras. No entanto, para a autora, existe um potencial de disseminação e consolidação dessas iniciativas, cujo desdobramento depende dos atores envolvidos nas transformações em curso.

Ainda, Farah (2006) chama atenção para o ciclo de inovações como 
grandes desafios e oportunidades, pois à medida que há superação do "velho" pelo "novo", à medida que novas políticas são institucionalizadas nas instituições e práticas se tornam efetivas, novos problemas (não antecipados) tendem a surgir, colocando-os como desafios às novas inovações. Dessa forma, a inovação constitui um processo permanente, entendida como busca de resposta a novos desafios.

No âmbito desta monografia, a lista de atributos pode ser aplicada como base para medição de inovações dos projetos de serviços desenvolvidas pela SUNAF, uma unidade de uma empresa pública, sendo um dos instrumentos de implementação de políticas públicas brasileiras, através de implementação e disponibilização de serviços de TIC. 


\section{METODOLOGIA}

De acordo com Gil (1996), uma pesquisa é desenvolvida com base nos conhecimentos disponíveis e a aplicação cuidadosa dos métodos e técnicas e outros procedimentos científicos, envolvendo um planejamento consistente que define as diversas fases, desde a formulação do problema até a efetiva apresentação dos resultados da pesquisa.

Neste capítulo são descritas as estratégias metodológicas adotadas para a realização desta pesquisa, observando o conceito apresentado e as razões da escolha realizada.

\subsection{Tipo de pesquisa}

Trata-se de um Estudo de Caso que visa caracterizar o processo de inovações em serviços de TIC implementado pela SUNAF, baseado em uma pesquisa qualitativa de natureza descritiva tendo como fontes de evidências as documentações, os registros em arquivos, as entrevistas e a observação do participante.

Segundo Yin (2005), as pesquisas podem ser classificadas quanto à estratégia em: experimentos, levantamentos, pesquisas históricas, análise de informações em arquivos e estudos de caso. Cada estratégia apresenta um conjunto de vantagens e desvantagens próprias condicionadas, basicamente, aos seguintes fatores: i) Tipo de questão da pesquisa; ii) o controle que o pesquisador possui sobre os eventos comportamentais; iii) o foco em fenômenos históricos, em oposição a fenômenos contemporâneos.

De acordo como Yin (2005), em geral, os estudos de caso representam a estratégia preferida quando se colocam questões do tipo "como e por que", isto é, na busca de maiores conhecimentos para contribuir para análise e compreensão dos fenômenos individuais, organizacionais, sociais, políticos e de grupos, além de outros fenômenos relacionados. Desta forma, segundo o autor, 
...o estudo de caso permite uma investigação para se preservar as características holísticas e significativas dos acontecimentos da vida real tais como ciclos de vidas individuais, processos organizacionais e administrativos, mudanças ocorridas em regiões urbanas, relações internacionais e a maturação dos setores econômicos (YIN, 2005, p.20).

Quanto à forma de abordagem, a pesquisa pode ser classificada em qualitativa e quantitativa, conforme Yin (2005), Creswell (2007) e Godoy (1995). Ainda segundo os autores, embora nas duas abordagens, os processos de pesquisas sejam similares, pois consistem em um esforço cuidadoso para a descoberta de novas informações ou relações para verificação e ampliação do conhecimento existente, eles são orientados por caminhos diferenciados. Segundo Creswell (2007), a investigação qualitativa aplica diferentes alegações de conhecimento, estratégias de investigação e métodos de coleta e análise de dados. No Quadro 3, estão relacionadas e descritas as principais características do procedimento da pesquisa qualitativa, a saber:

\begin{tabular}{|c|c|}
\hline Cara & Descrição \\
\hline $\begin{array}{l}\text { Ocorre } n \\
\text { natural. }\end{array}$ & $\begin{array}{l}\text { a condução da pesquisa, o pesquisador qualitativo sempre vai ao local } \\
\text { de se encontram participantes. Isto permite maior envolvimento nas } \\
\text { periências reais dos participantes ou do contexto de pesquisa. }\end{array}$ \\
\hline $\begin{array}{l}\text { Utiliza diversos } \\
\text { métodos interativos e } \\
\text { humanos. }\end{array}$ & $\begin{array}{l}\text { Os pesquisadores qualitativos buscam envolvimento dos participantes } \\
\text { da coleta de dados e procuram estabelecer harmonia e credibilidade } \\
\text { com as pessoas, direta e indiretamente, envolvidas na pesquisa. Eles } \\
\text { devem estar atentos para não "perturbarem" o ambiente. Podem } \\
\text { utilizar-se de métodos de coleta de dados, tais como observações } \\
\text { abertas, entrevistas e documentos; e um vasto leque de materiais como } \\
\text { sons, e-mails, álbum de recortes etc. Os dados coletados envolvem } \\
\text { dados em texto (ou palavras), dados em imagem (ou fotos) e sons. }\end{array}$ \\
\hline $\begin{array}{l}\text { É emergente em vez de } \\
\text { estritamente pré- } \\
\text { configurada. }\end{array}$ & $\begin{array}{l}\text { A medida que a pesquisa avança e aumenta o conhecimento do objeto } \\
\text { da pesquisa, as questões de pesquisa podem mudar e ser refinadas. O } \\
\text { processo de coleta de dados pode mudar à medida que as portas se } \\
\text { abrem ou se fecham para coleta de dados, e o pesquisador descobre } \\
\text { os melhores locais para entender o fenômeno central de interesse. }\end{array}$ \\
\hline $\begin{array}{l}\text { É funda } \\
\text { interpre }\end{array}$ & $\begin{array}{l}\text { O pesquisador faz interpretação dos dados, incluindo o } \\
\text { desenvolvimento da descrição de uma pessoa ou de um cenário, } \\
\text { análise de dados para identificação de temas ou categorias e, } \\
\text { finalmente, fazer uma interpretação ou tirar conclusões sobre } \\
\text { significado, pessoal e teoricamente, mencionando as lições oferecidas } \\
\text { e oferecendo mais perguntas a serem feitas. Isso significa que o } \\
\text { pesquisador filtra os dados através de uma lente pessoal situada em } \\
\text { um momento sócio-político e histórico específico. Não é possível evitar } \\
\text { as interpretações pessoais na análise de dados qualitativos. }\end{array}$ \\
\hline $\begin{array}{l}\text { Possui visões amplas } \\
\text { em vez de micro- } \\
\text { análises. }\end{array}$ & $\begin{array}{l}\text { O pesquisador qualitativo enxerga os fenômenos sociais de forma } \\
\text { holística. Quanto mais complexa, interativa e abrangente a narrativa, } \\
\text { melhor o estudo qualitativo. Os modelos gráficos multifacetados de um } \\
\text { processo ou de um fenômeno central ajudam a estabelecer esse } \\
\text { quadro holístico. }\end{array}$ \\
\hline Possui refletividade. & $\begin{array}{l}\text { O pesquisador qualitativo reflete sistematicamente sobre quem ele é na } \\
\text { investigação e é sensível à sua biografia pessoal e à maneira como ela } \\
\text { molda o estudo.Isso, também representa honestidade e abertura para } \\
\text { pesquisa, reconhecendo que toda investigação é carregada de valores. }\end{array}$ \\
\hline
\end{tabular}




\begin{tabular}{|l|l|}
\hline \multicolumn{1}{|c|}{ Características } & \multicolumn{1}{|c|}{ Descrição } \\
\hline $\begin{array}{l}\text { Exige um raciocínio } \\
\text { complexo } \\
\text { multifacetado, } \\
\text { interativo e simultâneo. }\end{array}$ & $\begin{array}{l}\text { O pesquisador qualitativo deve ter raciocínio um raciocínio complexo } \\
\text { multifacetado, interativo e simultâneo. Embora o raciocínio seja, em } \\
\text { grande parte, indutivo, tanto processos indutivos como os dedutivos } \\
\text { devem ser aplicados. O processo de pensamento também é interativo, } \\
\text { fazendo um ciclo que vai da coleta e análise de dados até a } \\
\text { reformulação do problema e voltando. Acrescenta-se a isso, as } \\
\text { atividades simultâneas de coleta, análise e comunicação dos dados. }\end{array}$ \\
\hline $\begin{array}{l}\text { Deve aplicar uma ou } \\
\text { mais estratégias de } \\
\text { investigação. }\end{array}$ & $\begin{array}{l}\text { O pesquisador qualitativo deve aplicar uma ou mais estratégia de } \\
\text { investigação como guia para os procedimentos no estudo. Para } \\
\text { pesquisadores iniciantes, é suficiente usar apenas uma estratégia e } \\
\text { buscar em livros recentes de procedimentos uma orientação sobre } \\
\text { como elaborar uma proposta e conduzir os procedimentos da } \\
\text { estratégia. }\end{array}$ \\
\hline
\end{tabular}

Quadro 3 - As principais características de uma pesquisa qualitativa.

Fonte: Creswell (2007, p.186 - 187).

As características gerais apresentadas, no Quadro 2, segundo Creswell (2007), apreendem tanto as perspectivas tradicionais como as mais recentes da investigação qualitativa reivindicatória, participativa e auto-reflexiva. Estas características serão utilizadas como orientação para definição do procedimento desta pesquisa.

Quanto à natureza, conforme citado anteriormente, será uma pesquisa descritiva, buscando caracterizar o processo de inovações em serviços, com base nos conceitos e nas teorias apresentadas no capítulo 2 .

\subsection{População e amostra}

De acordo com Bauer e Gaskell (2005, p. 39), "toda pesquisa social empírica seleciona evidências para argumentar e necessita justificar a seleção que é base de investigação, descrição, demonstração, prova ou refutação de uma afirmação específica". Dessa forma, a amostragem adequada garante a eficiência da pesquisa ao fornecer uma base lógica para o estudo de apenas parte de uma população sem que se perca as informações.

A seguir, serão apresentadas informações sobre a SUNAF que apoiaram a definição da amostra representativa. 


\subsubsection{Superintendência de Negócios Administração Financeira (SUNAF).}

A SUNAF é uma unidade de negócio, especializada em fornecer serviços de TIC no segmento de administração orçamentária e financeira para Governo Federal. Ela é uma das unidades que compõem a empresa pública Serviço Federal de Processamento de Dados (SERPRO, 2009a) ${ }^{5}$.

As principais macro-funções da superintendência são: gestão empresarial e comercial, gestão dos processos corporativos, gestão de serviços de TIC no segmento financeiro (prospecção de novos serviços, desenvolvimento e manutenção de serviços) e gestão da produção dos serviços. Para o exercício das macro-funções a SUNAF conta com uma estrutura organizacional ilustrada na Figura 4.

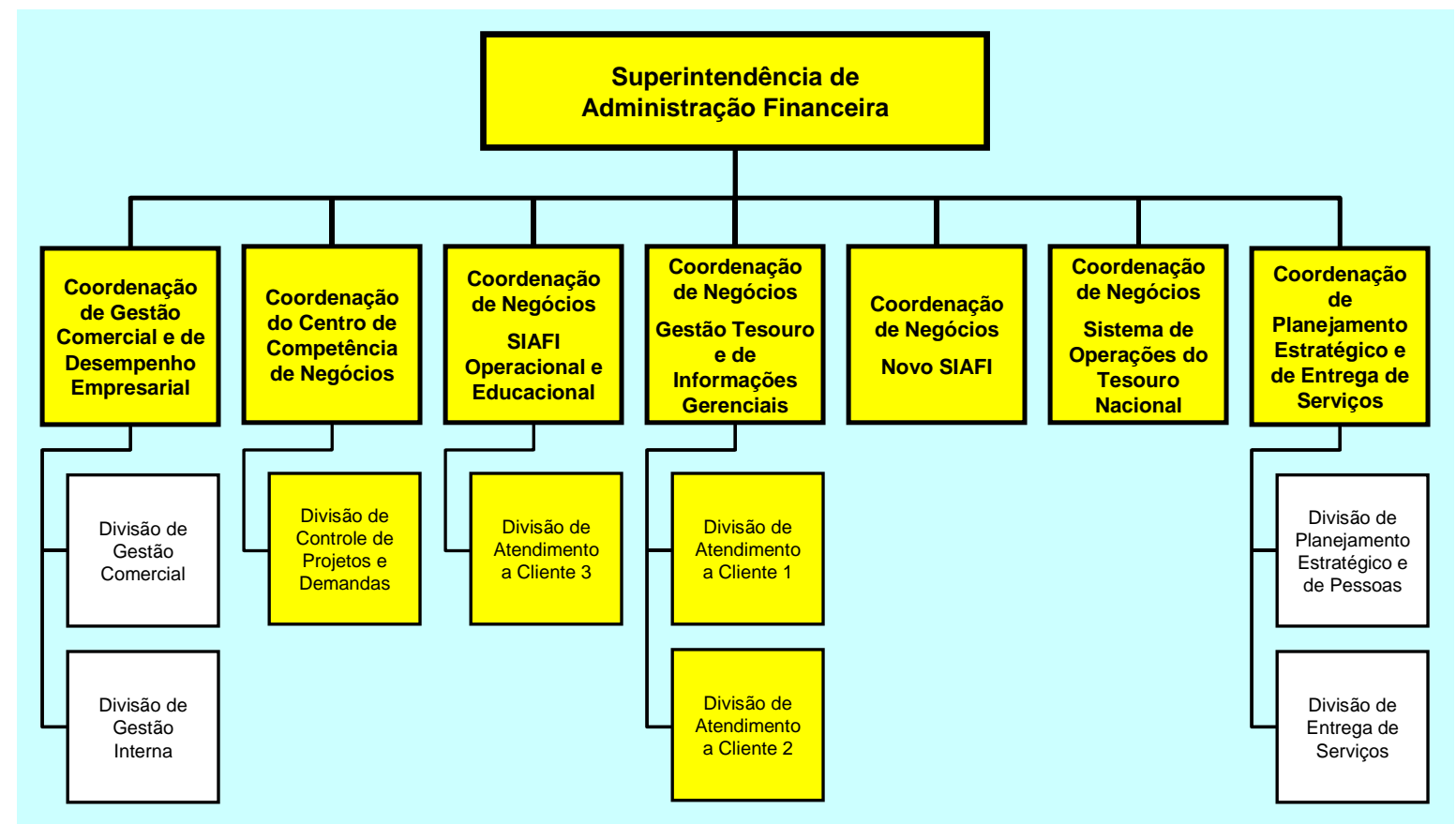

Figura 4 - Organograma da SUNAF

Fonte: Adaptado pela autora com base na documentação institucional da SUNAF (2009)

\footnotetext{
${ }^{5}$ Serviço Federal de Processamento de Dados - SERPRO é uma empresa pública, vinculada ao Ministério da Fazenda. Foi criada no dia 1을 de dezembro de 1964, pela Lei oㅜ 4.516, com o objetivo de modernizar e dar agilidade a setores estratégicos da Administração Pública brasileira. A Empresa, cujo negócio é a prestação de serviços em Tecnologia da Informação e Comunicações para o setor público, é considerada uma das maiores organizações do setor, na América Latina. O SERPRO desenvolve programas e serviços que permitem maior controle e transparência sobre a receita e os gastos públicos, além de facilitar a relação dos cidadãos com o governo.
} 
Segundo Vargas (2006), as inovações podem ser classificadas em quatro tipos: de produto, de processo, organizacional ou gerencial e de mercado. Nesta pesquisa, serão objetos de estudo, especificamente, as inovações de produto de TIC. Desta forma, o termo serviço será usado como relativo ao produto de TIC.

As principais atividades relativas aos serviços de TIC da SUNAF podem ser: i) prospectar novos serviços, ii) propor evoluções de arquitetura serviços (funcional e tecnologicamente) ou, quando esta proposta é demandada pelo cliente, analisar e avaliar as propostas recebidas pelos clientes ou pelos parceiros internos; iii) realizar manutenções evolutivas e corretivas de serviços; iv) gerenciar o processo produtivo dos serviços; e v) negociar com os clientes e fornecedores internos. Neste sentido, vale ressaltar que a SUNAF não trabalha de forma isolada, para realizar as atividades relacionadas, conta com outras áreas, conhecidas como unidades de infra-estrutura, especialistas em diversos segmentos de TIC (rede, centro de dados, desenvolvimento, gestão de serviços etc). A interação com os clientes é realizada por intermédio dos sessenta e quatro ${ }^{6}$ colaboradores da SUNAF.

\subsubsection{Amostragem}

Sem a preocupação de estabelecer uma amostragem estatística dos serviços a serem analisados, a seleção dos mesmos foi orientada pelo objetivo de garantir uma representatividade da análise. $O$ mesmo objetivo orientou a seleção dos sujeitos que participaram da pesquisa.

A amostragem de serviços da investigação foi composta de serviços de TIC em produção sob gestão da SUNAF em abril de 2009, cuja previsão de receita está estimada acima de $R \$ 650.000,00$ (seiscentos e cinqüenta mil reais). Estes serviços representam ${ }^{7} 96,82 \%$, em termos de previsão de receita, dos serviços, e 32,5\% da quantidade de serviços contratados sob gestão da unidade.

O conjunto de participantes da pesquisa foi composto pelos gerentes da superintendência, responsáveis pela gestão de serviços de TIC, que consiste na macro-função de prospecção de novos serviços, gestão comercial, gerenciamento de projetos de desenvolvimento, evolução, manutenção e acompanhamento da 
produção dos serviços.

Como foi citada anteriormente, a SUNAF conta com atuação de outras unidades, denominadas de infra-estrutura, para execução de todo ciclo produtivo necessário para a entrega dos serviços. Porém, são os gerentes da SUNAF que respondem pela prestação de contas e outros posicionamentos, interna e externamente (junto aos clientes, aos patrocinadores, à direção da empresa, aos órgãos de controle e de auditoria) sobre os serviços. Desta forma, os gerentes da SUNAF possuem vasto conhecimento não só em TIC, mas também, no segmento orçamentário e financeiro do Governo Federal.

A pesquisa envolveu $75 \%$ dos gerentes da SUNAF, incluindo a observaçãoparticipante da autora da pesquisa que faz parte do corpo gerencial da superintendência. Totalizou-se, assim, a participação de doze gerentes. Na sua maioria, estes gerentes têm histórico de atuação exclusiva no segmento de TIC para o Governo, apresentando tempo médio de atuação neste segmento como técnico de 20,3 anos, como técnico no setor público de 19 anos e como gerente de 9,8 anos.

3.3. Instrumento de coleta de dados

Segundo Yin (2005) os instrumentos de coletas de dados, ou fontes de evidências, podem ser categorizadas em seis tipos, conforme ilustrado no Quadro 4.

\begin{tabular}{|c|c|c|}
\hline $\begin{array}{l}\text { Fonte de } \\
\text { evidências }\end{array}$ & Pontos Fortes & Pontos fracos \\
\hline Documentação & $\begin{array}{l}\text { - Estável: podem ser revisadas inúmeras } \\
\text { vezes; } \\
\text { - Discreta: não foi criada como resultado } \\
\text { do estudo de caso; } \\
\text { - Exata: contém nomes, referências e } \\
\text { detalhes exatos de um evento; } \\
\text { - Ampla cobertura: longo espaço de } \\
\text { tempo, muitos eventos e muitos } \\
\text { ambientes distintos. }\end{array}$ & $\begin{array}{l}\text { - Capacidade de recuperação: pode } \\
\text { ser baixa; } \\
\text { - Seletividade tendenciosa, se a } \\
\text { coleta não estiver completa; } \\
\text { - Relato de vieses: reflete as idéias } \\
\text { preconcebidas do autor; } \\
\text { - Acesso: pode ser deliberadamente } \\
\text { negado. }\end{array}$ \\
\hline $\begin{array}{l}\text { Registros em } \\
\text { arquivos }\end{array}$ & $\begin{array}{l}\text { - (Os mesmos mencionados para } \\
\text { documentação); } \\
\text { - Precisos e quantitativos. }\end{array}$ & $\begin{array}{l}\text { - (Os mesmos mencionados para } \\
\text { documentação); } \\
\text { - Acessibilidade aos locais devido a } \\
\text { razões particulares. }\end{array}$ \\
\hline
\end{tabular}

\footnotetext{
${ }_{7}^{6}$ Dados de abril de 2009.

${ }^{7}$ Dados de maio de 2009.
} 


\begin{tabular}{|c|c|c|}
\hline $\begin{array}{l}\text { Fonte de } \\
\text { evidências }\end{array}$ & Pontos Fortes & Pontos fracos \\
\hline Entrevistas & $\begin{array}{l}\text { - Direcionadas: enfocam diretamente o } \\
\text { tópico do estudo de caso; } \\
\text { - Perceptivas: fornecem interferências } \\
\text { casuais percebidas. }\end{array}$ & $\begin{array}{l}\text { - Vieses devido a questões mal- } \\
\text { elaboradas; } \\
\text { - Respostas viesadas; } \\
\text { - Ocorrem imprecisões devido à } \\
\text { memória fraca do entrevistado; } \\
\text { - Reflexibilidade: o entrevistado dá } \\
\text { ao entrevistador o que ele quer } \\
\text { ouvir. }\end{array}$ \\
\hline $\begin{array}{l}\text { Observações } \\
\text { diretas }\end{array}$ & $\begin{array}{l}\text { - Realidade: tratam de acontecimentos } \\
\text { em tempo real; } \\
\text { - Contextuais: tratam do contexto do } \\
\text { evento. }\end{array}$ & $\begin{array}{l}\text { - Consomem muito tempo } \\
\text { seletivamente, salvo ampla } \\
\text { cobertura; } \\
\text { - Reflexibilidade: o acontecimento } \\
\text { pode ocorrer de forma diferenciada } \\
\text { porque está sendo observado; } \\
\text { - Custo: horas necessárias pelos } \\
\text { observadores humanos. }\end{array}$ \\
\hline $\begin{array}{l}\text { Observações } \\
\text { participantes }\end{array}$ & $\begin{array}{l}\text { - (Os mesmos mencionados para } \\
\text { observação direta); } \\
\text { - Perceptiva em relação a comportamento } \\
\text { e razões interpessoais. }\end{array}$ & $\begin{array}{l}\text { - (Os mesmos mencionados para } \\
\text { observação direta); } \\
\text { - Vieses devido à manipulação dos } \\
\text { eventos por parte do pesquisador. }\end{array}$ \\
\hline $\begin{array}{l}\text { Artefatos } \\
\text { físicos }\end{array}$ & $\begin{array}{l}\text { - Capacidade de percepção em relação a } \\
\text { aspectos culturais; } \\
\text { - Capacidade de percepção em relação a } \\
\text { operações técnicas. }\end{array}$ & $\begin{array}{l}\text { - Seletividade; } \\
\text { - Disponibilidade. }\end{array}$ \\
\hline
\end{tabular}

Quadro 4 - Fontes de evidências: pontos fortes e pontos fracos.

Fonte: Yin (2005, p. 113).

Com base na análise das informações do Quadro 4, nesta pesquisa, foram adotados os seguintes instrumentos:

a) Documentação: contratos firmados com os clientes, Relatórios de previsão de faturamento dos serviços, Diário Executivo da SUNAF, Resumo Executivos das Coordenações, Relatórios do Escritório de Projetos da SUNAF.

b) Registros em arquivos: Documentos de Visão do Serviço (DV), Documentos de Arquitetura do Serviço (DAS), registros no Portifólio de Projetos - Sistema e-Car, Planejamento Estratégico Empresarial, Plano Diretor de Tecnologia da Informação (PDTI), Processo de Gerenciamento de Projetos do SERPRO (PGPS), Processo SERPRO de Gerenciamento de Serviços (PSGS), Processo SERPRO de Desenvolvimento de Soluções (PSDS) e Programa SERPRO de Segurança (PSS);

c) Entrevistas: entrevistas individuais semi-estruturadas realizadas com os gerentes da SUNAF, com base no roteiro descrito no Apêndice A. A opção pela entrevista semi-estruturada buscou favorecer a exposição do ponto 
de vista do ator entrevistado em relação a sua percepção sobre as implementações de inovações nos serviços sob sua responsabilidade, bem como em relação aos valores públicos agregados.

d) Observação-participante ${ }^{8}$.

Esta coleta de dados foi norteada por cinco blocos temáticos, os quais refletem os blocos de 1 a 5 do roteiro de entrevista, cujas finalidades estão apresentadas no Quadro 5.

\begin{tabular}{|l|l|l|}
\hline \multicolumn{1}{|c|}{ Bloco Temático } & \multicolumn{1}{|c|}{ Objetivo } & $\begin{array}{l}\text { Instrumento de coleta de } \\
\text { dados }\end{array}$ \\
\hline $\begin{array}{l}\text { 1- Identificação do } \\
\text { Entrevistado. }\end{array}$ & Identificar o perfil dos entrevistados. & Entrevista. \\
\hline 2- Origem do Serviço. & $\begin{array}{l}\text { Identificar objetivos, motivação e patrocínio } \\
\text { do serviço. }\end{array}$ & Todos selecionados. \\
\hline 3- Inovações de TIC. & $\begin{array}{l}\text { Identificar e caracterizar as inovações de } \\
\text { TIC agregadas em serviços de TIC. }\end{array}$ & $\begin{array}{l}\text { Registro em arquivos, } \\
\text { Entrevistas e Observação } \\
\text { Participante. }\end{array}$ \\
\hline $\begin{array}{l}4-\text { Caracterização de } \\
\text { inovação em serviços } \\
\text { com foco em valor } \\
\text { público agregado. }\end{array}$ & $\begin{array}{l}\text { Identificar e caracterizar as implementações } \\
\text { de inovações em gestão publica através dos } \\
\text { serviços de TIC. }\end{array}$ & $\begin{array}{l}\text { Entrevistas e Observação } \\
\text { Participante. }\end{array}$ \\
\hline $\begin{array}{l}\text { 5 - Práticas de } \\
\text { aprendizagem visando } \\
\text { inovações futuras. }\end{array}$ & $\begin{array}{l}\text { Identificar se há evidências que assegurem } \\
\text { o processo de aprendizado contínuo e de } \\
\text { instituicionalização do conhecimento } \\
\text { adquirido. }\end{array}$ & $\begin{array}{l}\text { Entrevistas e Observação } \\
\text { Participante }\end{array}$ \\
\hline
\end{tabular}

Quadro 5 - Blocos temáticos para coleta de dados.

Fonte: Elaboração da autora.

\subsection{Procedimentos da coleta de dados}

$\mathrm{Na}$ etapa de coleta de dados, foram planejadas e executas as atividades conforme ilustradas na Figura 5. A estratégia adotada para aprimoramento do resultado final foi de refinamentos sucessivos.

\footnotetext{
${ }^{8} \mathrm{~A}$ autora faz parte do corpo gerencial da SUNAF.
} 


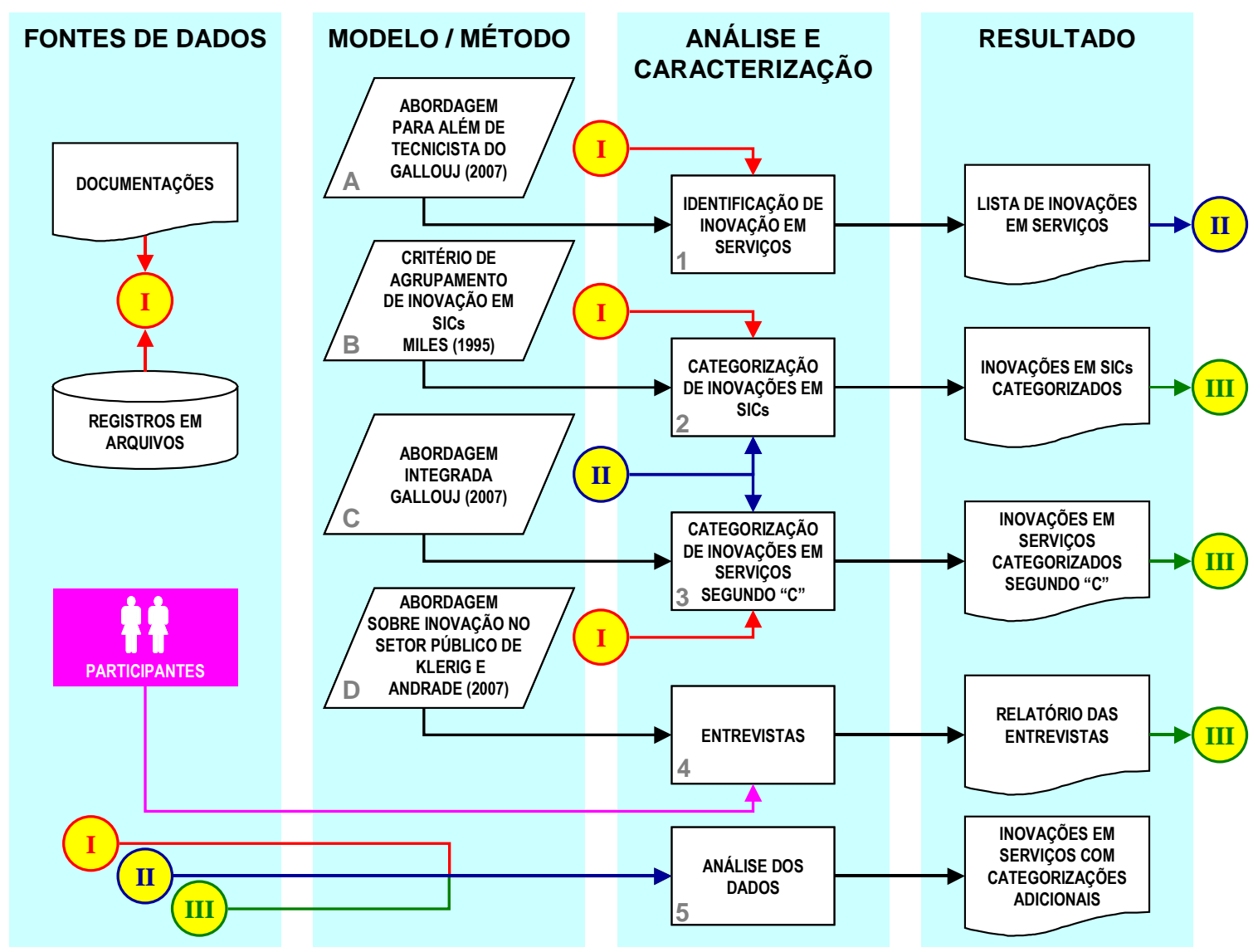

Figura 5 - Diagrama de procedimentos da coleta e análise dos dados Fonte: Elaboração da autora.

\section{a) Identificação de inovações em serviços.}

Nesta etapa, foi obtido uma primeira visão das inovações identificadas nos serviços de TIC selecionados na subseção 3.2.2. , com base na abordagem do Gallouj (2007), descrita como "Abordagem para além da tecnicistas", conforme explorado na subseção 2.2.1. Como fontes de evidência foram utilizados os seguintes instrumentos: documentação, registros em arquivos e observação participante.

\section{b) Caracterização de inovação em serviços pela abordagem integradora}

$O$ resultado da etapa anterior foi submetido a um trabalho de refinamento e de complementação a luz do modelo proposto pelo Gallouj (2007) - Abordagem Integradora, utilizando-se dos mesmos instrumentos, complementados os dados coletados, até então, com novas evidências. 


\section{c) Aplicação das entrevistas}

No período de 06 a 27/04/2009, foram realizadas 12 entrevistas conforme amostra definida na subseção 3.2.2. . As entrevistas foram gravadas, mediante a autorização do entrevistado, e transcritas em uma planilha com a formação estruturada para favorecer a etapa, posterior, de análise. A maioria dos serviços pesquisados teve mais de um entrevistado envolvido.

Todas as entrevistas foram precedidas de uma pequena explanação sobre a pesquisa acadêmica e os conceitos envolvidos, esclarecendo que é garantido sigilo sobre o conteúdo das informações coletadas e o anonimato dos entrevistados. Todos os entrevistados forneceram a sua percepção sobre o processo de inovações dos serviços sob a sua gestão, envolvendo os cinco blocos temáticos, conforme expostos na seção 3.3 .

\subsection{Análise dos Dados}

De acordo com o Yin (2006, p. 137), "análise de dados consiste em examinar, categorizar, classificar em tabelas, testar ou, do contrário, recombinar as evidências quantitativas e qualitativas para tratar as proposições inicias do estudo". Os principais insumos utilizados na análise dos dados estão ilustrados na Figura 5.

Para a análise do conteúdo das informações, obtidas na etapa de coleta dos dados, visando refinamento e consolidação das características das inovações implementadas pelos serviços de TIC da SUNAF, optou-se pela adoção da mesma classificação em blocos temáticos adotado na seção anterior, focando atenção nos blocos temáticos 3 e 4 que estão diretamente ligados ao objeto desta pesquisa.

Para fundamentar a análise do bloco temático 3 , que está centrado em inovação através de TIC, foi utilizada a abordagem integradora da inovação, Gallouj (2007), apresentada na subseção 2.2.4.

Para o bloco temático 4, optou-se pelo modelo de análise dos atributos de inovação em gestão pública de Klering e Andrade (2005), centrada na identificação dos valores públicos agregados pelos serviços de TIC. A importância desta abordagem é justificada pela própria missão da SUNAF em prover serviços de TIC que apóie a implementação de políticas públicas. 
$\mathrm{Na}$ aplicação do modelo do Klering e Andrade (2005), foram feitas algumas adequações pela autora para adequar ao escopo da sua pesquisa, as quais estão descritas e justificadas, a seguir:

- Os autores associam os atributos diretamente aos projetos e não aos serviços. Considerando que um serviço é, na sua essência, um projeto implementado, entendeu-se que é válida a aplicação deste método em análise de inovação em serviços.

- Os autores apresentam um conjunto de 20 atributos. Dentre estes, quatro não foram utilizadas nesta pesquisa, conforme justificado no Quadro 6.

\begin{tabular}{|l|l|}
\hline \multicolumn{1}{|c|}{$\begin{array}{c}\text { Características e } \\
\text { Atributos }\end{array}$} & \multicolumn{1}{c|}{ Justificativa } \\
\hline $\begin{array}{l}\text { Melhoria da qualidade de } \\
\text { vida do público-alvo }\end{array}$ & $\begin{array}{l}\text { Pela descrição do atributo não se aplica aos serviços de TIC prestados } \\
\text { pela SUNAF. }\end{array}$ \\
\hline Auto-sustentabilidade & $\begin{array}{l}\text { Todos os serviços de TIC prestados pela SUNAF, não são auto- } \\
\text { sustentáveis e são pagos pela STN. }\end{array}$ \\
\hline $\begin{array}{l}\text { Viabilidade técnica, } \\
\text { gerencial, econômica e } \\
\text { financeira }\end{array}$ & $\begin{array}{l}\text { Como não são projetos, são serviços em produção, as viabilidades sob } \\
\text { estes aspectos estão comprovadas. }\end{array}$ \\
\hline $\begin{array}{l}\text { Inclusão de minorias } \\
\text { sociais }\end{array}$ & $\begin{array}{l}\text { Pela descrição do atributo não se aplica aos serviços de TIC prestados } \\
\text { pela SUNAF }\end{array}$ \\
\hline
\end{tabular}

Quadro 6 - Características e atributos excluído da análise

Fonte: Elaboração da autora.

- Os autores, em alguns dos atributos, focam a sociedade como público alvo. Esta situação acontece quando o público alvo do serviço não é os cidadãos em si, e sim conjunto de atores com perfis relacionados com as atividades apoiadas pelo serviço de TIC. Nestes casos, a pesquisa focou para o efetivo público alvo do serviço. Entendeu-se que esta adaptação é válida, mantendose como proposto os atributos ligados à comunicação e articulação entre o governo e diversos entes e setores, incluindo a sociedade civil.

- A autora optou em incluir um novo atributo Compliance, que serve para avaliar se o serviço está em conformidade com as leis, normas e os procedimentos institucionais vigentes ${ }^{9}$. Uma vez que todos os serviços da amostra apóiam os serviços públicos que, diretamente ou indiretamente,

\footnotetext{
${ }^{9}$ Segundo a Norma Australiana AS 3806, edição 2006, compliance é o atendimento a requisitos de leis, normas e códigos organizacionais e da indústria, bem como a princípios de boa governança e padrões comunitários e éticos, normalmente aceitos. São exemplos de compliance o atendimento à Lei Sarbanes-Oxley, à legislação ambiental, às Normas Regulamentadoras de Segurança e Saúde no Trabalho, ao Código de Defesa do Consumidor, à ISO 9001 etc.
} 
viabilizam as políticas públicas, entendeu-se que é um atributo relevante para ser considerado nesta pesquisa.

No capítulo a seguir, são apresentados os resultados obtidos, os quais foram submetidos à análise, à luz dos modelos teóricos aplicados nesta pesquisa. 


\section{APRESENTAÇÃO E ANÁLISE DOS RESULTADOS}

Neste capítulo são apresentados e analisados os resultados da pesquisa qualitativa que tem como objetivo identificar e caracterizar o processo de inovação em serviços de TIC na SUNAF. A abordagem do tema é realizada com base nos blocos temáticos 2 a 5, descritos na subseção 3.3.

Para contextualização do escopo dos serviços de TIC selecionadas para a pesquisa, na seção a seguir apresenta-se uma breve descrição dos serviços selecionados.

\subsection{Descrição dos serviços de TIC selecionados}

Conforme relatada na subseção 3.2.2. , a amostra conta com os serviços de TIC da SUNAF que atendem aos argumentos de seleção estabelecidos para esta pesquisa. Desta forma, foram selecionados os treze serviços que apresentam maior previsão de receita, os quais serão introduzidos com uma breve descrição no Quadro 7.

\begin{tabular}{|c|c|}
\hline Serviços de TIC & Descrição \\
\hline \multicolumn{2}{|r|}{ Serviços Transacionais } \\
\hline SIAFI Operacional & $\begin{array}{l}\text { O SIAFI é o principal instrumento utilizado para registro, } \\
\text { acompanhamento e controle da execução orçamentária, financeira e } \\
\text { patrimonial do Governo Federal. Desde sua criação, o SIAFI tem } \\
\text { alcançado satisfatoriamente seus principais objetivos: } \\
\text { a) Prover mecanismos adequados ao controle diário da execução } \\
\text { orçamentária, financeira e patrimonial aos órgãos da } \\
\text { Administração Pública; } \\
\text { b) Fornecer meios para agilizar a programação financeira, otimizando } \\
\text { a utilização dos recursos do Tesouro Nacional, através da } \\
\text { unificação dos recursos de caixa do Governo Federal; } \\
\text { c) Permitir que a contabilidade pública seja uma fonte segura e } \\
\text { tempestiva de informações gerenciais destinadas a todos os níveis } \\
\text { da Administração Pública Federal; } \\
\text { d) Padronizar métodos e rotinas de trabalho relativas à gestão dos } \\
\text { recursos públicos, sem implicar rigidez ou restrição a essa } \\
\text { atividade, uma vez que ele permanece sob total controle do } \\
\text { ordenador de despesa de cada unidade gestora; } \\
\text { e) Permitir o registro contábil dos balancetes dos estados e } \\
\text { municípios e de suas supervisionadas; }\end{array}$ \\
\hline
\end{tabular}




\begin{tabular}{|c|c|}
\hline Serviços de TIC & Descrição \\
\hline & $\begin{array}{l}\text { f) Permitir o controle da dívida interna e externa, bem como o das } \\
\text { transferências negociadas; } \\
\text { g) Integrar e compatibilizar as informações no âmbito do Governo } \\
\text { Federal; } \\
\text { h) Permitir o acompanhamento e a avaliação do uso dos recursos } \\
\text { públicos; e } \\
\text { h) Proporcionar a transparência dos gastos do Governo Federal. } \\
\text { Na prática, o SIAFI representa um complexo de diversos sistemas } \\
\text { integrados que atuam no segmento orçamentário e financeiro do } \\
\text { Governo Federal. O sistema disponibiliza cerca de } 680 \text { serviços no seu } \\
\text { menu de opções para os usuários e, ainda, cerca de } 350 \text { serviços back } \\
\text { office, conhecidos como serviços batch, que fazem parte do seu } \\
\text { processo produtivo. }\end{array}$ \\
\hline $\begin{array}{l}\text { Sistema de Mensageria do } \\
\text { Tesouro Nacional }\end{array}$ & $\begin{array}{l}\text { O sistema fornece um conjunto de serviços que possibilita à STN } \\
\text { atuar, de forma autônoma, como participante direto do Sistema de } \\
\text { Transferência de Reservas (STR) e prestador de serviços na Rede do } \\
\text { Sistema Financeiro Nacional (RSFN) e, responsável pelo } \\
\text { monitoramento de seus lançamentos e recebimentos. É um serviço de } \\
\text { missão crítica para a Secretaria visto que numa eventual } \\
\text { indisponibilidade do sistema, a União fica impedida de realizar } \\
\text { pagamentos e repasses financeiros da arrecadação. }\end{array}$ \\
\hline Dívida Ativa do Tesouro & $\begin{array}{l}\text { O sistema fornece um conjunto de serviços que apóia a inscrição e o } \\
\text { controle da dívida ativa, regulamentada a partir da legislação } \\
\text { pertinente, abrange os créditos a favor da Fazenda Pública, cuja } \\
\text { certeza e liquidez foram apuradas, por não terem sido efetivamente } \\
\text { recebidos nas datas aprazadas, tendo como principais funcionalidades } \\
\text { inscrição de contratos das dívidas ativa da União e consulta da } \\
\text { inadimplência de contrato à Procuradoria-Geral da Fazenda Nacional } \\
\text { (PGFN). }\end{array}$ \\
\hline Dívida Pública Interna & $\begin{array}{l}\text { O sistema fornece um conjunto de serviços para realização do cálculo, } \\
\text { emissão e pagamento de títulos da Dívida Pública Interna (DPI) com } \\
\text { seus respectivos instrumentos de gestão. Os procedimentos e rotinas } \\
\text { evidenciados da DPI objetivam uma administração mais eficiente de } \\
\text { todos os tipos de título, controlando o fluxo de vida dos ativos desde a } \\
\text { emissão até os pagamentos. }\end{array}$ \\
\hline Extração & $\begin{array}{l}\text { Serviço destinado à realização de extrações e transferências de } \\
\text { arquivos que envolvem grande volume de dados do SIAFI Operacional, } \\
\text { de caráter contínuo, com periodicidade pré-definida pelo cliente. } \\
\text { Os dados a serem extraídos podem ser personalizados, a partir de } \\
\text { modelos de dados específicos para carga inicial de exercícios e } \\
\text { modelos incrementais (movimentações diárias), e no serviço de } \\
\text { transporte dos dados extraídos, diretamente para máquina servidora } \\
\text { dos clientes, de forma segura e gerenciada, entre as máquinas } \\
\text { servidoras ou em outras mídias definidas pelo cliente, onde, } \\
\text { normalmente, complementa um banco de dados de serviços } \\
\text { específicos de tratamento de informações pelos clientes. } \\
\text { É um serviço back office, executado em processos batch, não } \\
\text { possuindo interação com os usuários. A interação é realizada entre } \\
\text { serviço origem e serviço destino. }\end{array}$ \\
\hline $\begin{array}{l}\text { Sistema de Transferência de } \\
\text { Arquivos }\end{array}$ & $\begin{array}{l}\text { Serviço destinado à realização de extrações e transferências de } \\
\text { arquivos que não envolvem grande volume de dados do SIAFI } \\
\text { Operacional. O usuário interage com o sistema, disponibilizado em } \\
\text { web, definindo os dados a serem extraídos podendo programar a } \\
\text { execução do serviço, definindo a periodicidade. Na data definida o } \\
\text { sistema executa o serviço e disponibiliza os dados extraídos para o } \\
\text { usuário. }\end{array}$ \\
\hline
\end{tabular}




\begin{tabular}{|c|c|}
\hline Serviços de TIC & Descrição \\
\hline Manual SIAFI Web & $\begin{array}{l}\text { Sistema oferece informações (metadados) sobre o SIAFI, } \\
\text { apresentando desde os conceitos dos dados e informações até as } \\
\text { normas e procedimentos para utilização dos serviços (transações } \\
\text { SIAFI) pelos atores responsáveis pela gestão e execução do } \\
\text { orçamento e finanças do Governo Federal. É composto, basicamente, } \\
\text { por dois subsistemas: } \\
\text { 1) Subsistema de Consulta: permite acesso às informações sobre o } \\
\text { SIAFI por todas as pessoas através da web; } \\
\text { 2) Subsistema de Gestão: serviço destinado aos gestores da STN, } \\
\text { responsáveis pela gestão do conteúdo do manual. }\end{array}$ \\
\hline Portal SIAFI & $\begin{array}{l}\text { É um ambiente virtual que reúne serviços e informações, com } \\
\text { interação e dinamismo para toda a comunidade SIAFI, que } \\
\text { compreende os usuários operadores, executivos do Governo, } \\
\text { cadastradores de habilitação, profissionais ou entidades de áreas } \\
\text { afins, estudantes, sociedade, dentre outros públicos a serem } \\
\text { atendidos. Os serviços e informações a serem oferecidos têm como } \\
\text { fonte de informação os sistemas SIAFI Operacional e o SIAFI } \\
\text { Gerencial. O portal oferece, ainda, as funcionalidades de busca em } \\
\text { páginas HTML }{ }^{10} \text { e disponibilização de enquetes na página inicial. }\end{array}$ \\
\hline Portal Tesouro & $\begin{array}{l}\text { Serviço, na web, oferece um ambiente virtual que reúne serviços e } \\
\text { informações sobre atuação da STN, tais como: Instituição STN, SIAFI, } \\
\text { Tesouro Direto e Tesouro no Sistema de Pagamentos Brasileiro (SPB). } \\
\text { Através deste portal, a sociedade tem acesso aos serviços e } \\
\text { informações atualizadas sobre diversos segmentos de atuação da } \\
\text { STN. É um importante espaço de interação entre a STN e a sociedade. }\end{array}$ \\
\hline \multicolumn{2}{|r|}{ Serviços de apoio à decisão } \\
\hline DW Sintese & $\begin{array}{l}\text { Sistema de apoio à decisão, com foco na auditoria, disponibiliza um } \\
\text { conjunto de funcionalidade para tratamento de dados e geração de } \\
\text { informações, para suporte às atividades de controle externo da União } \\
\text { e das entidades da administração direta e indireta, mediante } \\
\text { fiscalização contábil, financeira, orçamentária, operacional e } \\
\text { patrimonial dos recursos públicos realizadas pelo TCU. Para tanto, } \\
\text { reúnem em um único repositório os dados oriundos de diversas bases } \\
\text { de dados mantidas pela Administração Federal: SIAFI Operacional, } \\
\text { Sistema Integrado de Administração de Serviços Gerais (SIASG), } \\
\text { Sistema Integrado de Administração de Recursos Humanos (SIAPE) e } \\
\text { sistemas Internos do TCU. } \\
\text { A arquitetura da solução é baseada de tecnologia data warehouse } \\
\text { (DW), especializada em sistema de informações de apoio à decisão. }\end{array}$ \\
\hline DW Pagamento Efetivo & $\begin{array}{l}\text { Sistema de apoio à decisão, com foco na gestão e no controle, } \\
\text { disponibiliza um conjunto de funcionalidade para tratamento de dados } \\
\text { e geração de informações, para suporte ao gerenciamento do fluxo de } \\
\text { caixa do Governo Federal. Os dados são oriundos do SIAFI } \\
\text { Operacional, especificamente, referente à execução financeira. } \\
\text { A arquitetura da solução é baseada de tecnologia DW, especializada } \\
\text { em sistema de informações de apoio à decisão. }\end{array}$ \\
\hline DW BGU & $\begin{array}{l}\text { O sistema apóia a elaboração do Balanço Geral da União (BGU) } \\
\text { realizada pelos contadores da STN. Para tanto, fornece um conjunto } \\
\text { de funcionalidade para geração e tratamento de informações de forma } \\
\text { parametrizada, flexibilizando e facilitando o processo de elaboração } \\
\text { do BGU pelos gestores, sem a necessidade de auxílio dos } \\
\text { especialistas em tecnologia. O BGU demonstra as principais ações } \\
\text { governamentais executadas pelos órgãos e entidades da } \\
\text { Administração Pública Federal vinculada ao Poder Executivo, bem } \\
\text { como a execução dos Orçamentos Fiscal, da Seguridade Social e de }\end{array}$ \\
\hline
\end{tabular}

${ }^{10}$ HyperText Markup Language (HTML), que significa Linguagem de Marcação de Hipertexto é uma linguagem de marcação utilizada para produzir nas páginas web. Documentos HTML podem ser interpretados por navegadores. 


\begin{tabular}{|l|l|}
\hline \multicolumn{1}{|c|}{ Serviços de TIC } & \multicolumn{1}{c|}{ Descrição } \\
\hline & $\begin{array}{l}\text { Investimento das Empresas Estatais. Os dados são oriundos do SIAFI } \\
\text { Operacional. } \\
\text { Também, oferece um serviço de consulta aos dados do BGU pelos } \\
\text { cidadãos pela web. } \\
\text { A arquitetura da solução é baseada de tecnologia data warehouse, } \\
\text { especializada em sistema de informações de apoio à decisão. }\end{array}$ \\
\hline SIAFI Gerencial & $\begin{array}{l}\text { O SIAFI Gerencial é uma ferramenta de suporte à decisão para os } \\
\text { gestores públicos em ambiente gráfico, com funcionalidades que } \\
\text { facilitam a elaboração de informações gerenciais baseado nos dados } \\
\text { de execução orçamentária, financeira e patrimonial gerados a partir da } \\
\text { base de dados do SIAFI Operacional. Permite o acompanhamento e o } \\
\text { controle da execução orçamentária, financeira e contábil do Governo } \\
\text { Federal. }\end{array}$ \\
\hline
\end{tabular}

Quadro 7 - Descrição dos serviços de TIC pesquisados

Fonte: Elaboração da autora.

Para orientar a análise dos serviços, nas subseções seguintes, os serviços foram classificados em dois grupos: i) serviços transacionais, cujo foco está em oferecer funcionalidades para apoiar as atividades técnicos e operacionais; e ii) serviços de apoio à decisão, cujo foco é apoiar as atividades gerenciais, com funcionalidades para tratamento de informações para a tomada de decisão.

\subsection{Origem das inovações em serviços de TIC}

Todos os serviços de TIC implementados pela SUNAF são realizados mediante um contrato específico de prestação de serviços. $\mathrm{Na}$ totalidade dos serviços de TIC pesquisados foi verificado que, conforme o Quadro 8, tanto o papel do patrocinador como do cliente são representados por uma mesma entidade pública que, respectivamente, utiliza-se do seu orçamento de TIC.

\begin{tabular}{|l|c|c|}
\hline \multicolumn{1}{|c|}{ Patrocinador } & Cliente & $\begin{array}{c}\text { Qdade Serviços } \\
\text { de TIC }\end{array}$ \\
\hline Ministério da Fazenda & STN & 1 \\
\hline SERPRO e STN & STN & 1 \\
\hline STN & STN & 10 \\
\hline TCU & TCU & 1 \\
\hline
\end{tabular}

Quadro 8 - Demonstrativo de patrocinadores e clientes dos serviços

Fonte: Elaboração da autora. 
No universo da amostra, verificaram-se duas exceções descritas a seguir:

a) Sistema de Administração Financeira do Governo Federal (SIAFI Operacional, conhecido simplesmente como SIAFI): a decisão pelo desenvolvimento e operacionalização deste serviço acontece, praticamente no mesmo instante, com a criação da Secretaria do Secretaria do Tesouro Nacional (STN) no Ministério da Fazenda. O SIAFI entrou em operação em janeiro de 1987, um ano após a criação da STN e transforma-se em um dos principais, senão o principal instrumento de gestão orçamentária e financeira do país.

b) Sistema de Mensageria do Tesouro Nacional: o serviço foi proposto pelo SERPRO para a STN. Após negociações, foi estabelecida a parceria para a sua implementação entre estas duas entidades.

A identificação da necessidade dos serviços de TIC é feita, em sua maioria, pelo próprio cliente, não a partir de uma proposição do prestador de serviço, conforme exposto no Quadro 9.

\begin{tabular}{|l|c|c|}
\hline $\begin{array}{c}\text { Entidade identificadora } \\
\text { do serviço de TIC }\end{array}$ & Qdade & $\%$ \\
\hline Cliente & 11 & 84,61 \\
\hline SERPRO & 2 & 15,39 \\
\hline
\end{tabular}

Quadro 9 - Demonstrativo da entidade identificadora da necessidade de serviço de TIC

Fonte: Elaboração da autora.

Foi identificado que há um grande volume de demandas dos clientes e usuários por novas funcionalidades e novos serviços, os quais compõem e aumentam, a lista de espera chamada de serviços em back log, cujas razões centrais estão: i) no tamanho do orçamento no cliente disponível para esta destinação; ii) especialistas em negócios no cliente em volume não suficiente para realizar as suas atribuições finalísticas e ainda dedicar-se a novos projetos e especificação de novas funcionalidades ou evoluções de funcionalidades existentes; iii) o SERPRO não possui volume de especialistas, de diversos segmentos de tecnologia e de processos de desenvolvimento e de produção, em número suficiente para atender às demandas de forma tempestiva, exigindo priorizações; iv) o 
processo de aquisição de hardware e software, para viabilizar a operacionalização dos serviços, é regido pela Lei 8666 de 21/06/1993 ${ }^{11}$ que demanda tempo considerável entre início do processo de aquisição e recebimento dos produtos, em que diversos fatos (fornecedores que perderam o processo de licitação pode entrar com recurso para contestar o resultado, não encontrar no mercado fornecedores em número suficiente que atendam aos requisitos do certame, gerando necessidade de ajustes dos requisitos projeto básico etc) podem impactar na entrega dos serviços de TIC.

Neste aspecto, dentre os serviços de TIC pesquisados, foram identificados os que não visam atender, somente, às necessidades da entidade cliente. Enquadra-se neste caso, por exemplo, o serviço gerido pela STN, o SIAFI Operacional, que é disponibilizado para os gestores e técnicos que atuam ou são partes interessadas no segmento orçamentário e financeiro do Governo Federal, o que significa envolver as possíveis demandas dos seus 65.000 usuários, aproximadamente. Estes pedidos são analisados, sob ótica das necessidades gerais dos órgãos usuários ou específica do órgão solicitante. As necessidades gerais são tratadas com maior prioridade de atendimento. Vale destacar, ainda, que nem todas as demandas dos usuários finais são relativas a evoluções nos sistemas existentes, tratando-se de ajustes de procedimentos e normas que não geram ações de ajustes do serviço de TIC.

Os principais objetivos que levam ao desenvolvimento e operacionalização dos serviços de TIC estão apresentados no Quadro 10.

\begin{tabular}{|c|c|c|c|c|c|c|c|c|c|c|c|c|c|}
\hline \multirow[b]{2}{*}{ Objetivos } & \multicolumn{9}{|c|}{ Serviços Transacionais } & \multicolumn{4}{|c|}{$\begin{array}{l}\text { Serviços de apoio } \\
\text { à decisão }\end{array}$} \\
\hline & 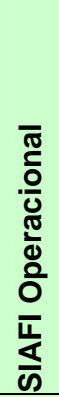 & 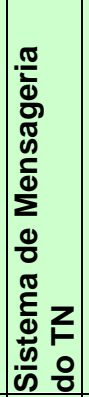 & 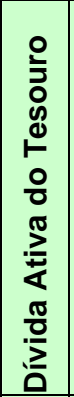 & 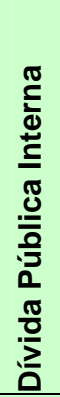 & 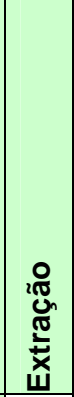 & 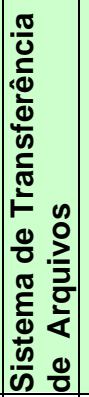 & 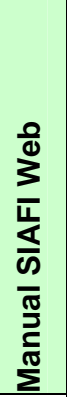 & $\begin{array}{l}\text { एँ } \\
\text { क } \\
\bar{\varpi} \\
\frac{5}{0} \\
0\end{array}$ & 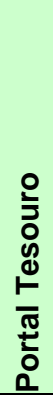 & 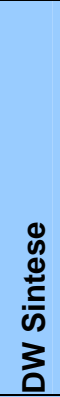 & 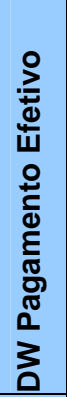 & 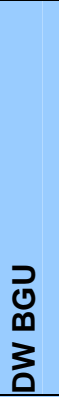 & 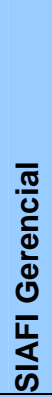 \\
\hline Eficiência no controle & $\mathbf{x}$ & $\mathbf{x}$ & $\mathbf{x}$ & $\mathbf{x}$ & & & & & & $\mathbf{x}$ & $\mathbf{x}$ & $\mathbf{x}$ & $\mathbf{x}$ \\
\hline Eficiência na auditoria & & & & & & & & & & $\mathbf{x}$ & & & \\
\hline
\end{tabular}

${ }^{11}$ A Lei 8666 de 21/06/1993 estabelece normas gerais sobre licitações e contratos administrativos pertinentes a obras, serviços, inclusive de publicidade, compras, alienações e locações no âmbito dos Poderes da União, dos Estados, do Distrito Federal e dos Municípios. 


\begin{tabular}{|c|c|c|c|c|c|c|c|c|c|c|c|c|c|}
\hline \multirow[b]{2}{*}{ Objetivos } & \multicolumn{9}{|c|}{ Serviços Transacionais } & \multicolumn{4}{|c|}{$\begin{array}{l}\text { Serviços de apoio } \\
\text { à decisão }\end{array}$} \\
\hline & 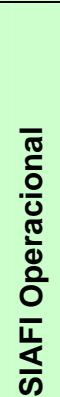 & 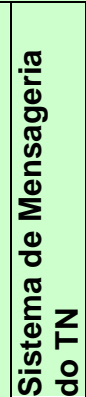 & 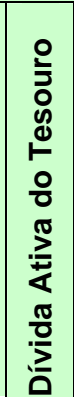 & 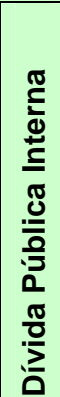 & : & 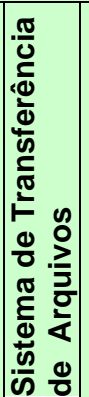 & 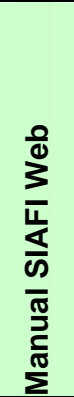 & 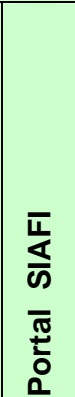 & 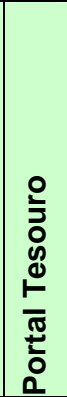 & 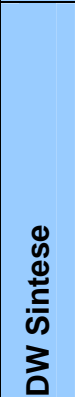 & 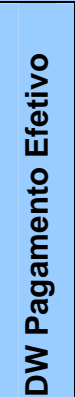 & $\begin{array}{l}\text { ग } \\
\text { m } \\
\text { ב̀ }\end{array}$ & 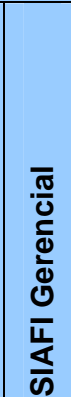 \\
\hline Mitigação de riscos do negócio & $\mathbf{x}$ & $\mathbf{x}$ & $\mathbf{x}$ & $\mathbf{x}$ & & & & & & $\mathbf{x}$ & $\mathbf{x}$ & $\mathbf{x}$ & $\mathbf{x}$ \\
\hline $\begin{array}{l}\text { Instrumentalização de um novo } \\
\text { segmento de atuação do cliente }\end{array}$ & & $\mathbf{x}$ & & & & & & & & & & & \\
\hline $\begin{array}{l}\text { Viabilização de tratamento específico } \\
\text { de dados pelos órgãos }\end{array}$ & & & & & $\mathbf{x}$ & $\mathbf{x}$ & & & & & & & \\
\hline $\begin{array}{l}\text { Eficiência e qualidade da gestão das } \\
\text { contas/finanças públicas }\end{array}$ & $\mathbf{x}$ & $\mathbf{x}$ & $\mathbf{x}$ & $x$ & & & & & & $\mathbf{x}$ & $\mathbf{x}$ & $\mathbf{x}$ & $\mathbf{x}$ \\
\hline $\begin{array}{l}\text { Tornar-se uma fonte segura e } \\
\text { tempestiva de informações } \\
\text { operacionais }\end{array}$ & $\mathbf{x}$ & $\mathbf{x}$ & & & & & & & & & & & \\
\hline $\begin{array}{l}\text { Tornar-se uma fonte segura e } \\
\text { tempestiva de informações gerenciais }\end{array}$ & & & $\mathbf{x}$ & $x$ & & & & & & $\mathbf{x}$ & $\mathbf{x}$ & $\mathbf{x}$ & $\mathbf{x}$ \\
\hline $\begin{array}{l}\text { Padronização e otimização de } \\
\text { métodos e rotinas de trabalho }\end{array}$ & $\mathbf{X}$ & $\mathbf{x}$ & & & & & & & & & & & \\
\hline Garantia dos registros da execução & $\mathbf{x}$ & $\mathbf{x}$ & $\mathbf{x}$ & $\mathbf{x}$ & & & & & & & & & \\
\hline $\begin{array}{l}\text { Integração e compatibilização das } \\
\text { informações. }\end{array}$ & $\mathbf{x}$ & $\mathbf{x}$ & & & & & & & & $\mathbf{x}$ & & & \\
\hline $\begin{array}{l}\text { Acompanhamento e avaliação do uso } \\
\text { dos recursos públicos }\end{array}$ & $\mathbf{x}$ & & & & & & & & & $\mathbf{x}$ & $\mathbf{x}$ & $\mathbf{x}$ & $\mathbf{x}$ \\
\hline $\begin{array}{l}\text { Flexibilização no tratamento de } \\
\text { informações pelos usuários }\end{array}$ & & & & & & & & & & $\mathbf{x}$ & $\mathbf{x}$ & $\mathbf{x}$ & $\mathbf{x}$ \\
\hline $\begin{array}{l}\text { Transparência e publicidade das } \\
\text { ações na área orçamentária e } \\
\text { financeira }\end{array}$ & & & $\mathbf{x}$ & $\mathbf{x}$ & & & $\mathbf{x}$ & $\mathbf{x}$ & $\mathbf{x}$ & $\mathbf{x}$ & & $\mathbf{x}$ & $\mathbf{x}$ \\
\hline $\begin{array}{l}\text { Fornecimento de informações sobre } \\
\text { os serviços do SIAFI Operacional }\end{array}$ & & & & & & & $\mathbf{x}$ & & & & & & \\
\hline Fornecimento de serviços ao público ${ }^{12}$ & & & & & & & & & $\mathbf{x}$ & & & & \\
\hline
\end{tabular}

Quadro 10 - Demonstrativo dos principais objetivos por tipo de serviços de TIC Fonte: Elaboração da autora.

Conforme destacado no Quadro 10, nota-se um certo padrão nos objetivos que norteiam a implementação dos serviços transacionais e dos serviços de apoio à decisão.

Os serviços transacionais estão fortemente concentrados na eficiência no controle e na auditoria, na mitigação dos riscos de negócio, eficiência na qualidade da gestão de contas e finanças públicas e na garantias dos registros de execução. As razões dos quatro serviços transacionais que não apresentam esses objetivos

\footnotetext{
${ }^{12}$ Exemplo: venda de títulos públicos
} 
estão descritas a seguir:

a) Extração e Sistema de Transferência de Arquivos: estes serviços visam oferecer uma maior flexibilidade e liberdade para tratamento dos dados registrados no SIAFI Operacional pelos órgãos. Conforme citado anteriormente, a STN, não tem condição de atender às necessidades específicas de cada órgão. Assim, a partir destes serviços, os órgãos podem definir os dados que desejam receber e a periodicidade de recebimento, carregá-los na sua base de dados e realizar o tratamento para geração de informações úteis para o processo de tomada de decisão daquele órgão. Segundo o entrevistado, "...os órgãos buscam ter melhor sistema de informações para tomar melhores decisões". Em relação aos sistemas destinatários, os serviços de extração e de transferência de arquivos podem ser classificados como de back office.

b) Manual SIAFI: o objetivo do serviço é, basicamente, fornecer informações sobre SIAFI Operacional e as leis e normas que regem este serviço, para todo público que tiver interesse em conhecê-lo.

c) Portal SIAFI: este serviço visa fornecer informações sobre a execução orçamentária e financeira do Governo Federal, registradas no SIAFI Operacional, ao público em geral.

d) Portal Tesouro: este serviço visa oferecer visibilidade e transparência sobre a instituição STN para o público em geral. Conforme citado pelo entrevistado, "o serviço dota a STN de um serviço, em um ambiente web, permitindo o acompanhamento e transparência de suas atividades por toda a sociedade, pela internet'.

Os sistemas de informações que implementam os serviços de TIC, para atender a área patrimonial, orçamentária e financeira do Governo Federal, fazem parte dos principais instrumentos para viabilização de políticas públicas. Todos os entrevistados foram unânimes em confirmar esta visão, havendo um destaque diferenciado em relação a atenção em uma ou mais determinadas políticas pública. Conforme entrevistado, 
... existiram e existem em ênfases diversas, em função da própria alternância de mando no Governo Federal. No governo FHC, houve ênfase com o governo eletrônico. Atualmente, o governo foca no dispêndio dos órgãos públicos com as despesas vinculada às TIC.

Tratando-se dos serviços de TIC do Governo, identifica-se a necessidade de alinhamento com a política de Governo Eletrônico que define um conjunto de diretrizes que atua em três frentes fundamentais: junto ao cidadão; na melhoria da sua própria gestão interna; e na integração com parceiros e fornecedores. De acordo com entrevistado,

\footnotetext{
O que se pretende com o Programa de Governo Eletrônico brasileiro é a transformação das relações do Governo com os cidadãos, empresas e também entre os órgãos do próprio governo de forma a aprimorar a qualidade dos serviços prestados; promover a interação entre empresas e indústrias; e fortalecer a participação cidadã por meio do acesso à informação e a uma administração mais eficiente.
}

Para análise do público alvo, utilizou-se da classificação proposta por Klering e Andrade (2006), baseada na tabela de lista de atributos de projetos inovadores no setor público, obtendo-se o Quadro 10. Neste quadro identifica-se que o SIAFI Operacional oferece alguns serviços ao público de forma indireta. Isso ocorre, por exemplo, nos seguintes serviços: i) Guia de Recolhimento da União (GRU), no Portal SIAFI na internet, qualquer pessoa pode realizar um recolhimento à União. O serviço está integrado ao serviço bancário, no Banco do Brasil (BB) e com o SIAFI Operacional. De modo que, apesar de o ator não ver o SIAFI, ele estará interagindo com o serviço back office deste sistema; ii) é um serviço oferecido pelo Governo Federal à população de baixa renda para custear tratamento de saúde em uma outra localidade, na ausência do tratamento necessário no local de origem do beneficiado. A partir de um comando do gestor no SIAFI, o depósito bancário é realizado em nome do beneficiário e uma notificação é encaminhada para ele. 


\section{Legenda:}

D: público que interage diretamente com o serviço

I: público interage indiretamente com o serviço

\begin{tabular}{|c|c|c|c|c|c|c|c|c|c|c|c|c|}
\hline \multirow[b]{2}{*}{ Classificação dos potenciais públicos } & \multicolumn{8}{|c|}{ Serviços Transacionais } & \multicolumn{4}{|c|}{$\begin{array}{l}\text { Serviços de apoio } \\
\text { à decisão }\end{array}$} \\
\hline & 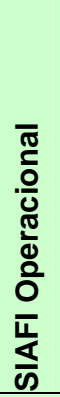 & 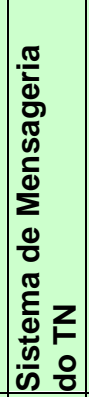 & 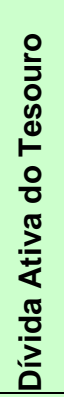 & 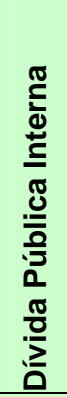 & 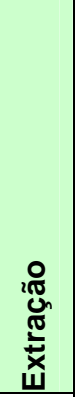 & 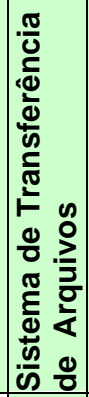 & 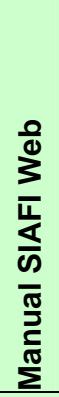 & $\begin{array}{l}\overline{\frac{\pi}{5}} \\
\text { क } \\
\frac{\pi}{2} \\
\frac{5}{0}\end{array}$ & 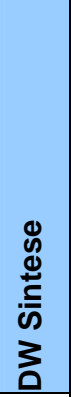 & 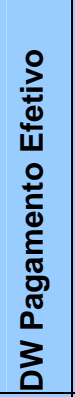 & $\begin{array}{l}\text { D } \\
\text { m } \\
z_{0}^{2}\end{array}$ & 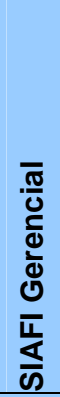 \\
\hline $\begin{array}{l}\text { Agentes e gestores responsáveis pela } \\
\text { execução orçamentária e financeira } \\
\text { do Governo Federal }\end{array}$ & D & D & $\mathbf{D}$ & D & & D & D & D & & D & D & $\mathbf{D}$ \\
\hline $\begin{array}{l}\text { Agentes e gestores responsáveis pelo } \\
\text { controle externo da União e das } \\
\text { entidades da administração direta e } \\
\text { indireta do Governo Federal }\end{array}$ & & & & & & D & & & D & & & \\
\hline $\begin{array}{l}\text { Agentes e gestores responsáveis pela } \\
\text { execução orçamentária e financeira } \\
\text { do Governo Estadual }\end{array}$ & D & & & & & & D & D & & & & \\
\hline $\begin{array}{l}\text { Agentes e gestores responsáveis pela } \\
\text { execução orçamentária e financeira } \\
\text { do Governo Municipal }\end{array}$ & D & - & - & - & - & - & D & D & - & - & - & - \\
\hline Atores da sociedade civil & I & - & - & - & - & - & D & D & - & - & - & - \\
\hline Atores de diferentes setores sociais & I & - & - & - & - & - & D & D & - & - & - & - \\
\hline $\begin{array}{l}\text { Atores, grupos, coletivos e segmentos } \\
\text { sociais. }\end{array}$ & $\mathbf{I}$ & - & - & - & - & - & D & D & - & - & - & - \\
\hline
\end{tabular}

Quadro 11 - Demonstrativo do público alvo por serviços de TIC

Fonte: Elaboração da autora.

Os serviços de TIC no âmbito do Governo Federal atingem os três níveis: i) Governo para Governo (G2G), por meio do SIAFI, por exemplo, o Governo Federal faz interação com entidade na esfera federal, estadual e municipal; ii) Governo para Negócio (G2B), por meio do SPB, por exemplo, a STN realiza negócio com instituições financeiras e câmaras de compensação; e iii) Governo para Cidadão (G2C), dando transparência aos desembolsos realizados pelo governo, por exemplo. Conforme ilustrados no Quadro 11, os serviços pesquisados atingem, na sua maioria, o nível G2G, com pouca expressão nos demais níveis. Dentro deste escopo, destaca-se o SIAFI Operacional, como o sistema estruturante do Governo Federal, com maior amplitude e volume de público alvo, atendendo os diversos perfis de usuários, de setores públicos, privados e a sociedade. 


\subsection{Caracterização da inovação em serviço de TIC}

Para caracterização da inovação em serviços de TIC foi adotado o modelo de abordagem integradora do Gallouj (2007). Conforme descrito na subseção 2.2.4. , o modelo propõem representar as inovações em um conjunto de vetores de características ou de competências, onde: i) [Y] representa as características de serviços, os valores de uso, as utilidades fornecidas ao cliente; ii) [T] corresponde às características técnicas materiais ou imateriais e do processo, isto é, os técnicos (métodos, sistemas técnicos de back office ou de front office) mobilizados para produzir as características de serviços; iii) [C] e [C'] referem-se às competências respectivas do prestador e do cliente cuja articulação [C] [C'] simboliza o que é denominado de interface da prestação.

Nos itens, a seguir, serão apresentados os resultados correspondentes a cada um dos vetores citados anteriormente.

4.3.1. Serviços de TIC - quanto a características de serviço, o seu valor de uso

De acordo com Gallouj (2007), um dos vetores a ser considerado para analisar a inovação de serviços é aquele que trata das características finais de serviços, os valores de uso, as utilidades fornecidas aos usuários e cliente. $O$ Quadro 12 apresenta as principais características identificadas nos serviços de TIC.

\begin{tabular}{|c|c|c|c|c|c|c|c|c|c|c|c|c|c|}
\hline \multirow[b]{2}{*}{$\begin{array}{l}\text { Características finais do serviço } \\
\qquad[\mathrm{Y}]\end{array}$} & \multicolumn{9}{|c|}{ Serviços Transacionais } & \multicolumn{4}{|c|}{$\begin{array}{l}\text { Serviços de apoio } \\
\text { à decisão }\end{array}$} \\
\hline & 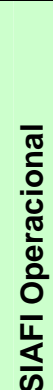 & 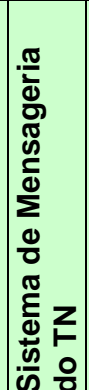 & 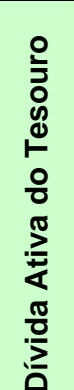 & 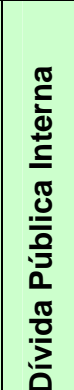 & 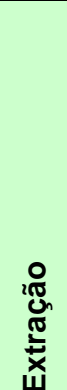 & 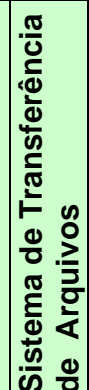 & 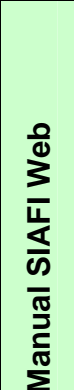 & $\begin{array}{l}\overline{\frac{\pi}{5}} \\
\text { ๘ } \\
\frac{\pi}{0} \\
\frac{\pi}{0}\end{array}$ & 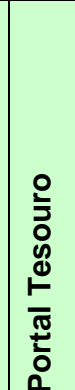 & 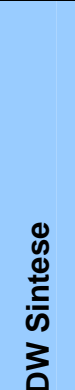 & 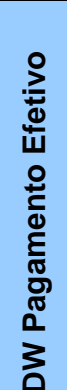 & $\begin{array}{l}\text { ग } \\
\text { @ } \\
\text { בे }\end{array}$ & 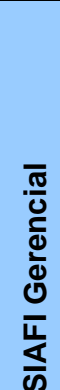 \\
\hline $\begin{array}{l}\text { Contabilidade pública como fonte } \\
\text { segura e tempestiva de informações } \\
\text { gerenciais destinadas a todos os } \\
\text { níveis da Administração Pública } \\
\text { Federal. }\end{array}$ & $\mathbf{x}$ & & & & & & & & & $\mathbf{x}$ & $\mathbf{x}$ & $\mathbf{x}$ & $\mathbf{x}$ \\
\hline
\end{tabular}




\begin{tabular}{|c|c|c|c|c|c|c|c|c|c|c|c|c|c|}
\hline \multirow[b]{2}{*}{$\begin{array}{l}\text { Características finais do serviço } \\
{[\mathrm{Y}]}\end{array}$} & \multicolumn{9}{|c|}{ Serviços Transacionais } & \multicolumn{4}{|c|}{$\begin{array}{l}\text { Serviços de apoio } \\
\text { à decisão }\end{array}$} \\
\hline & 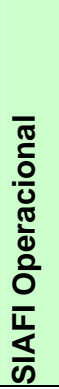 & 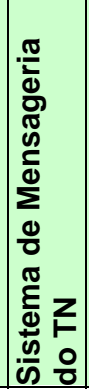 & 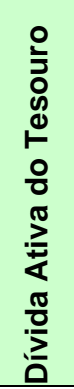 & 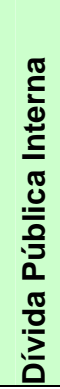 & 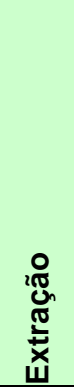 & 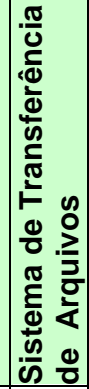 & 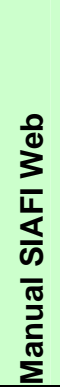 & $\begin{array}{l}\frac{\bar{L}}{\alpha} \\
\text { क } \\
\frac{\pi}{0} \\
\frac{\pi}{0}\end{array}$ & 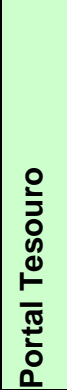 & 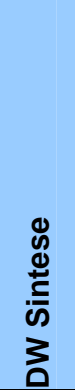 & 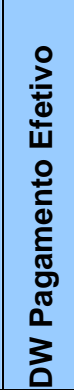 & $\begin{array}{l}\text { D } \\
\text { m } \\
3 \\
\vdots\end{array}$ & 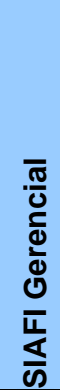 \\
\hline $\begin{array}{l}\text { Fornecimento de meios para agilizar } \\
\text { a programação financeira. }\end{array}$ & $\mathbf{x}$ & $\mathbf{x}$ & & & & & & & & & & & \\
\hline $\begin{array}{l}\text { Otimização da utilização dos } \\
\text { recursos do Tesouro Nacional, } \\
\text { através da unificação dos recursos } \\
\text { de caixa do Governo Federal. }\end{array}$ & $\mathbf{x}$ & $\mathbf{x}$ & & & & & & & & & & & \\
\hline $\begin{array}{l}\text { Mecanismos adequados ao controle } \\
\text { diário da execução orçamentária, } \\
\text { financeira e patrimonial aos órgãos } \\
\text { da Administração Pública }\end{array}$ & $\mathbf{x}$ & $\mathbf{x}$ & & & & & & & & & & & \\
\hline $\begin{array}{l}\text { Registro contábil dos balancetes dos } \\
\text { estados e municípios e de suas } \\
\text { supervisionadas }\end{array}$ & $\mathbf{x}$ & & & & & & & & & & & & \\
\hline $\begin{array}{l}\text { Controle da dívida interna e externa, } \\
\text { bem como o das transferências } \\
\text { negociadas }\end{array}$ & $\mathbf{x}$ & & $\mathbf{x}$ & $\mathbf{X}$ & & & & & & & & & \\
\hline $\begin{array}{l}\text { Integração e compatibilização das } \\
\text { informações no âmbito do Governo } \\
\text { Federal }\end{array}$ & $\mathbf{x}$ & $\mathbf{x}$ & $\mathbf{x}$ & $\mathbf{x}$ & & & & & & $\mathbf{x}$ & $\mathbf{x}$ & $\mathbf{x}$ & $\mathbf{x}$ \\
\hline $\begin{array}{l}\text { Acompanhamento e a avaliação do } \\
\text { uso dos recursos públicos }\end{array}$ & $\mathbf{x}$ & $\mathbf{x}$ & $\mathbf{x}$ & $\mathbf{x}$ & & & & $\mathbf{x}$ & $\mathbf{x}$ & $\mathbf{x}$ & $\mathbf{x}$ & $\mathbf{x}$ & $\mathbf{x}$ \\
\hline $\begin{array}{l}\text { Transparência e publicidade das } \\
\text { contas públicas }\end{array}$ & $\mathbf{x}$ & $\mathbf{x}$ & $\mathbf{x}$ & $\mathbf{x}$ & & & & $\mathbf{x}$ & $\mathbf{x}$ & $\mathbf{x}$ & & $\mathbf{x}$ & $\mathbf{x}$ \\
\hline $\begin{array}{l}\text { Funcionalidades que geram } \\
\text { produtividade e qualidade na } \\
\text { execução das atividades técnicas e } \\
\text { operacionais. }\end{array}$ & $\mathbf{x}$ & $\mathbf{x}$ & $\mathbf{x}$ & $\mathbf{x}$ & & & & & & & & & \\
\hline $\begin{array}{l}\text { Funcionalidades que geram } \\
\text { produtividade e qualidade na } \\
\text { execução das atividades gerenciais }\end{array}$ & & & & & & & & & & $\mathbf{x}$ & $\mathbf{x}$ & $\mathbf{x}$ & $\mathbf{x}$ \\
\hline $\begin{array}{l}\text { Funcionalidades que geram } \\
\text { eficiência no controle das contas } \\
\text { públicas }\end{array}$ & $\mathbf{x}$ & $\mathbf{x}$ & $\mathbf{x}$ & $\mathbf{x}$ & & & & & & $\mathbf{x}$ & $\mathbf{x}$ & $\mathbf{x}$ & $\mathbf{x}$ \\
\hline $\begin{array}{l}\text { Funcionalidades que geram } \\
\text { eficiência na auditoria }\end{array}$ & $\mathbf{x}$ & $\mathbf{x}$ & & & & & & & & $\mathbf{x}$ & $\mathbf{x}$ & $\mathbf{x}$ & $\mathbf{x}$ \\
\hline $\begin{array}{l}\text { Padronização dos métodos e das } \\
\text { rotinas de trabalho de gestão dos } \\
\text { recursos públicos }\end{array}$ & $\mathbf{x}$ & $\mathbf{x}$ & $\mathbf{x}$ & $\mathbf{x}$ & & & & & & & & & \\
\hline $\begin{array}{l}\text { Não repúdio dos dados registrados } \\
\text { - confiabilidade }\end{array}$ & $\mathbf{x}$ & $\mathbf{x}$ & $\mathbf{x}$ & $\mathbf{x}$ & & & & & & & & & \\
\hline $\begin{array}{l}\text { Controle efetivo de acesso aos } \\
\text { dados e informações }\end{array}$ & $\mathbf{x}$ & $\mathbf{x}$ & $\mathbf{x}$ & $\mathbf{x}$ & & & & & & $\mathbf{x}$ & $\mathbf{x}$ & $\mathbf{x}$ & $\mathbf{x}$ \\
\hline $\begin{array}{l}\text { Conformidade dos serviços às leis e } \\
\text { normas vigentes. }\end{array}$ & $\mathbf{x}$ & $\mathbf{x}$ & $\mathbf{x}$ & $\mathbf{x}$ & & & $\mathbf{x}$ & $\mathbf{x}$ & $\mathbf{x}$ & $\mathbf{x}$ & $\mathbf{x}$ & $\mathbf{x}$ & $\mathbf{x}$ \\
\hline $\begin{array}{l}\text { Facilidades para tratamento e } \\
\text { geração de informações gerenciais } \\
\text { e de prestações de contas pelos } \\
\text { próprios gestores. }\end{array}$ & & & & & & & & & & $\mathbf{x}$ & $\mathbf{x}$ & $\mathbf{x}$ & $\mathbf{x}$ \\
\hline
\end{tabular}




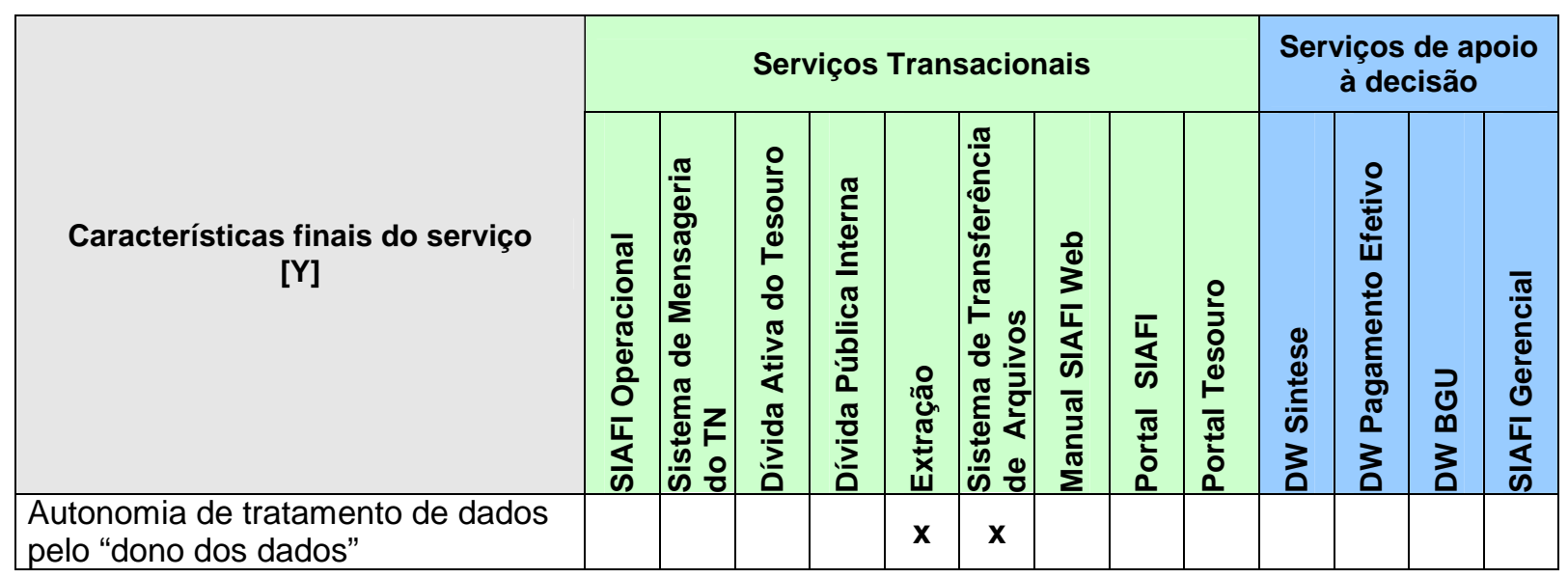

Quadro 12 - Principais características finais dos serviços de TIC Fonte: Elaboração da autora.

Conforme destacados no Quadro 12, as características atribuídas aos serviços transacionais e de apoio à decisão, com uma maior freqüência, foram relativas à sua capacidade de contribuir na: integração e compatibilização das informações no âmbito do Governo Federal; acompanhamento e a avaliação do uso dos recursos públicos; transparência e publicidade das contas públicas; e controle efetivo de acesso aos dados e informações e conformidade às leis e normas vigentes.

Em relação aos serviços transacionais, além das citadas anteriormente, destacam-se as características relativas à: padronização dos métodos e rotinas de trabalho de gestão dos recursos públicos e não repúdio dos dados registrados confiabilidade e produtividade e qualidade na execução das atividades técnicas e operacionais. Os serviços transacionais, pela sua natureza, estão voltados à eficiência e efetividade das atividades técnicas e operacionais.

Ainda, em relação aos serviços transacionais, dentre os serviços relacionados no Quadro 12, destaca-se o SIAFI Operacional, com os seus vinte e dois anos de existência, é o sistema mais antigo em produção e apresenta o maior número de características e valor de uso para os usuários e cliente, através do seu conjunto de serviços que somam, aproximadamente hum mil funcionalidades ofertadas.

Em relação aos serviços de apoio à decisão, além das características citadas, anteriormente, destacam-se as relativas: à contabilidade pública como fonte segura e tempestiva de informações gerenciais destinadas a todos os níveis da Administração Pública Federal; às funcionalidades que geram produtividade e qualidade na execução das atividades gerenciais; às facilidades para tratamento e 
geração de informações gerenciais e de prestações de contas pelos próprios gestores; e às funcionalidades que geram eficiência na auditoria. A primeira característica citada refere-se ao principal paradigma da implementação do SIAFI Operacional e, sendo este principal fonte de dados dos sistemas de apoio à decisão. Como conseqüência, estes herdam fortemente esta característica. Os serviços de apoio à decisão, pela sua natureza, estão voltados à eficiência e na eficácia da gestão das contas públicas.

É interessante notar que todas as características apresentadas no Quadro 12 estão relacionadas, direta ou indiretamente, aos atributos de práticas inovadoras de gestão pública mapeados pelo Klering e Andrade (2006), analisados na seção 4.4 .

\subsubsection{Serviços de $T I C$ - quanto a características técnicas}

$\mathrm{Na}$ subseção anterior foram apresentadas as características de uso dos serviços. Conforme Gallouj (2007), outros dois vetores devem ser considerados para analisar a inovação de serviços. Nesta subseção é tratado o vetor de características técnicas materiais ou imateriais e do processo (métodos, sistemas técnicos de back office ou de front office) mobilizados para produzir as especificidades dos serviços.

As principais características técnicas dos serviços identificadas nesta pesquisa estão relacionadas no Quadro 13. 


\begin{tabular}{|c|c|c|c|c|c|c|c|c|c|c|c|c|c|}
\hline \multirow[b]{2}{*}{ Características Técnicas de Serviços } & \multicolumn{9}{|c|}{ Serviços Transacionais } & \multicolumn{4}{|c|}{$\begin{array}{l}\text { Serviços de } \\
\text { apoio à decisão }\end{array}$} \\
\hline & $\begin{array}{l}\bar{\sigma} \\
\frac{0}{0} \\
\frac{0}{0} \\
\frac{\pi}{0} \\
\frac{0}{0} \\
\frac{\pi}{4} \\
\frac{1}{\omega}\end{array}$ & 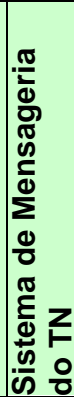 & 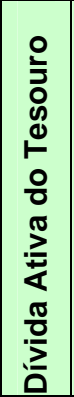 & 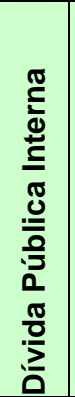 & 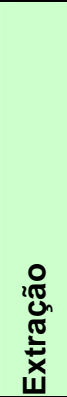 & 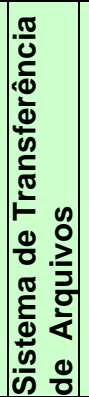 & $\frac{\frac{0}{00}}{\frac{3}{0}}$ & $\begin{array}{l}\frac{\pi}{4} \\
\text { क } \\
\text { कू } \\
\frac{1}{0}\end{array}$ & 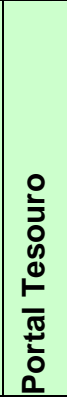 & 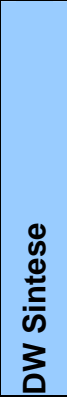 & 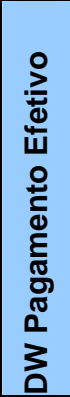 & $\begin{array}{l}\text { गे } \\
\text { @ } \\
3 \\
\text { za }\end{array}$ & 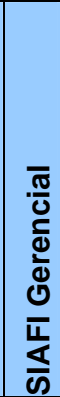 \\
\hline \multicolumn{14}{|c|}{ Arquitetura e Tecnologia } \\
\hline $\begin{array}{l}\text { Adoção de tecnologias de ponta ou } \\
\text { novas }^{13} \text {, quando da criação do serviço. }\end{array}$ & $\mathbf{x}$ & $\mathbf{x}$ & $\mathbf{x}$ & $x$ & $\mathbf{x}$ & $\mathbf{x}$ & $\mathbf{x}$ & $\mathbf{x}$ & $\mathbf{x}$ & $x$ & $\mathbf{x}$ & $\mathbf{x}$ & $\mathbf{x}$ \\
\hline $\begin{array}{l}\text { Adoção de HW com características } \\
\text { diferenciadas. }\end{array}$ & $\mathbf{x}$ & $\mathbf{x}$ & & & & & & & & & & & \\
\hline $\begin{array}{l}\text { Arquitetura de serviço com foco na } \\
\text { segurança, robustez e integridade. }\end{array}$ & $\mathbf{x}$ & $\mathbf{x}$ & $\mathbf{x}$ & $\mathbf{x}$ & $\mathbf{x}$ & $\mathbf{x}$ & $\mathbf{x}$ & $\mathbf{x}$ & $\mathbf{x}$ & $\mathbf{x}$ & $\mathbf{x}$ & $\mathbf{x}$ & $\mathbf{x}$ \\
\hline $\begin{array}{l}\text { Arquitetura Cliente-Servidor, considerada } \\
\text { de ponta quando da criação do serviço. }\end{array}$ & & & $\mathbf{x}$ & $x$ & & & & & & & & & $\mathbf{x}$ \\
\hline $\begin{array}{l}\text { Arquitetura de serviço para tratamento de } \\
\text { informação de apoio à decisão }\end{array}$ & & & & & & & & & & $\mathbf{x}$ & $\mathbf{x}$ & $\mathbf{x}$ & $\mathbf{x}$ \\
\hline Arquitetura escalável & $\mathbf{x}$ & $\mathbf{x}$ & $\mathbf{x}$ & $\mathbf{x}$ & & & & & & $\mathbf{x}$ & $\mathbf{x}$ & $\mathbf{x}$ & $\mathbf{x}$ \\
\hline Alta capilaridade & $\bar{x}$ & & & & & & & $\mathbf{x}$ & $\mathbf{x}$ & $\mathrm{x}$ & $\mathbf{x}$ & $x$ & $\mathbf{x}$ \\
\hline $\begin{array}{l}\text { Evolução dos serviços de impressão } \\
\text { (produtividade, portabilidade e economia) }\end{array}$ & $\mathbf{x}$ & & & & & & & & & & & & \\
\hline Alta disponibilidade & $\mathbf{x}$ & $\mathbf{x}$ & $\mathbf{x}$ & $\mathbf{x}$ & & & & & & & & & \\
\hline $\begin{array}{l}\text { Uso de tecnologia ETL para extração, } \\
\text { tratamento e carga dos dados (exemplo: } \\
\text { Power Center) }\end{array}$ & & & & & $\mathbf{x}$ & & & & & $\mathbf{x}$ & & & \\
\hline $\begin{array}{l}\text { Uso de tecnologia especializada para } \\
\text { transferência dos dados (FTP, Qware, } \\
\text { Power Center etc) }\end{array}$ & & & & & $\mathbf{x}$ & $\mathbf{x}$ & & & & $\mathbf{x}$ & $\mathbf{x}$ & $\mathbf{x}$ & $\mathbf{x}$ \\
\hline $\begin{array}{l}\text { Integração de tecnologias para oferecer } \\
\text { serviços adicionais para o usuário } \\
\text { (exemplo: integração do Forms Oracle } \\
\text { com MS Office, etc) }\end{array}$ & $\mathbf{x}$ & $\mathbf{x}$ & & & & & & & & & & & $\mathbf{x}$ \\
\hline $\begin{array}{l}\text { Uso de tecnologia livre (Java, Apache, } \\
\text { Zope/Plone, Phyton, etc) }\end{array}$ & & $\mathbf{x}$ & & & & & $\mathbf{x}$ & $\mathbf{x}$ & $\mathbf{x}$ & & & & \\
\hline Alta tolerância a falhas & & $\mathbf{x}$ & & & & & & & & & & & \\
\hline $\begin{array}{l}\text { Ambiente de contingência externa, com } \\
\text { gerenciamento remoto, e redundâncias de } \\
\text { infra-estrutura }\end{array}$ & & $\mathbf{x}$ & & & & & & & & & & & \\
\hline Replicação de dados & & $\mathbf{x}$ & & & & & & & & & & & \\
\hline Monitoração do serviço & $\mathbf{x}$ & $\mathbf{x}$ & $\mathbf{x}$ & $\mathbf{x}$ & $\mathbf{x}$ & $\mathbf{x}$ & $\mathbf{x}$ & $\mathbf{x}$ & $\mathbf{x}$ & $\mathbf{x}$ & $\mathbf{x}$ & $\mathbf{x}$ & $\mathbf{x}$ \\
\hline $\begin{array}{l}\text { Gerenciamento da infra-estrutura com } \\
\text { foco nos itens de configuração }\end{array}$ & $\mathbf{x}$ & $\mathbf{x}$ & $\mathbf{x}$ & $x$ & $\mathbf{x}$ & $\mathbf{x}$ & $\mathbf{x}$ & $\mathbf{x}$ & $x$ & $\mathbf{x}$ & $\mathbf{x}$ & $\mathbf{x}$ & $\mathbf{x}$ \\
\hline $\begin{array}{l}\text { Gerenciamento da infra-estrutura com } \\
\text { foco no serviço }\end{array}$ & & $\mathbf{x}$ & & & & & & & & & & & \\
\hline \multicolumn{14}{|c|}{ Tecnologia de Interação com usuários } \\
\hline Existência de processos batch críticos & $\mathbf{x}$ & & & & $\mathbf{x}$ & $\mathbf{x}$ & & & & $\mathbf{x}$ & $\mathbf{x}$ & $\mathbf{x}$ & $\mathbf{x}$ \\
\hline $\begin{array}{l}\text { Interação on-line, orientada a caracter, } \\
\text { novidade a época da criação }\end{array}$ & $\mathbf{x}$ & & & & & & & & & & & & \\
\hline
\end{tabular}

${ }^{13}$ Tecnologias que ainda não tinha sido internalizadas em serviços pela equipe. 


\begin{tabular}{|l|l|l|l|l|l|l|l|l|l|l|l|l|}
\hline \multirow{2}{*}{} & \multicolumn{9}{|c|}{ Serviços Transacionais } & \multicolumn{3}{c|}{ Serviços de } \\
apoio à decisão
\end{tabular}

\section{Quadro 13 - Características técnicas dos serviços}

Fonte: Elaboração da autora.

As características técnicas presentes em todos os serviços são: i) adoção de tecnologia de ponta ou novas quando da sua criação. Sendo todos serviços implementados por uma empresa especializada em TIC, é natural que esta característica seja fortemente manifestada, principalmente na criação do serviço, fortalecendo as práticas de inovação. Na pesquisa foi identificada que a arquitetura tecnológica dos serviços passam por algumas evoluções, porém, pelo porte dos sistemas, a sua estrutura básica original não sofrem grandes alterações arquiteturais, na sua essência; ii) monitoração do serviço. Todos os serviços são monitorados pelos especialistas de infra-estrutura de acordo com procedimentos

\footnotetext{
${ }^{14} \mathrm{O}$ uso do PGPS acontece, a partir da sua implantação na empresa em 2005, no desenvolvimento de novos sistemas (por exemplo, SOTN e serviços DW) e nos projetos de evolução ou de inclusão de novos serviços aos sistemas existentes (por exemplo, SIAFI Operacional e SIAFI Gerencial).
} 
formalmente estabelecidos; iii) gerenciamento da infra-estrutura com foco nos itens de configuração. Os itens de configuração (hardware, software e aplicação) são gerenciados pelas respectivas unidades de infra-estrutura de acordo com procedimentos formalmente estabelecidos; iv) arquitetura de serviço com foco na segurança, robustez e integridade. Todos os serviços possuem arquitetura capaz de assegurar estas características, de acordo com a respectiva necessidade.

As demais características técnicas atribuídas aos serviços transacionais e de apoio à decisão, com uma maior freqüência são: i) arquitetura escalável que permite o crescimento da solução de forma gradativa, em conformidade com o crescimento vegetativo natural do serviço; ii) uso do PSDS que estabelece um processo de desenvolvimento de sistemas de informação (software) padronizado do SERPRO, com as melhores práticas do mercado e da própria empresa, visando alcançar nível de maturidade, conforme estabelecido pelo Capability Maturity Model $(C M M)^{15}$ (SERPRO, 2009c); iii) uso do PSS que estabelece um processo padronizado de gerenciamento de requisitos de segurança dos serviços. O PSS segue normas e padronizações especificadas por diversos órgãos e instituições nacionais e internacionais, com foco na manutenção da chamada "pirâmide básica da segurança" - confidencialidade, integridade e disponibilidade (SERPRO, 2009e); iv) uso do PSGS que estabelece um processo de gerenciamento de serviços de TIC, baseado em um modelo para efetivar a gestão, identificação e inter-relacionamento das várias atividades envolvidas no aperfeiçoamento da estrutura para entregar, mensurar e aperfeiçoar o gerenciamento de serviços em Tecnologia da Informação e Comunicação (TIC) que foi desenvolvido tendo como base o modelo de referência Information Technology Infrastructure Library $(\mathrm{ITIL})^{16}$, agregando as práticas internas da empresa (SERPRO, 2009d).

Especificamente, em relação aos serviços transacionais, as seguintes características estão presentes na maioria dos serviços: i) uso de tecnologia de alta disponibilidade, em correspondência à criticidade da área orçamentária e financeira da Administração Pública Federal ii) uso de tecnologia livre alinhada à Estratégia Geral de Tecnologia da Informação (EGTI) de 2008 para a Administração Pública Federal (MINISTÉRIO DO PLANEJAMENTO, ORÇAMENTO E GESTÃO, 2008) e 
estabelecido no PGTI como um dos principais direcionamentos estratégicos e tecnológico do SERPRO: "Utilização de Software Livre como recurso estratégico para implementação do Governo Eletrônico (e-Gov)” (SERPRO, 2009f).

Especificamente, em relação aos serviços de apoio à decisão, as seguintes características destacam-se na sua maioria: i) arquitetura de serviço para tratamento de informação de apoio à decisão, com uso de tecnologia específica como o DW; ii) uso de tecnologia especializada para transferência dos dados para buscar dados das bases de origem; iii) existência de processos batch críticos, para tratamento dos dados para criar base de dados gerencias; iv) existência de dicionário de dados integrados ao serviço de help aos usuários, característica da tecnologia DW que facilitam o entendimento dos dados pelos usuários para apoiar no correto tratamento dos dados; v) geração de arquivo portável para permitir tratamento dos dados agregados a outros dados oriundos de outras fontes; v) uso do PSGP que estabelece um processo de gerenciamento de projetos padronizado do SERPRO, tendo como base as melhores práticas recomendadas pelo Project Management Body of Knowledge (PMBOK) - um guia com um conjunto de conhecimentos em gerenciamento de projetos e as práticas internas da empresa (SERPRO, 2009b). destaque desta característica nos serviços de apoio à decisão deve-se ao fato dos projetos terem sido implementados após a instituição do PSGP.

Os processos corporativos (PSDS, PGPS, PSS e PSGS) visam a eficiência e a efetividade na entrega de serviços em conformidade com os níveis acordados com o cliente e são fortemente aplicados, principalmente, em novos projetos de serviços de TIC.

\subsubsection{Competências do prestador de serviço de TIC e do cliente.}

Nas duas subseções anteriores foram analisadas as características de uso e as características técnicas dos serviços que representam, respectivamente, dois vetores do modelo único de representação de inovação do Gallouj (2007). Nesta

\footnotetext{
${ }^{15}$ CMM para software é um conjunto de processos desenvolvido pela SEI - Software Engineering Institute (www.sei.cmu.edu) em 1986 para melhorar o desenvolvimento de aplicações em organizações que trabalham com tecnologias de software. O processo é divido em 5 níveis de desenvolvimento: 1) Inicial, 2) repetível, 3) definido, 4) gerenciado com métricas e 5) otimizado.

${ }^{16}$ ITIL aglutina os melhores processos e práticas para ancorar a gestão de serviços de TIC.
} 
subseção, apresenta-se a análise das inovações sob a ótica do terceiro e último vetor que trata das competências respectivas do prestador e do cliente, cuja articulação simboliza a interface da prestação de serviço.

As principais competências mobilizadas para a implementação e operacionalização dos serviços estão identificadas no Quadro 14.

\begin{tabular}{|c|c|c|c|c|c|c|c|c|c|c|c|c|c|}
\hline \multirow[b]{2}{*}{ Competências do prestador e do cliente } & \multicolumn{9}{|c|}{ Serviços Transacionais } & \multicolumn{4}{|c|}{$\begin{array}{l}\text { Serviços de apoio } \\
\text { à decisão }\end{array}$} \\
\hline & 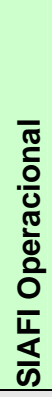 & 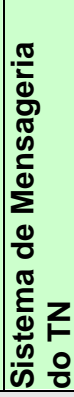 & 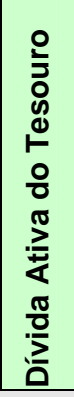 & 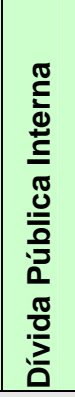 & 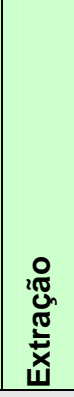 & 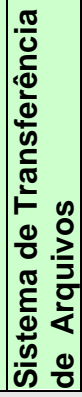 & 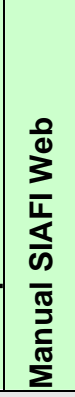 & $\begin{array}{l}\overline{\frac{\pi}{5}} \\
\text { क } \\
\bar{\sigma} \\
\frac{\pi}{0} \\
0\end{array}$ & 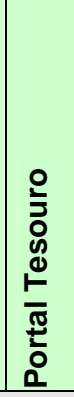 & 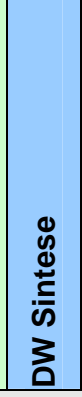 & 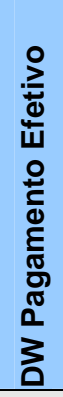 & $\begin{array}{l}\text { D } \\
\text { m } \\
3 \\
0\end{array}$ & 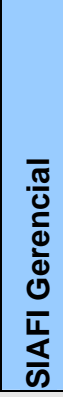 \\
\hline \multicolumn{14}{|c|}{ Do Prestador de Serviços } \\
\hline $\begin{array}{l}\text { Alta especialização em tecnologias } \\
\text { aplicadas no desenvolvimento, } \\
\text { manutenção e produção do serviço }\end{array}$ & $\mathbf{x}$ & $\mathbf{x}$ & $\mathbf{x}$ & $\mathbf{x}$ & $\mathbf{x}$ & $\mathbf{x}$ & $\mathbf{x}$ & $\mathbf{x}$ & $\mathbf{x}$ & $\mathbf{x}$ & $\mathbf{x}$ & $\mathbf{x}$ & $\mathbf{x}$ \\
\hline $\begin{array}{l}\text { Conhecimento da arquitetura } \\
\text { tecnológica do serviço }\end{array}$ & $\mathbf{x}$ & $\mathbf{x}$ & $\mathbf{x}$ & $\mathbf{x}$ & $\mathbf{x}$ & $\mathbf{x}$ & $\mathbf{x}$ & $\mathbf{x}$ & $\mathbf{x}$ & $\mathbf{x}$ & $\mathbf{x}$ & $\mathbf{x}$ & $\mathbf{x}$ \\
\hline $\begin{array}{l}\text { Conhecimento de negócio orçamento e } \\
\text { finanças }\end{array}$ & $\mathbf{x}$ & $\mathbf{x}$ & $\mathbf{x}$ & $\mathbf{x}$ & & & & & & $\mathbf{x}$ & $\mathbf{x}$ & $\mathbf{x}$ & $\mathbf{x}$ \\
\hline $\begin{array}{l}\text { Capacidade de entender a necessidade } \\
\text { como um todo (visão sistêmica) }\end{array}$ & $\mathbf{x}$ & $\mathbf{x}$ & $\mathbf{x}$ & $\mathbf{x}$ & $\mathbf{x}$ & $\mathbf{x}$ & $\mathbf{x}$ & $\mathbf{x}$ & $\mathbf{x}$ & $\mathbf{x}$ & $\mathbf{x}$ & $\mathbf{x}$ & $\mathbf{x}$ \\
\hline $\begin{array}{l}\text { Conhecimento de sistemas } \\
\text { estruturantes do Governo Federal, } \\
\text { visando integração }\end{array}$ & $\mathbf{x}$ & $\mathbf{x}$ & & & & & & & & $\mathbf{x}$ & & & \\
\hline $\begin{array}{l}\text { Conhecimento da estrutura e dos } \\
\text { conceitos dos dados armazenados } \\
\text { (visão conceitual, lógica e física) }\end{array}$ & $\mathbf{x}$ & $\mathbf{x}$ & $\mathbf{x}$ & $\mathbf{x}$ & $\mathbf{x}$ & $\mathbf{x}$ & $\mathbf{x}$ & $\mathbf{x}$ & $\mathbf{x}$ & $\mathbf{x}$ & $\mathbf{x}$ & $\mathbf{x}$ & $\mathbf{x}$ \\
\hline $\begin{array}{l}\text { Capacidade de propor e implementar } \\
\text { soluções adequadas do ponto de vista } \\
\text { tecnológico e orçamentário }\end{array}$ & $\mathbf{x}$ & $\mathbf{x}$ & $\mathbf{x}$ & $\mathbf{x}$ & $\mathbf{x}$ & $\mathbf{x}$ & $\mathbf{x}$ & $\mathbf{x}$ & $\mathbf{x}$ & $\mathbf{x}$ & $\mathbf{x}$ & $\mathbf{x}$ & $\mathbf{x}$ \\
\hline $\begin{array}{l}\text { Utilização dos processos corporativos, } \\
\text { com "as melhores práticas"17 em } \\
\text { desenvolvimento de software, } \\
\text { gerenciamento de projetos, } \\
\text { gerenciamento de serviços e gestão de } \\
\text { segurança. }\end{array}$ & & $\mathbf{x}$ & & & & $\mathbf{x}$ & & & & $\mathbf{x}$ & $\mathbf{x}$ & $\mathbf{x}$ & \\
\hline $\begin{array}{l}\text { Capacidade de trabalhar em projetos } \\
\text { de grande envergadura com equipes } \\
\text { multidisciplinares. }\end{array}$ & $\mathbf{x}$ & $\mathbf{x}$ & & & & & & & & $\mathbf{x}$ & & & \\
\hline $\begin{array}{l}\text { Capacidade de gerenciamento remoto } \\
\text { de projetos e serviços }\end{array}$ & & $\mathbf{x}$ & & & & & & & & & & & \\
\hline $\begin{array}{l}\text { Equipe com alta capacidade de } \\
\text { aprendizado para o novo }\end{array}$ & $\mathbf{x}$ & $\mathbf{x}$ & $\mathbf{x}$ & $\mathbf{x}$ & $\mathbf{x}$ & $\mathbf{x}$ & $\mathbf{x}$ & $\mathbf{x}$ & & $\mathbf{x}$ & & $\mathbf{x}$ & $\mathbf{x}$ \\
\hline
\end{tabular}

17 Melhores práticas baseadas nos modelos consagrados no mercado e nas práticas internas de resultados comprovados. 


\begin{tabular}{|c|c|c|c|c|c|c|c|c|c|c|c|c|c|}
\hline \multirow[b]{2}{*}{ Competências do prestador e do cliente } & \multicolumn{9}{|c|}{ Serviços Transacionais } & \multicolumn{4}{|c|}{$\begin{array}{l}\text { Serviços de apoio } \\
\text { à decisão }\end{array}$} \\
\hline & 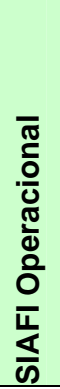 & 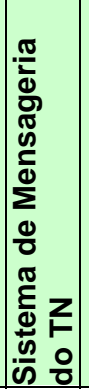 & 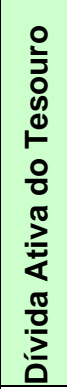 & 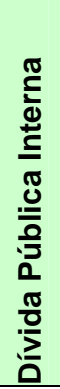 & 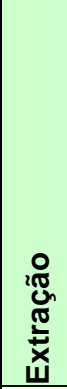 & 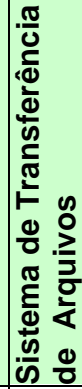 & 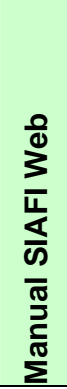 & 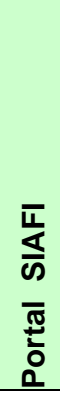 & 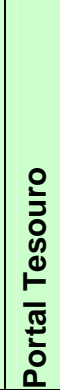 & 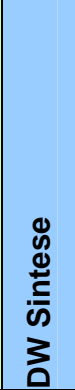 & 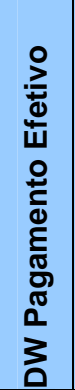 & $\begin{array}{l}J \\
\text { D } \\
0 \\
3 \\
0\end{array}$ & 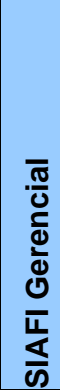 \\
\hline $\begin{array}{l}\text { Tratamento de incidentes e problemas } \\
\text { de forma pró-ativa na produção dos } \\
\text { serviços }\end{array}$ & $\mathbf{x}$ & $\mathbf{x}$ & & & & & & & & & & & $\mathbf{x}$ \\
\hline Monitoração de serviços em real-time & & $\mathbf{x}$ & & & & & & & & & & & \\
\hline \multicolumn{14}{|c|}{ Do Cliente } \\
\hline $\begin{array}{l}\text { Alta especialização no segmento de do } \\
\text { negócio orçamento e finanças }\end{array}$ & $\mathbf{x}$ & $\mathbf{x}$ & $\mathbf{x}$ & $\mathbf{x}$ & & & & $\mathbf{x}$ & $\mathbf{x}$ & $\mathbf{x}$ & $\mathbf{x}$ & $\mathbf{x}$ & $\mathbf{x}$ \\
\hline Compreensão das suas necessidades & $\mathbf{x}$ & $\mathbf{x}$ & $\mathbf{x}$ & $\mathbf{x}$ & $\mathbf{x}$ & $\mathbf{x}$ & $\mathbf{x}$ & $\mathbf{x}$ & $\mathbf{x}$ & $\mathbf{x}$ & $\mathbf{x}$ & $\mathbf{x}$ & $\mathbf{x}$ \\
\hline $\begin{array}{l}\text { Capacidade de entendimento dos } \\
\text { modelos lógicos }\end{array}$ & $\mathbf{x}$ & $\mathbf{x}$ & $\mathbf{x}$ & $\mathbf{x}$ & & & & & & $\mathbf{x}$ & $\mathbf{x}$ & $\mathbf{x}$ & $\mathbf{x}$ \\
\hline $\begin{array}{l}\text { Capacidade de definir os requisitos de } \\
\text { negócio }\end{array}$ & $\mathbf{x}$ & $\mathbf{x}$ & $\mathbf{x}$ & $\mathbf{x}$ & & & $\mathbf{x}$ & $\mathbf{x}$ & $\mathbf{x}$ & $\mathbf{x}$ & $\mathbf{x}$ & $\mathbf{x}$ & $\mathbf{x}$ \\
\hline $\begin{array}{l}\text { Conhecimento das tecnologias de } \\
\text { TIC }^{18}\end{array}$ & & $\mathbf{x}$ & & & & & & $\mathbf{x}$ & $\mathbf{x}$ & & & & \\
\hline $\begin{array}{l}\text { Conhecimento para utilização de } \\
\text { ferramenta DW pelos gestores }\end{array}$ & & & & & & & & & & $\mathbf{x}$ & $\mathbf{x}$ & $\mathbf{x}$ & $\mathbf{x}$ \\
\hline
\end{tabular}

Quadro 14 - Competências mobilizadas para implementação dos serviços Fonte: Elaboração da autora.

Conforme apresentado no Quadro 14, entre as competências mobilizadas pelo prestador de serviços destacam-se: i) a alta especialização em tecnologias aplicadas no desenvolvimento, manutenção e produção do serviço. Porém, este nível de especialização é representado por um grupo pequeno de especialistas; ii) o conhecimento da arquitetura tecnológica do serviço; iii) o conhecimento de negócio sobre orçamento e finanças obtido pelo acúmulo de conhecimento pelos analistas de sistemas e gestores de negócio, ao longo do tempo de atuação nos serviços, e pela formalização dos requisitos dos sistemas, conforme estabelecido pelo PSDS; iv) a capacidade de entender a necessidade como um todo (visão sistêmica), característica presente na maioria dos analistas de sistemas e gestores de negócio alocados; v) o conhecimento da estrutura e dos conceitos dos dados armazenados (visão conceitual, lógica e física) é formalizado conforme PSDS; vi) a capacidade de propor e implementar soluções adequadas do ponto de vista tecnológico e 
orçamentário; vii) equipe com alta capacidade de aprendizado para o novo.

Em síntese, as competências do prestador destacadas estão relacionadas, basicamente, ao conhecimento das tecnologias aplicadas (hardware, software, processos, técnicas etc) e dos segmentos de negócio informatizados pelos sistemas de informações.

A STN, o principal cliente da SUNAF, possui um papel fundamental na gestão de finanças públicas no país. Praticamente todos os serviços pesquisados têm a STN como cliente, com exceção do Sintese que é do TCU. Assim, para introduzir a análise de competências do cliente, apresenta-se o decreto de criação da STN (STN, 2009),

\begin{abstract}
"a Secretaria do Tesouro Nacional foi criada, em 10 de março de 1986, conforme Decreto no 92.452, unindo a antiga Comissão de Programação Financeira e a Secretaria de Controle Interno do Ministério da Fazenda. Constitui-se órgão central do Sistema de Administração Financeira Federal e do Sistema de Contabilidade Federal. Sua criação foi um passo significativo no fortalecimento das Finanças Públicas no Brasil"
\end{abstract}

Dentre as competências do cliente destacam-se no Quadro 14: i) alta especialização no segmento do negócio orçamento e finanças; ii) compreensão das suas necessidades para traduzir em requisitos do sistema de informação; iii) capacidade de entendimento dos modelos lógicos, facilitando a interação para definição correta dos requisitos do sistema de informação; iv) capacidade de definir os requisitos de negócio; v) conhecimento para utilização de ferramenta $D W$ pelos gestores adquirido a partir das interações com os analistas de sistemas e gestores de negócio, treinamento e utilização do sistema implementada com esta tecnologia. Apesar do conhecimento das tecnologias de TIC não estar identificado como competência mobilizada pelo cliente na maioria dos serviços pesquisados, há um aumento na quantidade de funcionários com esta especialização, tanto na STN como no TCU. Conforme entrevistado,

\footnotetext{
“... a STN possui no seu quadro analistas de sistemas que possuem alto grau de especialização e experiências no segmento de TIC, o que exige um maior conhecimento e especialização dos analistas de informáticas do SERPRO, nos diversos segmentos, que interagem, direta ou indiretamente com este cliente".
}

18 Este conhecimento está concentrado especificamente na Coordenação-Geral de Sistemas e Tecnologia de Informação COSIS/STN. O seu quadro de colaboradores conta com especialistas em TIC. Esta equipe intermedia a interação entre os especialistas de negócio e a equipe do SERPRO. 
Desde a sua criação, a STN tem o SERPRO como seu principal prestador de serviços de TIC e, durante esta parceria de 22 anos, juntos contabilizaram competências traduzidas em diversos serviços, hoje, imprescindíveis para o funcionamento da máquina pública e que impulsionam inovações em novos projetos, baseados em conhecimentos adquiridos e na aplicação de novas tecnologias, visando entrega de serviços de TIC que contribuem mais para eficiência e eficácia do gerenciamento das finanças públicas da Administração Pública Federal.

Em relação à análise do vetor das competências, vale destacar o aumento destas, tanto do prestador como do cliente, em cada interação realizada na implementação dos serviços, onde se registra um novo fenômeno: o prestador passa a conhecer cada vez mais o negócio e o cliente cada vez mais a tecnologia e a arquitetura da solução. Estes aspectos reforçam os conceitos dos SICs apresentados na subseção 2.1.2.

\subsubsection{Classificação das inovações em serviços de TIC}

Com base nas caracterizações realizadas sob os vetores de características, nesta subseção, os serviços foram classificados à luz dos modelos de inovação do Gallouj (2007), apresentados anteriormente, observando à dinâmica (positiva ou negativa) que surge nos vetores de características em suas várias formas, [C], [C'], [T], [Y] ou qualquer combinação destes vetores. O resultado da classificação está demonstrado no Quadro 15. 


\begin{tabular}{|c|c|c|c|c|c|c|c|c|c|c|c|c|c|}
\hline \multirow[b]{2}{*}{ Modelos de Inovação } & \multicolumn{9}{|c|}{ Serviços Transacionais } & \multicolumn{4}{|c|}{$\begin{array}{l}\text { Serviços de apoio } \\
\text { à decisão }\end{array}$} \\
\hline & 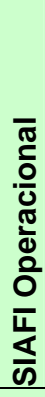 & 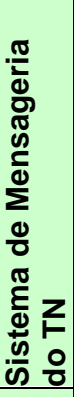 & 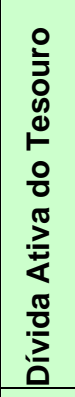 & 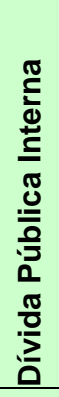 & 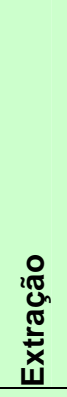 & 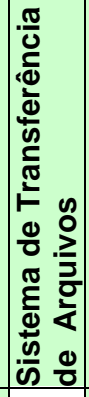 & 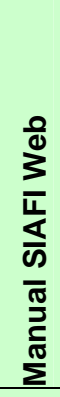 & 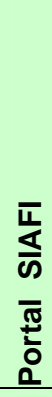 & 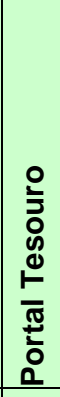 & 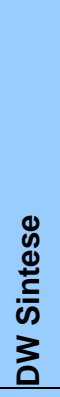 & 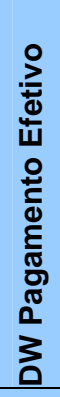 & $\begin{array}{l}\text { D } \\
\text { D } \\
\text { ż }\end{array}$ & 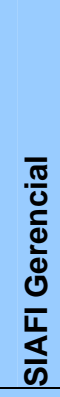 \\
\hline Inovação radical & $\mathbf{x}$ & $\mathbf{x}$ & $\mathbf{x}$ & $\mathbf{x}$ & $\mathbf{x}$ & & $\mathbf{x}$ & $\mathbf{x}$ & $\mathbf{x}$ & $\mathbf{x}$ & $\mathbf{x}$ & $\mathbf{x}$ & $\mathbf{x}$ \\
\hline Inovação pela melhoria & & & & & & $\mathbf{x}$ & & & & & & & \\
\hline \multicolumn{14}{|l|}{ Inovação incremental } \\
\hline \multicolumn{14}{|l|}{ Inovação ad hoc } \\
\hline \multicolumn{14}{|l|}{ Inovação pela recombinação } \\
\hline $\begin{array}{l}\text { Inovação pela formalização ou pela } \\
\text { objetivação }\end{array}$ & & & & & & & & & & & & & \\
\hline
\end{tabular}

Quadro 15 - Classificação dos serviços por modelo de inovação.

Fonte: Elaboração da autora.

Praticamente todos os serviços de TIC relacionados foram concebidos, desenvolvidos e produzidos norteados para: i) substituir os procedimentos realizados manualmente ou através de soluções "informatizados" em planilha ou software de manipulação simples, como Visual Basic, desenvolvidas pelos próprios funcionários da STN (caso dos sistemas que trata o segmento de dívidas); ii) atendimento a uma decisão de governo que determina a criação de um instrumento único de gestão orçamentária e financeira (caso do SIAFI Operacional); iii) nova oportunidade de gerar serviços de apoio à decisão (caso dos DWs); iv) oferecer transparência das ações e das contas públicas (caso dos portais); e v) fornecer autonomia de tratamento de dados pelos órgãos (caso da Extração).

Com exceção do Sistema de Transferência de Arquivos, as inovações em serviços dos serviços nota-se forte co-produção, fruto da parceria do cliente e do prestador, onde são concebidas e produzidas as características finais do serviço [Y]. Para tanto, há uma mobilização simultânea de características técnicas $[T]$, com destaque na utilização tecnologias, e das competências do cliente [C'] e do prestador de serviço [C]. Estes vetores foram caracterizados para cada serviço nos itens anteriores desta seção. Conforme mencionado, anteriormente, os serviços intensivos em conhecimento resultam em novas competências contabilizadas para 
as partes. Também há evidências de novas características técnicas agregadas aos serviços. Desta forma, pode-se afirmar que houve inovação radical nestes serviços, na sua primeira versão, conforme destacados no Quadro 15.

Porém, os serviços financeiros que implementam políticas públicas sofrem influências de mudanças tecnológicas, econômicas, políticas e legais. Estas mudanças não são poucas. Na pesquisa, foi identificada uma média de oitocentas demandas por ano, que representam necessidades de adequações, evoluções, novas funcionalidades e novos serviços, envolvendo ou não mudanças tecnológicas e adequações no ambiente produtivo (adequação de hardware e software, novos procedimentos de gerenciamento dos serviços etc). A maior parte destas, refere-se a serviços transacionais, muito sensíveis a mudanças de cunho legal e normativo e de procedimentos. No atendimento a essas demandas, envolvem novas interações entre o cliente e o prestador, que normalmente, resultam em inovação pela melhoria (aumento na qualidade das características) ou inovação incremental (adição ou eliminação de características). Pode-se afirmar que, com base nas demandas registradas, ao longo da existência destes serviços, todos os serviços citados agregaram inovações pela melhoria e incremental nas diversas versões do sistema. Estas inovações não foram explicitadas no Quadro 15, pois se destacou a versão de criação do serviço.

A inovação implementada pelo Sistema de Transferência de Arquivos (STA) foi classificada como inovação pela melhoria, pois é fruto do desejo de agregar qualidade de uso ao serviço denominado "Extrator" disponível no SIAFI Operacional. O serviço STA utiliza como back office o serviço "Extrator", com algumas funcionalidades complementares (por exemplo, maior volume de extração, combinação de dados de mais de uma tabela, agendamento etc) e características técnicas distintas como para acesso via web e com uso de software livre.

\subsection{Inovação em Serviços para Gestão Pública}

Nesta seção são apresentadas as diversas práticas inovadoras, presentes nos serviços de TIC, que agregam valor ao setor público, segundo os entrevistados. Como modelo, foi utilizada a abordagem baseada em características do Klering e Andrade (2006). Na elaboração do Quadro 16, adotou-se uma graduação na 
classificação das respostas obtidas, visto que as questões foram respondidas de forma livre e descritiva pelos entrevistados. Por exemplo, apesar de o SIAFI Operacional, implementar serviço de depósito em conta bancária para tratamento de saúde para um cidadão carente, serviços voltados para o cidadão, como este, são muito raros no catálogo de serviços da superintendência. Assim, no atributo "Simplificação da vida dos cidadãos", este serviço foi graduado com "B". Vale destacar que, neste serviço, o beneficiário não tem idéia que está utilizando o SIAFI.

Os serviços Extração e Sistema de Transferência de arquivos foram excluídos da análise do valor agregada a gestão pública. A exclusão justifica-se pelo fato destes serviços ter caráter de back office, não consistindo em gerar um valor agregado para apoiar diretamente a gestão pública. Estes serviços, simplesmente, permitem extrair dados do SIAFI para levar a um repositório específico definido pelo cliente para atender a necessidade específica de tratamento de dados por ele.

Legenda:
A - Alta aderência
M - Média aderência
$B$ - Baixa aderência
$X$ - Não se aplica

\begin{tabular}{|c|c|c|c|c|c|c|c|c|c|c|c|}
\hline Atributos de Inovação & $\begin{array}{l}\bar{\sigma} \\
\overline{0} \\
\frac{0}{0} \\
\frac{\pi}{0} \\
\frac{0}{0} \\
\overline{\frac{\pi}{5}} \\
\text { क }\end{array}$ & 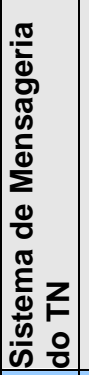 & 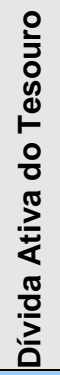 & 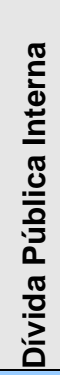 & 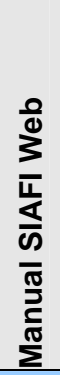 & 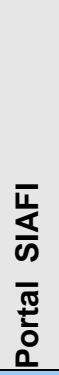 & 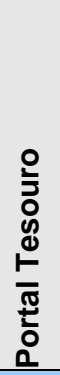 & 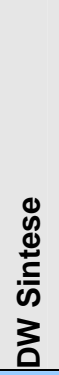 & 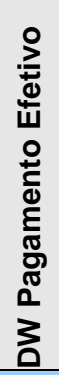 & $\begin{array}{l}\text { D } \\
\text { m } \\
\sum_{0}^{a}\end{array}$ & 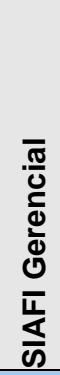 \\
\hline $\begin{array}{l}\text { Introdução de mudanças, qualitativas e } \\
\text { quantitativas, em relação às práticas } \\
\text { anteriores }\end{array}$ & A & A & A & A & A & A & A & A & A & A & A \\
\hline Credibilidade pública & A & A & A & A & A & A & A & A & A & A & A \\
\hline Accountability & A & A & A & A & A & A & A & A & A & A & A \\
\hline Compliance & A & A & A & A & A & A & A & A & A & A & A \\
\hline $\begin{array}{l}\text { Desenvolvimento de tecnologia e } \\
\text { responsabilidade na utilização de recursos e } \\
\text { oportunidades }\end{array}$ & A & A & A & A & A & A & A & A & A & A & A \\
\hline $\begin{array}{l}\text { Articulação entre governos de um mesmo } \\
\text { nível }\end{array}$ & A & A & A & A & $\mathrm{x}$ & A & A & A & A & A & A \\
\hline Articulação entre governos de diferentes níveis & M & M & M & M & $\mathrm{x}$ & M & A & B & $\mathrm{B}$ & $\mathrm{B}$ & B \\
\hline $\begin{array}{l}\text { Consolidação e ampliação do diálogo com a } \\
\text { sociedade civil }\end{array}$ & B & B & B & B & $\mathrm{x}$ & M & A & B & B & B & B \\
\hline Articulação com diferentes setores sociais & $\mathrm{B}$ & $B$ & $\mathrm{~B}$ & $\mathrm{~B}$ & $\mathrm{x}$ & $\mathrm{M}$ & A & B & $\mathrm{B}$ & B & B \\
\hline
\end{tabular}




\begin{tabular}{|c|c|c|c|c|c|c|c|c|c|c|c|}
\hline Atributos de Inovação & 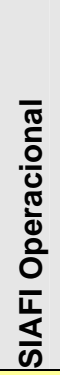 & 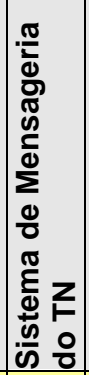 & 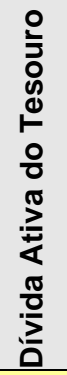 & 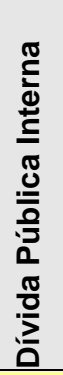 & 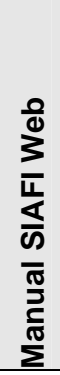 & $\begin{array}{l}\text { एँ } \\
\text { ๘ } \\
\bar{\pi} \\
\frac{\pi}{0} \\
0\end{array}$ & 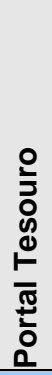 & 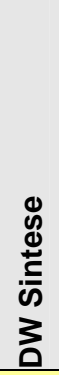 & 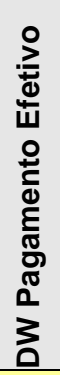 & $\begin{array}{l}\text { ग } \\
\text { m } \\
\text { ż }\end{array}$ & 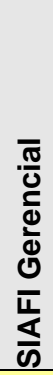 \\
\hline $\begin{array}{l}\text { Articulação com diferentes atores, grupos, } \\
\text { coletivos e segmentos sociais }\end{array}$ & $\mathrm{B}$ & B & $\mathrm{B}$ & $\mathrm{B}$ & $x$ & M & A & B & $\mathrm{B}$ & B & $\mathrm{B}$ \\
\hline Transferibilidade & $\mathrm{A}$ & A & A & A & $\mathrm{M}$ & A & $\mathrm{A}$ & A & $A$ & A & A \\
\hline Ampliação do número de beneficiários & A & $\mathrm{x}$ & $\mathrm{x}$ & $\mathrm{x}$ & $\mathrm{X}$ & $\mathrm{X}$ & $\mathrm{X}$ & A & A & A & A \\
\hline Permeabilidade ao público-alvo & $M$ & $A$ & A & A & $A$ & $\mathrm{M}$ & $\mathrm{M}$ & $A$ & $A$ & $A$ & $A$ \\
\hline Simplificação da vida dos cidadãos & $\mathrm{B}$ & $\mathrm{X}$ & $\mathrm{x}$ & $\mathrm{x}$ & B & $\mathrm{x}$ & $B$ & $\mathrm{x}$ & $x$ & $\mathrm{X}$ & $\mathrm{x}$ \\
\hline $\begin{array}{l}\text { Incorporação de tecnologias facilitadoras da } \\
\text { ação pública }\end{array}$ & $A$ & A & A & A & $M$ & $A$ & A & $A$ & A & $A$ & A \\
\hline $\begin{array}{l}\text { Fortalecimento do poder de gerenciamento } \\
\text { para governos }\end{array}$ & $A$ & A & $A$ & A & $x$ & $A$ & $A$ & A & $A$ & A & A \\
\hline Enfoque sistêmico & $A$ & $A$ & $A$ & $A$ & $x$ & $M$ & $\mathrm{M}$ & $A$ & $A$ & $A$ & $A$ \\
\hline
\end{tabular}

Quadro 16 - Práticas inovadoras de gestão pública em serviços de TIC.

Fonte: Elaboração da autora.

No Quadro 16, Destaca-se a concentração de área amarela, (aderência baixa) em relação ao poder dos serviços de contribuir para facilitar articulação com entidades e atores fora do Governo Federal. Este resultado pode ser natural para um órgão que tem somente vinte e três anos de existência, que ainda precisa de mais investimento nos próprios instrumentos de gestão, em nível federal, com um volume significativo de demandas em back log, não se consegue priorizar as necessidades de outros atores. Dessa forma, possivelmente, perdem-se oportunidades importantes para sua contribuição na implementação de políticas públicas, no que tange a gestão financeira do país.

Apresenta-se, a seguir, uma breve análise de inovação no setor público sob a ótica das características e atributos propostos pelo Klering e Andrade (2006):

a) Introdução de mudanças, qualitativas e quantitativas, em relação às práticas anteriores: uma vez que os serviços de TIC, no mínimo, promovem a revisão dos processos e procedimentos, contribuem, para melhorar quantitativa e/ou qualitativamente (este último sempre) o segmento de negócio em foco. Conforme o entrevistado, 
prévias eram geradas em papel. Atualmente o seu processo de emissão não só dispensa a geração de prévias em papel como também permite ao Tesouro alterar as formas de consultar e conferir os valores das consolidações contábeis tornando o processo de emissão mais ágil e confiável".

b) Credibilidade pública: todos serviços de TIC possuem, das instituições envolvidas, uma efetiva importância e visibilidade interna e oferece uma pronta resposta a demandas do público-alvo. Nas palavras de um dos entrevistados,

"Todas instituições usam o SIAFI. Há um reconhecimento da importância e segurança no serviço prestado, seja no setor público ou privado, dentro e fora do país, e pela sociedade. Quando há escândalo envolvendo recurso público, o SIAFI é uma referência para buscar o registro para comprovação".

Nas palavras de um outro entrevistado,

“... oferece pronta resposta, ainda que o processo de automação seja encerrado por uma camada de "mistério" (que são as regras de negócio, os algoritmos e métodos empregados internamente) pelos sistemas desenvolvidos e que não podem ser visualizados facilmente por um usuário não especializado".

c) Accountability: os serviços de TIC têm suas contas apresentadas para os respectivos clientes. Os contratos e as contas são públicos, passíveis de serem auditados a qualquer momento. Porém, existem serviços cujo controle é feito, ainda em nível global, nesses casos não há possibilidade de ter informações de um serviço em específico. Conforme destacado pelo entrevistado,

\footnotetext{
"Pode ter ou não ter. Por ser um processo complexo, caso seja mal executado, oferece condições de haver extrapolação de custos ou permitir desvios intencionais de recursos. Processos estruturados de desenvolvimento (baseados em boas práticas como o PMBOK e/ou CMM) dão condições de que haja maior previsibilidade e visibilidade dos custos incorridos".
}

Em relação a accountability dos projetos e serviços públicos que envolvem recursos do governo Federal, os serviços de TIC pesquisados contribuem para a visibilidade destes, na medida em que toda execução orçamentária e financeira destes estão contabilizados no SIAFI Operacional e apresentadas à sociedade no BGU e nos balancetes publicados no Portal SIAFI e Portal da Transparência. 
d) Compliance: os serviços de TIC estão em conformidade com leis, normas e instruções normativas de órgãos de regulamentação, conforme os requisitos estabelecidos pelo cliente. Além disso, todas as ações do prestador e dos clientes, conforme destacado pelo entrevistado,

“... o SERPRO, por força de respectiva vinculação ao governo, é obrigado a cumprir todos os ritos processuais e os cumpre. Um exemplo é o processo de compras, que obedece aos preceitos da Lei 8.666".

\section{e) Desenvolvimento de tecnologia e responsabilidade na utilização de} recursos e oportunidades: praticamente em todas as entrevistas foram citadas que os serviços de TIC pesquisados contribuem para melhorar a gestão de recursos sociais, com a criação ou não de novas tecnologias, desenvolvendo novas habilidades, através das revisões de processos que precede a automação, remodelando os procedimentos empregados. Com relação aos critérios de ética, de correção e de justiça, conforme citado na entrevista,

\footnotetext{
“... isto não é, exatamente, o papel do prestador de serviços, que tem como dever implementar aquilo que determina o contratante. Claro, dentro da condição em que o prestador pode influenciar, estes critérios são considerados no desenvolvimento".
}

f) Articulação entre governos de um mesmo nível: quase que a totalidade dos entrevistados responderam afirmativamente, considerando que a padronização dos procedimentos e instrumentos de execução orçamentária e financeira contribui para melhoria na comunicação e na busca de soluções conjunta entre governos de mesmo nível. Como exemplo, foram citados os seminários de contabilidade realizados periodicamente, onde o principal foco de discussão é o SIAFI. Também, foi citado como exemplo de solução conjunta, a premente adoção de contabilidade internacional no país, e mais uma vez, a atenção dos especialistas envolvidos está voltada para a evolução do SIAFI para contemplar as novas regras. Segundo entrevistado,

"O SIAFI é uma referência mundial. O seu modelo foi copiado por vários países e foi citado como um exemplo de instrumento de gestão financeira pela ONU onde foi apresentado no ano de 2005". 
g) Articulação entre governos de diferentes níveis: os entrevistados apontaram que estados e municípios possuem legislações próprias no segmento orçamentário e financeiro. Apesar disso, eles entendem que os serviços de TIC podem contribuir na articulação dos gestores das três esferas do governo através das funcionalidades disponibilizadas, principalmente, no SIAFI Operacional e no SIAFI Gerencial que permitem, por exemplo, o acompanhamento das transferências de recursos do Fundo de Participação dos Estados (FPM) e, Fundo de Participação dos Municípios (FPE) e outras transferências do Governo Federal para os estados e municípios. Outro exemplo é o acompanhamento dos convênios firmados pelos estados e municípios pela STN, quando o Governo Federal aparece como um fiador. Também foi citado que os especialistas da STN (da contabilidade, área financeira etc) são convidados pelos representantes dos estados e municípios para falar sobre legislações, normas, procedimentos e sobre o SIAFI, neste ultimo caso, muitas vezes os técnicos do SERPRO acompanham para apoiar o cliente na sua especialidade.

h) Consolidação e ampliação do diálogo com a sociedade civil: neste campo, o SIAFI proporciona uma fração pequena daquilo que poderia fazer considerando o universo de dados e as possibilidades de geração de informações acessíveis e úteis para sociedade. Existem serviços que disponibilizam informações para os cidadãos nos portais SIAFI e STN, mas em função do que foi mencionado anteriormente, os entrevistados entendem que não é efetivo. Existe um mínimo de funcionalidades que diretamente beneficiam e permite articulação com o cidadão, por exemplo, o Guia de Recolhimento na internet, depósitos de auxílio à saúde. Vale ressaltar que os dados do SIAFI alimentam diversos sítios do Governo que possibilitam acesso pelo cidadão, com Portal da Transparência.

i) Articulação com diferentes setores sociais, com diferentes atores, grupos, coletivos e segmentos sociais: da mesma forma que no item anterior, o SIAFI proporciona uma fração pequena daquilo que poderia fazer considerando o universo de dados e as possibilidades de geração de informações acessíveis e úteis para estes possíveis usuários. Para estes grupos, mais especializados, a linguagem contábil, possivelmente 
não seria impeditiva para o consumo da informação. Porém, os serviços direcionados para esta comunidade são os mesmo dos cidadãos, com exceção daqueles que conseguem habilitação para o uso do SIAFI Operacional ou outros serviços pela STN, conforme citado pelo entrevistado,

“... a governança sobre o que pode ou não ser disponibilizado para a sociedade é determinado pelo contratante". Segundo outro entrevistado, "Não há restrição formal. Hoje existe tramitando no Congresso um decreto público para liberar acesso a todos".

j) Transferibilidade: de acordo com os entrevistados, sem exceção, todos os serviços de TIC contribuíram para criar condições e tecnologias transferíveis e aproveitáveis em outras áreas, contextos, administrações e regiões. Diversas experiências de re-uso de soluções foram comentadas pelos entrevistados, dos quais estão destacados:

“...a partir do SIAFI foi desenvolvido e implantado o Sistema Integrado de Administração Financeira para Estados e Municípios (SIAFEM), com três escopos, para diversos estados e municípios; Apresentação do SIAFI para outros países; Inteligência e especialização de tecnologia e arquitetura de diversos serviços de TIC foram transferidas para outras soluções; melhoria contínua de processos e procedimentos ...".

“... A atual administração tem como missão o uso e internalização de código aberto, passível de re-uso por outras áreas da sociedade. O uso de frameworks abertos e de uma política de re-uso, levam a tranferibilidade".

k) Ampliação do número de beneficiários: os entrevistados concordam que os serviços de TIC geram impactos sobre, não apenas para o públicoalvo principal, mas também, sobre outros cidadãos e segmentos localizados ao redor, passíveis de serem sensibilizados e beneficiados de forma indireta. Todos os serviços pesquisados, na sua essência, tratam de contas públicas que viabilizam as políticas públicas, onde a sociedade é o maior beneficiário. Assim, toda sociedade tem interesse pela transparência dos gastos públicos.

I) Permeabilidade ao público alvo: entendendo-se como público-alvo, os usuários diretos dos serviços de TIC, estes atendem a este atributo. Vale ressaltar que a implantação de serviços precede de processos de capacitação, principalmente, quanto aos conceitos do negócio, em foco, e forma de operação das funcionalidades. Muitos serviços possui manuais eletrônicos e, em especial o SIAFI Operacional, possuem ambiente de 
ensino à distância e um ambiente denominado de SIAFI Educacional que disponibilizam recursos necessário para aprender a utilizar o serviço.

m) Simplificação da vida dos cidadãos: Como relatado anteriormente, os serviços de TIC pesquisados, de um modo geral, não atingem os cidadãos. Existe uma pequena parcela de funcionalidades que atendem a este atributo conforme exemplificado no item "h".

n) Incorporação de tecnologias facilitadoras da ação pública: as entrevistas apontam que os serviços de TIC são os principais indutores de utilização de novas tecnologias (como internet, sistemas de acompanhamento informatizado e outros) nos serviços públicos, o que contribuem para a eficiência e eficácia das ações públicas. Normalmente, a introdução de serviço de TIC é motivada pela busca de produtividade e qualidade dos serviços. Porém, conforme apontada pelos entrevistados, a garantia da eficiência e da efetividade das ações públicas depende de outros componentes como uma boa especificação dos requisitos de negócio, a atuação efetiva dos gestores e dos agentes responsáveis pelos serviços, a vontade política da efetivação dos serviços, garantindo os insumos necessários etc.

o) Fortalecimento do poder de gerenciamento para governos: os entrevistados foram unânimes em afirmar que os serviços de TIC pesquisados contribuem para fortalecer a capacidade de gerenciamento ao setor público, através do acesso aos dados e às informações de apoio à decisão e ao planejamento das ações públicas. Conforme um dos entrevistados: "... sem dúvida, o serviço prestado pelo SERPRO fortalece o gerenciamento do governo em praticamente todos os serviços prestados pela SUNAF ao Tesouro". Porém, os entrevistados ressaltaram que a qualidade das informações disponíveis não garante qualidade das decisões e nem a efetividade destas.

p) Enfoque sistêmico: os serviços de TIC são desenvolvidos com enfoque sistêmico, verificando-se as integrações com componentes internos e externos (por exemplo, demais serviços estruturantes do Governo Federal ou outros serviços de uso interno dos clientes). O enfoque sistêmico é uma das premissas principais que envolvem o desenvolvimento de software. Além disso, são disponibilizados funcionalidades alternativas os 
públicos alvos, considerando a sua especificidade e diversidade, como mencionada pelo entrevistado: “... no $\mathrm{CPR}^{19}$, alma do sistema, tem opção de uso integral ou parcial, baseado no fluxo da execução da receita e despesa do Governo Federal, envolvendo sistemas externos (SIASG, $\mathrm{SVPC}^{20}$ e outros) e outros subsistemas do SIAFI, de forma integrada".

A partir do Quadro 16, foi elaborado o Quadro 17 para obter uma visão consolidada do grau de aderência dos serviços de TIC aos atributos de inovação em gestão pública.

\begin{tabular}{|c|c|c|c|c|c|c|}
\hline \multirow{3}{*}{ Serviços } & \multicolumn{6}{|c|}{ Grau de Aderência aos atributos } \\
\hline & \multicolumn{2}{|c|}{ Alta } & \multicolumn{2}{|c|}{ Média } & \multicolumn{2}{|c|}{ Baixa } \\
\hline & Qdade & $\%$ & Qdade & $\%$ & Qdade & $\%$ \\
\hline SIAFI Operacional & 11 & 64,7 & 2 & 11,8 & 4 & 23,5 \\
\hline Sistema de Mensageria do TN & 11 & 73,3 & 1 & 6,7 & 3 & 20,0 \\
\hline Dívida Ativa do Tesouro & 11 & 73,3 & 1 & 6,7 & 3 & 20,0 \\
\hline Dívida Pública Interna & 11 & 73,3 & 1 & 6,7 & 3 & 20,0 \\
\hline Portal SIAFI & 6 & 42,9 & 2 & 14,3 & 6 & 42,9 \\
\hline Portal Tesouro & 9 & 60,0 & 6 & 40,0 & - & - \\
\hline DW Sintese & 13 & 81,3 & 2 & 12,5 & 1 & 6,3 \\
\hline DW Pagamento Efetivo & 12 & 75,5 & - & & 4 & 25,0 \\
\hline DW BGU & 12 & 75,5 & - & & 4 & 25,0 \\
\hline SIAFI Gerencial & 12 & 75,5 & - & & 4 & 25,0 \\
\hline Portal SIAFI & 12 & 75,5 & - & & 4 & 25,0 \\
\hline Média do grau de aderência & 10,9 & 69,9 & 1,4 & 9,0 & 3,3 & 21,1 \\
\hline
\end{tabular}

Quadro 17 - Grau de aderência dos serviços de TIC aos atributos de inovação em gestão pública

Fonte: Elaboração da autora.

Visando evitar distorções nos valores não foram considerados, no Quadro 17 , os atributos foram classificados como não aplicáveis aos serviços, conforme ilustrado no Quadro 16.

O Quadro 17 apresenta uma imagem bastante satisfatória de alta aderência dos serviços aos atributos de inovação em gestão pública, com $69,9 \%$ dos itens classificados nesta categoria. Somando os de alta e média, o percentual sobe para $78,9 \%$. Este resultado pode estar associado, diretamente, às competências do cliente e do prestador mobilizadas para implementação das características técnicas para incorporar as características finais dos serviços.

\footnotetext{
${ }^{19}$ O CPR - Cotas a Pagar e a Receber é um dos subsistemas do SIAFI Operacional.

20 Sistema de Viagens e Prestação de Contas
} 


\subsection{Processo de Gestão da Inovação}

A visão da SUNAF, o principal componente estratégico, é "Líder em solução de Tecnologia da Informação e Comunicação para gestão das finanças públicas". Para tanto, adota como missão "Prover e integrar soluções em Tecnologia da Informação e Comunicação para o êxito da gestão da administração orçamentária, financeira, patrimonial, da dívida e haveres públicos e da governança do estado para o benefício da sociedade", tendo como sua força motriz a capacidade de inovar e efetivar as entregas de serviços no prazo estabelecido com a qualidade contratada (SERPRO, 2009a). Estes componentes são extensões dos componentes estratégicos do SERPRO e refletem o valor da inovação dos serviços desenvolvidos e implementados, principalmente através do uso de TIC.

Porém, nem o Plano Diretor de Informática (PDTI), nem o modelo de negócio aponta para um modelo específico de gestão da inovação em serviços de TIC, sequer referenciam diretamente a palavra "inovação". Estes instrumentos estratégicos fazem referências aos processos corporativos (PSDS, PGPS, PSGS, PSS etc) e aos direcionamentos tecnológicos que focam a gestão dos serviços de TIC para uso de melhores práticas, padronização, qualidade, produtividade, re-uso, compartilhamento e cooperação, prospecção e internalização de novas tecnologias, orientações para aplicação de tecnologias etc.

Desta forma, as práticas apontadas nas entrevistas que visam, de alguma forma, a gestão da inovação em serviços estão relacionadas aos processos corporativos que orientam a formalização das informações sobre os serviços e o compartilhamento do aprendizado entre as equipes. Dentre os processos, dois foram citados pelos entrevistados como principais orientadores pra formalização e compartilhamento das informações: i) PSDS, foca os produtos e serviços relativos ao desenvolvimento de software (denominados de artefatos); ii) PGPS, foca informações relativas ao planejamento, execução, acompanhamento e fechamento do projeto.

A implantação destes processos ocorreu gradativamente ao longo dos últimos dez anos, implementam inovações radicais nos processos de desenvolvimento e produção dos serviços, em diversos segmentos: procedimentos, técnicas, ferramentas, organização, papéis dos atores etc. A mudança exigiu o 
estabelecimento de uma nova cultura organizacional e a sua institucionalização acontece de forma lenta, principalmente, por exigir novos conhecimentos, habilidades e atitudes dos colaboradores. Além disso, registra-se a existência de diversos serviços que foram gerados antes da institucionalização dos processos, como exemplo, SIAFI Operacional. A adequação das novas práticas aos serviços legados é muito difícil e lenta, como acontece com o SIAFI Operacional que possui cerca de hum mil e cem funcionalidades (transações), no seu menu de opções, implementados ao longo dos vinte e dois anos de sua existência. As documentações destes serviços, em sua maioria, até hoje não estão totalmente resgatadas. O processo de aprendizado sobre os serviços entre colaboradores da equipe acontece, principalmente, no trabalho de repasse de conhecimento corpo-acorpo com especialistas, através de treinamentos estruturado, tendo como instrutor um especialista sobre cada assunto e, quando existe, através da documentação existente. Conforme citado pelo entrevistado,

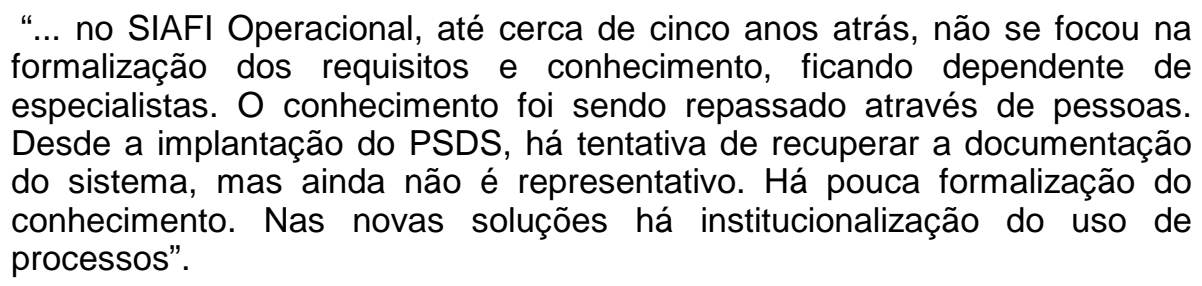

Quanto ao aprendizado entre diferentes equipes, nota-se que o problema agrava. De acordo com o entrevistado,

\footnotetext{
“...não há compartilhamento sistemático das soluções obtidas entre diferentes grupos. As dificuldades entre o que se quer e o que se obtém, no que diz respeito às práticas de Gerenciamento do Conhecimento, estão presentes na empresa e podem ser encontradas também na SUNAF".
}

Uma das razões está na questão da propriedade sobre a solução desenvolvida, em parceria com o cliente, que envolvem informações sobre o negócio e às regras de negócio. O aprendizado sobre a tecnologia (uso do software e hardware, arquitetura, topologia etc) é passível de ser repassado, porém, isso não acontece com a freqüência suficiente para ser considerado como uma prática da empresa. 


\section{CONCLUSÕES}

Esta pesquisa foi norteada pelo objetivo de identificar e caracterizar o processo de inovação em serviços de TIC numa unidade de negócio de uma empresa pública, tendo a SUNAF como um estudo de caso. Destaca-se que a SUNAF atua especificamente no segmento de TIC onde a tecnologia é um dos principais impulsionadores de inovações em serviços.

A pesquisa focou as inovações em produto, com base nos serviços de TIC, implementados pela SUNAF para os seus clientes no segmento financeiro do Governo Federal, com mais significativos em termos de previsão de receitas para o exercício de 2009. Com exceção de um serviço que implementou inovação por melhoria, todos os demais serviços pesquisados implementaram inovações radicais, envolvendo criação de um novo conjunto de características de serviços com adoção de novas tecnologias, onde no núcleo da motivação, na maioria dos serviços, está a busca pela eficiência e eficácia da gestão financeira para viabilização de políticas públicas, seja em nível de planejamento, execução ou auditoria.

Nota-se uma crescente preocupação com a integração entre os serviços públicos, o que contribui para melhoria da qualidade dos dados e dos próprios serviços, possibilitando atuação articulada e integrada dos atores de diferentes entidades do setor público. Esta realidade demanda o uso de tecnologias específicas de integração. Antes os sistemas focavam em automatizar os serviços operacionais de um segmento específico; atualmente, com foco na integração, exige-se maior especialização do prestador do serviço, não só em tecnologias, mas também em conhecimento geral de diversos segmentos que afetam a área financeira, o que envolve uma gama maior de conhecimento.

A preocupação em fortalecer a capacidade de gerenciamento das finanças públicas, principalmente nos últimos anos, contribui para aumentar a demanda pelo desenvolvimento de sistemas de apoio a gestão, principalmente daqueles baseados em tecnologia especializada, como data warehouse, onde o gestor conta com funcionalidades que tornam o tratamento de dados flexível às suas necessidades de informação, sem dependência de especialista em desenvolvimento de software. Este fato pode estar associado às exigências da Lei de Responsabilidade Fiscal (LRF), de 2000, e a maior atuação dos controles externos e auditorias. 
Os serviços de TIC pesquisados, na sua maioria, podem ser classificados como Serviços Intensivos em Conhecimentos (SICs). O desenvolvimento destes é realizado em parceria, cliente e SUNAF, desde a concepção, especificação, implementação e homologação, até a implantação. As fases de concepção e especificação envolvem atividades intensivas em repasse e troca de conhecimentos técnicos e administrativos sobre o negócio. Dessa forma, nota-se uma forte tendência para um cenário onde os analistas e os gestores da SUNAF passam a ter domínio das regras de negócios implementadas nos serviços, específicas da administração financeira do Governo Federal, tal qual o cliente. Por outro lado, o cliente também passa a ter mais conhecimento sobre as tecnologias aplicadas e a arquitetura do serviço. A cada interação, estes atores passam a acumular mais competências, capacitando-os a contribuir para impulsionar inovações em serviços. Assim, confirma-se que os SICs são intensivos em inovações, que podem ser direcionadas para o aumento de eficiência dos processos de negócios e de transferência de conhecimento, com possibilidade de geração de novos conhecimentos. Esta qualificação, tanto do cliente como do prestador, acaba influenciando, também, o mercado que procura se especializar cada vez mais para fornecer serviços de tecnologia para este segmento.

Com o advento da internet e a disponibilização de serviços públicos nesta tecnologia, há uma forte tendência de aumento de gama de ofertas e demandas de serviços destinados ao público em geral. Mais uma vez a tecnologia pode apoiar nesta direção, pois existem serviços nativos em diversas tecnologias, como data warehouse, que permite publicação direta da informação gerada, como possibilidade de entregar funcionalidade para tratamento de informações pelo público (formatação, seleção, consolidação etc).

Ao analisar os serviços de TIC da SUNAF sob a luz de uma abordagem sobre inovação no setor público, a pesquisa revelou a relevância de avaliação destes sob a perspectiva dos valores públicos agregados, no seu sentido amplo, considerando novos aspectos, os processos, os atores, novos sentidos e significados do serviço gerado, bem como os impactos sociais decorrentes. Os serviços de TIC sob esta perspectiva, em geral, apresentam-se com grau de conformidade satisfatório para maioria dos atributos.

Por outro lado, esta análise revelou uma questão que merece atenção pelos demandantes de serviços e pelo fornecedor, qual seja a da baixa aderência aos requisitos relativos à contribuição dos serviços para articulação entre: i) o governos 
de diferentes níveis; ii) governo e sociedade civil; iii) governo e diferentes setores sociais; iv) governo e diferentes atores, grupos, coletivos e segmentos sociais.

Os serviços, na sua maioria, estão destinados aos agentes e aos gestores responsáveis pela execução orçamentária e financeira do Governo Federal. Aqueles destinados aos estados e municípios estão focados no gerenciamento das transferências dos recursos federais para essas esferas e no controle dos convênios, em que o Governo Federal é apontado como avalista da transação. $O$ conhecimento acumulado, pela STN e pela SUNAF, a partir da implementação dos serviços pesquisados, pode transformar-se em importantes contribuições para inovações em serviços nas esferas estaduais e municipais.

Em relação à sociedade e outros setores, os serviços proporcionam um reduzido número de ofertas, considerando o universo de dados e as possibilidades de geração de informações acessíveis e úteis para este público. A simples disponibilização das informações, fortemente contábil, sem um tratamento adequado para a sociedade serão de pouca utilidade, sendo impeditivo para o seu consumo.

Em relação ao atendimento às demandas de diversos públicos, vale destacar que os clientes da SUNAF possuem, como todos os órgãos públicos, um volume de orçamento que não cabem todos os gastos desejados. Além disso, não possuem especialistas dedicadas à especificação e homologação de novos serviços. Assim, os clientes são obrigados a priorizar os serviços para o qual os recursos serão destinados. No caso da STN, por exemplo, dada a criticidade do tema, a prioridade acaba sendo destinada aos serviços ligados diretamente à execução e o gerenciamento das finanças públicas do Governo Federal, em detrimento do atendimento às demandas específicas de um determinado órgão. Além disso, as dificuldades envolvidas neste atendimento podem estar relacionadas ao fator político, à complexidade e tensões relacionadas à inclusão de novos atores e à adoção de ações interorganizacionais.

No que tange ao atributo "Simplificação da vida dos cidadãos", observou-se que, possivelmente pelas mesmas razões apresentadas anteriormente, quase a totalidade dos serviços de TIC não obteve atenção para envidar agregar este valor ao serviço ofertado.

Na pesquisa, os serviços revelaram-se como indutores de novos modelos de provisão de bens ou serviço para o setor público, principalmente na introdução de novas tecnologias. Dentre estes modelos destacam-se: serviços centralizados on- 
line (na implantação do SIAFI Operacional, por exemplo), comunicação direta com cidadão (serviço de auxílio à saúde, por exemplo); serviços via internet (portais, por exemplo); serviços de extração e transferência de dados; integração de serviços intraorganizacionais (integração SIAFI-SIASG no CPR, por exemplo); monitoração integrada ao serviço de faturamento (Serviço de Mensageria do Tesouro Nacional, por exemplo), modelo de disponibilização de "códigos livres" (aplicações e funcionalidades desenvolvidas em software livre) para outros órgãos etc.

Apesar deste cenário bastante propício às inovações em serviços e, por conseqüência, a realização de novos negócios, a SUNAF não possui um modelo de negócio voltado ao gerenciamento da inovação em serviços, reduzindo às práticas definidas pelos processos corporativos e ao direcionamento tecnológico. A inovação não é tratada formal e estrategicamente na unidade apesar de ser citada na força motriz como componentes estratégicos da superintendência.

A partir da presente pesquisa, entende-se que a implementação de um modelo de inovação que integre e alinhe o gerenciamento do modelo de negócio (mudança na proposição de valor agregado aos serviços, na forma de entregar os serviços e no público alvo dos serviços) e a inovação tecnológica (mudança em serviços, em processos para entrega dos serviços e na infra-estrutura que fornece suporte a esses serviços e processos) da empresa faz-se necessário e urgente para gerenciamento efetivo das inovações em serviços em TIC. A concepção de estratégias inovadoras em serviços pode transformá-los em principais indutores de desenvolvimento econômico da empresa.

No desenvolvimento do modelo de inovação em serviço deve-se reservar uma atenção especial para captação, desenvolvimento e manutenção do quadro de especialistas, em diversos segmentos de tecnologias, processos e negócios. Esses especialistas são um dos fatores críticos de sucesso em inovação em SICs. Tratando-se de uma empresa pública, o tema é bastante crítico e controverso e, desta forma, sugere-se uma pesquisa futura para investigar as práticas para o gerenciamento eficaz do quadro de especialistas em TIC que favoreçam a implementação de inovações em serviços de TIC, em uma empresa pública.

Em relação à gestão da SUNAF, destacam-se contribuições práticas para iniciar o gerenciamento das inovações em serviços na unidade, quais sejam: i) implementação de um modelo inicial de gestão da inovação, integrando o modelo de negócio e as tecnologias aplicadas nos serviços e as definidas no direcionamento tecnológico; ii) estabelecimento de metas a curto, médio e longo 
prazo para implementação de inovações nos serviços sob gestão da unidade; iii) nos projetos de sistemas de informações, analisar e categorizar os requisitos sob a luz da abordagem sobre inovação no setor público e a abordagem além tecnicista; iv) criar um check list para avaliar a incorporação de características essenciais para viabilizar inovação em serviços de TIC; v) implementar melhorias para o as práticas de gestão do conhecimento da unidade, de modo a favorecer o aprendizado individual e coletivo dentro da unidade e com demais unidades.

Esta pesquisa focou os principais serviços da SUNAF, considerando as suas características e as práticas corporativas e as específicas desta superintendência. Porém, as teorias aplicadas, nesta pesquisa, parecem ser aplicáveis a todos os serviços de TIC desenvolvidos e produzidos por demais unidades de negócio do SERPRO. Assim, entre as contribuições a serem desenvolvidas por estudos futuros, insere-se a extensão deste estudo para as demais unidades de negócios. O resultado deste estudo pode tornar-se um importante insumo para revisão do modelo de negócio e de tecnologia para, posteriormente, implementação de modelo corporativo de inovação em serviços para a empresa SERPRO. 


\section{REFERÊNCIAS}

AMBRÓSIO, Aluísio; AMBRÓSIO, Vicente. A Matriz BCG passo a passo. Revista da ESPM, São Paulo, v.12, ano II, 2005.

ANDRADE, Jackeline A. 0 processo de inovação nas organizações públicas: integrando conceitos às práticas. In: ENCONTRO ANUAL DA ANPAD, 25., Campinas. 2001, Anais. Capinas: Anpad, 2001.

BAUER, Martin W.; GASKELL, George. A construção do corpus: princípio para a Coleta de dados qualitativos. In: BAUER, Martin W e AORTS, Bas. Pesquisa qualitativa com texto, imagem e som: um manual prático. 4. ed. Petrópolis: Editora Vozes, 2005. cap. 2.

BERNARDES, R.; KALLUP, A. A emergência dos serviços intensivos em conhecimento no Brasil. In: BERNARDES, R.; ANDREASSI, T. (Org.). Inovação em serviços intensivos em conhecimento. São Paulo: Saraiva, 2007. cap. 5.

CRESWELL, John W. Projeto de Pesquisa: métodos qualitativo, quantitativo e misto. 2. ed. Porto Alegre: Artmed\&Bookman, 2007. p. 89-229.

FARAH, M. F. S. Governo local, políticas públicas e novas formas de gestão pública no Brasil. Organizações e Sociedade. V.7, n. 17, jan./abr., 2000.

FARAH, M. F. S. Inovação e o governo local no Brasil contemporâneo. In: JACOBI, P.; PINHO, J. A. (Org.). Inovação no campo da gestão pública local: novos desafios, novos patamares. Rio de Janeiro: FGV, 2006. p. 41-75.

FREIRE, C. T. Um estudo sobre os serviços intensivos em conhecimento no Brasil. In: NEGRI, J. A.; KUBOTA, L. C. (Org.). Estrutura e dinâmica do setor de serviços no Brasil. Brasília: IPEA, 2006. p.107-131.

GALLOUJ, F. Economia da inovação: um balanço dos debates recentes. In: BERNARDES, R.; ANDREASSI, T. (Org.). Inovação em serviços intensivos em conhecimento. São Paulo: Saraiva, 2007. cap. 1.

GIL, Antônio C. Como elaborar projetos de pesquisa. 3. ed. São Paulo: Editora Atlas, 1996.

INSTITUTO BRASILEIRO DE GEOGRAFIA E ESTATÍSTICASS. Contas anuais trimestrais 2008. Disponível em <http:://www.ibge.gov.Br>. Acesso em: janeiro de 2009.

GODOY, Arlinda S. Introdução à pesquisa qualitativa e suas possibilidades. Revista 
de Administração de Empresas, São Paulo, V.35, n. 2, p.57-63, mar./abr.1995.

INSTUTO BRASILEIRO DE GEOGRAFIA E ESTATÍSTICA. Contas anuais trimestrais 2008. Disponível em <HTTP://www.ibge.gov.br>. Acesso em: dia janeiro de 2009.

KON, Anita. Serviços de conhecimento: uma agenda para indução do desenvolvimento econômico. In: BERNARDES, R.; ANDREASSI, T. (Org.). Inovação em serviços intensivos em conhecimento. São Paulo: Saraiva, 2007. cap. 4 .

KLERING, L. R.; ANDRADE, J. A. Inovação na gestão pública: compreensão do conceito a partir da teoria e da prática. In: JACOBI, P.; PINHO, J. A. (Org.). Inovação no campo da gestão pública local: novos desafios, novos patamares. Rio de Janeiro: FGV, 2006. cap.77-97.

KUBOTA, L. C. A inovação Tecnológica das firmas de serviços no Brasil. In: NEGRI, J. A.; KUBOTA, L. C. (Org.). Estrutura e dinâmica do setor de serviços no Brasil. Brasília: IPEA, 2006. p.35-72.

KUBOTA, L. C. A contribuição dos SICs para a inovação tecnológica das firmas de serviços. In: BERNARDES, R.; ANDREASSI, T. (Org.). Inovação em serviços intensivos em conhecimento. São Paulo: Saraiva, 2007. cap. 8.

MILES, lan. Serviços e Inovação na Europa. In: BERNARDES, R.; ANDREASSI, T. (Org.). Inovação em serviços intensivos em conhecimento. São Paulo: Saraiva, 2007. cap. 3.

MINISTÉRIO DO PLANEJAMENTO, ORÇAMENTO E GESTÃO. Estratégia geral de TI 2008. Dez.2008.

MOTTA, Paulo Roberto, Transformação organizacional. Rio de Janeiro: Qualitymark, 1999.

YIN, R. K. Estudo de Caso: planejamento e métodos. 3. ed. Porto Alegre: Bookman, 2005. p.19-170.

NETO, Carvalho. Como fazer uma monografia. $1^{\text {a }}$ ed. Fortaleza: Texto \& Contexto Editora, 2007.

SERPRO. Home page. Disponível em <http://www.SERPRO.gov.br/instituicao/quem/>. Acesso em: 19 abr. 2009a. 
Programa SERPRO de gerenciamento de projetos - PSGP. Disponível em <http://coeep.SERPROnet.SERPRO/pgps/processos-e-projetos $>$. Acesso em: 19 abr.2009b.

Processo SERPRO de desenvolvimento de soluções - PSDS. Disponível em <http://cetec.SERPROnet.SERPRO/psmds/psds>. Acesso em: 19 abr.2009c.

Programa SERPRO de gerenciamento de serviços de tecnologia da
informação e e comunicação - PSGTI. Disponível em
<http://cetec.SERPROnet.SERPRO/psgti/arquivos>. Acesso em: 19 abr.2009d.

Programa SERPRO de segurança - PSS. Disponível em <http://cetec.SERPROnet.SERPRO/segur/pss>. Acesso em: 19 abr.2009e.

Plano diretor de tecnologia da informação - PDTI. Mai.2009f.

STN. Home page. Disponível em <http://www.tesouro.fazenda.gov.br/instituicao_tesouro/index.asp>. Acesso em: 10 mai. 2009.

VARGAS, E. R. Estratégia e inovação em serviços. Organizações \& Sociedade, v.14, p.17-27, 2007.

Vargas, E. R. Inovação em serviços: casos de hospitais Porto-Alegrenses. 2002. 113 f. Dissertação (Mestrado em Administração) - Universidade Federal de Porto Alegre, Porto Alegre, 2002.

VARGAS, E. R.; ZAWISLAK, P. A. Inovação em serviços no paradigma da economia do aprendizado: a pertinência de uma dimensão espacial na abordagem dos sistemas de inovação. Revista de Administração Contemporânea, Rio de Janeiro, V.10, n. 1, p.139-159, janeiro. 2006.

VARGAS, E. R.; ZAWISLAK, P. A. Abordagem funcional e as lógicas de inovação em serviços: desenvolvendo uma análise não-tecnicista da evolução do serviço hospitalar. Revista de Ciências da Administração, Florianópolis, V.07, n. 14, p.177-197, dezembro. 2005. 


\title{
APÊNDICE A - ROTEIRO DE ENTREVISTA
}

\author{
UNIVERSIDADE DE BRASÍLIA - UNB
}

Faculdade de Economia, Administração, Contabilidade e Ciência da Informação e Documentação - FACE

Programa de Pós-graduação em Administração - PPGA

\section{ROTEIRO DE ENTREVISTA, SEMI-ESTRUTURADA, COM ESPECIALISTAS DA SUNAF}

\section{BLOCO 1 - IDENTIFICAÇÃO DO ENTREVISTADO}

1. Nome

2. Função:

3. Tempo de atuação:

\begin{tabular}{|c|c|c|c|}
\hline TIC & TIC Governo & Gerência & SUNAF \\
\hline & & & \\
\hline
\end{tabular}

4. Trajetória profissional no setor de serviço em TIC (formação, papéis exercidos, experiências, etc)

\section{BLOCO 2 - ORIGEM DO SERVIÇO DE TIC}

5. Qual órgão patrocinador e cliente do serviço de TIC?

6. Qual entidade (cliente ou SERPRO) identificou a possibilidade ou a necessidade do serviço?

7. Quais foram as principais motivações para o desenvolvimento do serviço de TIC?

8. Quais foram os principais objetivos identificados para a implementação do serviço?

9. Existem políticas públicas ou programas governamentais que influenciem a implementação do serviço de TIC?

10. Qual é o publico alvo do serviço? 


\section{BLOCO 3 - CARACTERIZAÇÃO DA INOVAÇÃO EM SERVIÇO DE TIC}

1. Quais são as características de serviços, os valores de uso, as utilidades fornecidas ao cliente pelo serviço de TIC?

2. Quais são características técnicas materiais ou imateriais e do processo, isto é, os técnicos (métodos, sistemas técnicos de back office ou de front office) mobilizados para produzir as propriedades de serviços?

- Quais foram novidades tecnológicas introduzidas pela solução adotada?

- Como se deu opção pela infra-estrutura tecnológicas utilizadas no serviço de TIC?

- Quais são os aspectos mais relevantes da solução adotada?

- A tecnologia é aplicada com o objetivo de aprimorar a entrega dos serviços prestados, norteado pela melhoria da eficiência, melhoria da qualidade e/ou geração de novos serviços?

3. Quais foram competências, do cliente e do SERPRO, mobilizadas na implementação e na implantação do serviço?

4. Em sua opinião, os principais objetivos foram alcançados com a implantação do serviço? Justifique.

5. Em sua opinião, quais são os principais benefícios obtidos com a implantação do serviço de TIC, para os principais stakeholders: patrocinador, cliente, usuários, SERPRO e a sociedade?

6. Em sua opinião, quais foram os principais fatores facilitadores e dificultadores na implementação do serviço de TIC?

\section{BLOCO 4 - PRÁTICAS INOVADORAS DE GESTÃO PÚBLICA - ATRIBUTOS DE INOVAÇÃO DO SERVIÇO DE TIC}

1. Introdução de mudanças, qualitativas e quantitativas, em relação às práticas anteriores: o serviço de TIC introduz novos modos ou modelos de provisão de bens e serviços, ser capaz de mudar hábitos ou costumes de trabalho, desenvolver produtos e serviços, tanto novos, quanto renovar os antigos? Justifique 
2. Credibilidade pública: o serviço de TIC possui, das instituições envolvidas, uma efetiva importância e visibilidade interna e oferece pronta resposta a demandas do público-alvo? Justifique.

3. Accountability: o serviço de TIC tem suas contas e seu funcionamento apresentados de forma clara, objetiva e transparente aos seus apoiadores e à sociedade em geral, com prestações regulares de contas? Justifique.

4. Complice: o serviço de TIC está em conformidade com leis, normas e recomendações de órgão de regulamentação? Justifique.

5. Desenvolvimento de tecnologia e responsabilidade na utilização de recursos e oportunidades: o serviço de TIC contribui para melhorar a gestão de recursos sociais, criando novas tecnologias, desenvolvendo novas habilidades de ação, dentro de critérios de ética, correção e justiça? Justifique.

6. O serviço de TIC contribui, direta ou indiretamente, para:

- Articulação entre governos de um mesmo nível (melhorar a comunicação, interação e envolvimento e a busca de soluções conjuntas entre governo de mesmo nível, pela formação de parcerias, associações em redes de atuação conjunta, de grupos de município ou grupos de estado?) Justifique.

- Articulação entre governos de diferentes níveis (melhorar a comunicação, interação e envolvimento e a busca de soluções conjuntas entre governo de diferentes níveis, pela formação de parcerias para atuação conjunta, em que cada ente federativo cumpre determinado papel, como parte de um sistema ou de uma rede, visando alcançar objetivos comuns entre municípios e estados e a União)? Justifique.

- Consolidação e ampliação do diálogo com a sociedade civil (melhorar a comunicação, interação e envolvimento de uma comunidade, em relação a assuntos de seu interesse, criando uma maior "massa crítica" e consciência social, assim como maior responsabilidade pelas coisas públicas)? Justifique.

- Articulação com diferentes setores sociais (melhorar a comunicação, interação e envolvimento entre os diferentes setores e atores sociais: 0 setor público, o setor privado e o chamado "terceiro setor", em relação a demandas e assuntos de interesse real e potencial da sociedade, criando 
maior responsabilidade e solidariedade social, formulando e implementando soluções, principalmente via rede de ações)? Justifique.

- Articulação com diferentes atores, grupos, coletivos e segmentos sociais (melhorar a comunicação, interação e envolvimento de diferentes atores, grupos de interesse real e potencial da sociedade, criando maior responsabilidade social, engajamento cívico e solidariedade social, via atuação preferencial em redes)? Justifique.

7. Transferibilidade: o serviço de TIC contribui para criar condições e tecnologias transferíveis e aproveitáveis em outras áreas, contextos, administrações e regiões? Justifique.

8. Ampliação do número de beneficiários: o serviço de TIC gera impactos sobre, não apenas para o público-alvo principal, mas também, sobre outros cidadãos e segmentos localizados ao redor, passíveis de serem sensibilizados e beneficiados de forma indireta? Justifique.

9. Permeabilidade ao público alvo: o serviço de TIC contribui para aproximarse do público-alvo, com interface entendível e compreensível, suficientemente simples, informal e coerente com o modo de vida prevalente, para ser facilmente contatado, assimilado e adotado na vida cotidiana dos usuários? Justifique.

10. Simplificação da vida dos cidadãos: o serviço de TIC facilita e simplifica o acesso dos cidadãos a bens e serviços públicos e sociais; racionaliza ações, visando maior eficácia, sem desconsiderar aspectos de tradições, de afeições e de valores do público-alvo? Justifique.

11. Incorporação de tecnologias facilitadoras da ação pública $O$ serviço de TIC estimula a introdução de novas tecnologias (como internet, sistemas de acompanhamento informatizado e outros) que facilitem e tornem mais eficaz a ação pública, rompendo ou quebrando paradigmas de ação mais antigos e eficazes? Justifique.

12. Fortalecimento do poder de gerenciamento para governos: o serviço de TIC contribui para fortalecer e devolver capacidade de gerenciamento efetivo ao setor público; ao mesmo tempo em que delega ações, deve fortalecer a capacidade de planejar, definir estratégias amplas e gerais, visando articular melhor as ações de diferentes atores e setores da sociedade? Justifique. 
13. Enfoque sistêmico: o serviço de TIC tem enfoque sistêmico, em que as partes desempenham um papel integrativo para alcance de objetivos comuns; se aceita caminhos ou opções alternativas (em vez de lineares e únicas); considerando-se o sistema focado como contendo partes, e ao mesmo tempo, fazendo parte de um sistema maior; se aceita constantes prevenções, reavaliações e reajustes; enfatiza-se mais perspectivas dinâmicas e integrativas, do que estatísticas pontuais? Justifique.

14. O serviço de TIC introduz um novo modelo de provisão de bens ou serviço para o setor público? Justifique.

\section{BLOCO 5 - PRÁTICAS DE APRENDIZAGEM VISANDO INOVAÇÕES FUTURAS}

1. As competências e as inovações técnicas e organizacionais desenvolvidas na implementação do serviço de TIC (soluções técnicas inovadoras visando reutilização, novos padrões de qualidade, incorporação melhores práticas nos processos corporativos - gestão de projetos, engenharia de software, gerenciamento de serviços etc) foram absorvidas pela equipe e formalizadas de modo a viabilizar acesso às informações sobre o conhecimento adquirido, por

2. A inovação em serviço de TIC implementada contribui para a obtenção de novos clientes ou novos contratos com o mesmo cliente? Justifique. 